Wilson Alves Ferreira Júnior

\title{
Caracterização da ação molecular da Bunodosina 391, composto analgésico obtido da peçonha da anêmona Bunodosoma cangicum
}

Dissertação apresentada ao Programa de Pós-Graduação em Farmacologia do Instituto de Ciências Biomédicas da Universidade de São Paulo, para obtenção do Título de Mestre em Ciências.

São Paulo

2010 
Wilson Alves Ferreira Júnior

\section{Caracterização da ação molecular da Bunodosina 391, composto analgésico obtido da peçonha da anêmona \\ Bunodosoma cangicum}

Dissertação apresentada ao Programa de PósGraduação em Farmacologia do Instituto de Ciências Biomédicas da Universidade de São Paulo para obtenção do Título de Mestre em Ciências.

Área de concentração: Farmacologia

Orientadora: Profa. Dra. Yara Cury

São Paulo

2010 
DADOS DE CATALOGAÇÃO NA PUBLICAÇÃO (CIP)

Serviço de Biblioteca e Informação Biomédica do

Instituto de Ciências Biomédicas da Universidade de São Paulo

(C) reprodução total

Ferreira Junior, Wilson Alves.

Caracterização da ação molecular da Bunodosina 391, composto analgésico obtido da peçonha da anêmona Bunodosoma cangicum / Wilson Alves Ferreira Junior. -- São Paulo, 2010.

Orientador: Yara Cury.

Dissertação (Mestrado) - Universidade de São Paulo. Instituto de Ciências Biomédicas. Departamento de Farmacologia. Área de concentração: Farmacologia. Linha de pesquisa: Toxinas animais como ferramentas farmacológicas para o estudo das vias de sinalçização da dor e seu controle.

Versão do título para o inglês: Characterization of the molecular mechanisms involved in the analgesic effect of Bunodosina 391 (BDS 391) obtained from Bunodosoma cangicum sea anemone venom.

Descritores: 1. Toxinas animais 2. Anêmonas do mar 3. Atividade analgésica 4. Fisiopatologia da dor 5.Serotonima I. Cury, Yara II. Universidade de São Paulo. Instituto de Ciências Biomédicas.Programa de Pós-Graduação em Farmacológia III. Título. 
Candidato(a):

Título da Dissertação:

Orientador(a):
Wilson Alves Ferreira Junior.

Caracterização da ação molecular da Bunodosina 391, composto analgésico obtido da peçonha da anêmona Bunodosoma cangicum .

A Comissão Julgadora dos trabalhos de Defesa da Dissertação de Mestrado, em sessão pública realizada a ./...................................,
( ) Aprovado(a)
( ) Reprovado(a)

Examinador(a): Assinatura:

Nome:

Instituição:

Examinador(a): Assinatura:

Nome:

Instituição:

Presidente: Assinatura:

Nome:

Instituição: 


\section{Certificado}

Certificamos que o protocolo registrado sob $n^{\circ} \mathbf{1 1 5}$ nas fls. $\mathbf{6 2}$ do livro $\mathbf{0 2}$ para uso de animais em experimentação, sob a responsabilidade de Yara Cury, Coordenador(a) da Linha de pesquisa "Caracterização da ação molecular da bunodosina 391, composto analgésico obtido a partir da peçonha da anêmona bunodosoma cangicum" do qual participou(aram) o(s) alunos Wilson Alves Ferreira Júnior, Vanessa Pacciari Gutierres e os pesquisadores André Junqueira Zaharenko, Gisele Picolo, Merari de Fátima Ramires Ferrari, está de acordo com os Principios Éticos de Experimentação Animal adotado pelo Colégio Brasileiro de Experimentação Animal (COBEA) e foi aprovado pela COMISSÃO DE ÉTICA EM EXPERIMENTAÇÃO ANIMAL (CEEA) em 19.11.08, com validade de 3 anos.

São Paulo, 24 de novembro de 2008.

\section{Lethona.}

Prof. Dr. WOTHAN TAVARES DE LIMA Coordenador CEEA - ICB/USP

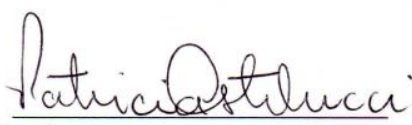

Profa. Dra. PATRÍCIA CASTELUCCI Secretária CEEA - ICB/USP 


\section{CERTIFICADO}

Certificamos que o Projeto intitulado "Caracterização da ação molecular da Bunodosina 391, composto analgésico obtido a partir da peçonha da anêmona Bunodosoma cangicum", protocolo $n^{\circ} 494 / 08$, sob a responsabilidade de Yara Cury e Wilson Alves Ferreira Júnior, está de acordo com os Princípios Éticos na Experimentação Animal adotado pelo Colégio Brasileiro de Experimentação Animal (COBEA), e foi aprovado pela COMISSÃO DE ÉTICA NO USO DE ANIMAIS DO INSTITUTO BUTANTAN (CEUAIB) em reunião de 11/06/2008.

We certify that the Research entitled "Characterisation of the molecular action of Bunodosine 391, an analgesic compound from the venom of the sea anemone Bunodosoma cangicum", protocol $n^{\circ} 494 / 08$, under the responsability of Yara Cury and Wilson Alves Ferreira Júnior, is in agreement with the Ethical Principles in Animal Research, adopted by the Brazilian College of Animal Experimentation, and was approved by the ETHICAL COMMITTEE FOR ANIMAL RESEARCH of BUTANTAN INSTITUTE in the meeting of $\underline{06 / 11 / 2008}$.

\begin{tabular}{|c|c|}
\hline $\begin{array}{c}\text { Vigência do Projeto: } \\
09 / 2008-08 / 2010\end{array}$ & $\mathbf{N}^{\circ}$ de animais/espécie \\
\hline & $117 /$ ratos Wistar \\
\hline
\end{tabular}

São Paulo, 19 de junho de 2008.

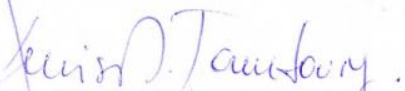

Dra. Denise V. Tambourgi

Presidente da CEUAIB

De acordo:

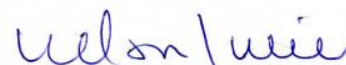

\. Otávio Azevedo Mercadante

Diretor do Instituto Butantan 
COMISSÃO DE ÉTICA NO USO DE ANIMAIS

INSTITUTO BUTANTAN

Av. Vital Brazil, 1500, CEP 05503-900, São Paulo, SP, Brazil Telefone: (55) (011) 3726-7222 ramal 2106 - Fax: (55) (011) 3726-1505

\section{CERTIFICADO}

Certificamos que o Projeto intitulado "Caracterização da ação da Bunodosina 391, composto analgésico obtido a partir da peçonha da anêmona Bunodosoma cangicum", protocolo $\mathrm{n}^{\circ}$ 494/08, sob a responsabilidade de Yara Cury e Wilson Alves Ferreira Júnior, está de acordo com os Princípios Éticos na Experimentação Animal adotado pela SOCIEDADE BRASILEIRA DE CIÊNCIA DE ANIMAIS DE LABORATÓRIO (SBCAL/cobea) e foi aprovado pela COMISSÃO DE ÉTICA NO USO DE ANIMAIS DO INSTITUTO BUTANTAN (CEUAIB) em reunião de 11/06/2008.

A CEUAIB autorizou as mudanças solicitadas pela pesquisadora, ou seja, alteração no prazo de vigência e do número total de animais para o projeto, em reunião de 04/03/2009.

We certify that the research entitled "Characterization of the molecular action of the Bunodosine 391, analgesic compound from the venom of the sea anemone Bunodosoma cangicum", protocol $\mathrm{n}^{\circ} 494 / 08$, under the responsibility of Yara Cury and Wilson Alves Ferreira Júnior is in agreement with the Ethical' Principles in Animal Research, adopted by the Brazilian Society of Laboratory Animal Science, and was approved by the ETHICAL COMMITTEE FOR ANIMAL RESEARCH of BUTANTAN INSTITUTE in the meeting of 11/06/2008.

\begin{tabular}{|c|c|}
\hline Vigência do Projeto: & $\mathbf{N}^{\circ}$ de animais/espécie \\
\hline 08/2008 a 07/2010 & Total: 113/Ratos Wistar \\
\hline Laboratório de Fisiopatologia & Total: 81 /camundongos Swiss/macho \\
\cline { 2 - 2 }
\end{tabular}

De acordo:

São Paulo, 05 de Março de 2009.

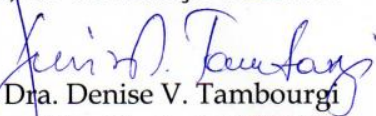
Dra. Denise V. Tambourgi

Dr. Otávio Azevedo Mercadante Diretor do Instituto Butantan 


\section{Ode to the nematocyst}

Wondrous little organelle of death;

O to know your mysteries.

A coiled harpoon of lightning speed,

Revealing species' histories.

Banana-shaped or ovoid,

Large or small, or spheres.

Measured in tens of microns,

Powerful microns of fear.

Forty thousand G's of force,

Drilling into flesh;

Bathed in a golden toxin,

Spiny hypodermic of death.

Designed to conquer prey or foe,

But if you longer linger,

Fascinating capsules of beauty,

These treasures of St. Inger.

.......................St. Inger, the Patron Saint of Marine Envenomation 


\section{Dedicatória}

Dedico este trabalho

Aos meus queridos pais, Wilson e $\mathcal{N i t i n h a}$

Por permitirem que eu sempre pudesse seguir o MEV caminho. Agradeço especialmente pelo respeito ao meu trabalho. Amos vocês.

Aos meus irmãos Juliano e Juliane

Por estarem sempre presentes. $\mathcal{E}$ agora as minhas sobrinhas Letícia e Natalya por trazerem mais alegria para nossa família. Vocês são muito importantes. 
Agradeço e dedico este trabalho,

\section{Aे Yara}

Muito obrigado pela confiança e amizade construída nesses 4 anos de Butantan. Agradeço também tođa a paciência e a maneira admirável que você consegue passar, aos seus alunos, o amor e seriedade necessária para fazer ciência de qualidade. Muito obrigado! 


\section{Aos meus amigos}

A maior conquista desta trajetória foi descobrir, no dia a dia, novos AMIGOS e que estes estarão sempre ao meu lado, incentivando, aplaudindo e principalmente mostrando meus erros. Adoro todos vocês.

Vanzinha, muito obrigado pelos ensinamentos, conselhos e as merecidas "puxadas de orelha". Você é um grande exemplo de dedicação e amor a arte de fazer ciência. A nossa número 1.

Van Gutcha, obrigado por me ensinar e pela importante participação neste trabalho. Muito obrigado por estar presente em todos os momentos. Você é muito querida. Te adoro!

Re Aoki, muito obrigado por fazer parte desta conquista, pelo carinho, incentivo... Muito obrigado a você e toda sua familia (Papai, Mamãe, Fe e Pinguinho). Adoro vocês...

Gi, obrigado por sua ajuda e amizade. Por ser a minha co-orientadora!

Pat, Re, Kiko, muito obrigado pela amizade e pelos bons momentos juntos... vocês fazem parte da família LEDS...

André, obrigado por sempre estar presente me apoiando. Sempre com tempo para discutir os resultados, dar conselhos... Muito obrigado pela grande amizade.

Aninha, muito obrigado por toda sua ajuda, você é queridíssima...

Jufiana (Cleide), procurando sempre aprender um pouquinfo com todos, porem ensinando muito para todos, vocêe é um grande exemplo... Muito obrigado Ju!

Luciana, obrigado pela amizade e por me ajudar sempre...

Fran, Nat, Lais e Cesar, muito obrigado pela amizade e toda ajuda...

Às novas colegas... Flavia, Paola e Eli, muito obrigado.

Aos novos colegas... Leandro, valeu pela amizade e seja bem vindo de volta ao grupo. Leandro Grecco, obrigado pela amizade...

Aos técnicos e amigos do LEDS... Sandra, Tânia e Claudemir, vocês são fundamentais para o nosso Laboratório. Muito obrigado! 
Pat Lacouth, Muito obrigado por ser sempre presente, por me apoiar em momentos difíceis... Te adoro! 


\section{Agradecimentos}

Ao Professor Dr. José Carlos de Freitas, do Laboratório de Farmacologia de Produtos $\mathcal{N}$ aturais Marinhos, IB-USP, por todo ensinamento. Obrigado por ajudar e disponibilizar seu laboratório, sempre que solicitado, para a realização da extração e purificação da peçonha.

Ao Prof. Dr. Katsufiro Konno, da Faculdade de Medicina Tropical, Vniversidade de Toyama, Japão, por toda ajuda com a caracterização estrutural do BDS 391.

Ao Prof. Dr. Jan Tytgat, da Faculdade de Ciências Farmacêuticas, Universidade Católica de Leuven, Bélgica, pela oportunidade de realizar um estagio em seu laboratório. Obrigado pelos ensinamentos de eletrofisiologia.

A Selma, Julieta e Celso do departamento de Pós-Graduação do ICB, por estarem sempre dispostos a resolver qualquer problema.

Aos alunos do Laboratório Especial de Dor e Sinalização do Instituto Butantan.

Aos funcionários da biblioteca do Instituto de Ciências Biomédicas da USP.

Ao Biotério Central do Instituto Butantan, pelo fornecimento dos animais.

Agradeço também à FAPESP pelo apoio financeiro. 


\section{RESUMO}

Ferreira Junior WA. Caracterização da ação molecular da Bunodosina 391, composto analgésico obtido da peçonha da anêmona Bunodosoma cangicum. [dissertação (Mestrado em Farmacologia)]. São Paulo: Instituto de Ciências Biomédicas da Universidade de São Paulo; 2010.

Substancias bioativas obtidas de venenos animais, podem interagir com diversos alvos farmacológicos, o que as tornam ferramentas importantes para o entendimento, por exemplo, dos mecanismos da dor e seu controle. As anêmonas do mar utilizam rico complexo protéico para capturar suas presas e se defender de predadores. A peçonha destes animais contem neurotoxinas (3-5 kDa), com ação em canais iônicos específicos e hemolisinas (18-20 kDa), que atuam formando poros em membranas. No entanto, pouco se conhece sobre a atividade biológica de substâncias de baixo peso molecular isoladas da peçonha destes animais. Recentemente, foi demonstrado que a Bunodosina 391 (BDS 391), um composto de baixo peso molecular isolado da peçonha da anêmona do mar Bunodosoma cangicum, acarreta aumento do limiar nociceptivo de ratos, quando avaliada no teste de pressão de patas. A molécula bioativa BDS 391 é um composto bromado de aproximadamente $400 \mathrm{Da}$, composta de um núcleo molecular semelhante a serotonina (5-HT), conectado, por meio de uma ligação peptídica, a uma histidina. Ensaios farmacológicos iniciais mostraram que a atividade do BDS 391 é mediada pela ativação de receptores serotoninérgicos e histaminérgicos e pela abertura de canais de potássio. É interessante observar que o BDS 391 apresenta similaridade estrutural a 5-HT e histamina, sendo esta ultima um derivado do aminoácido histidina, o que torna de especial interesse a detecção do efeito antinociceptivo periférico para este composto. Assim, o presente projeto de pesquisa visou caracterizar a ação antinociceptiva do BDS $391 \mathrm{em}$ modelos de nocicepção manifesta em camundongos e de hipernocicepção aguda e crônica em ratos e também ampliar a caracterização dos mecanismos envolvidos nesta ação, determinando. por meio de ensaios comportamentais, in vivo e de ensaios de "binding" e eletrofisiológicos, in vitro, os subtipos de receptores serotoninérgicos e de canais de potássio responsáveis pelo efeito antinociceptivo. Os resultados mostraram que o BDS $391(0.15-150 \mu \mathrm{M})$ foi capaz de inibir a resposta nociceptiva induzida pela injeção de formalina 1\%. Também foi observado que o composto BDS 391 apresenta efeito antinociceptivo em modelos de hiperalgesia induzida pela prostaglandina $\mathrm{E}_{2}$ ou pela constrição crônica do nervo isquiático. Os estudos farmacológicos evidenciaram que a ação do BDS 391 é mediada pela ativação dos receptores para serotonina do subtipo $5-\mathrm{HT}_{3}$. No entanto, resultados preliminares dos ensaios de ligação mostraram que o BDS 391 não é capaz de interferir com a ligação do antagonista seletivo deste receptor. Neste estudo, também foi confirmada, por ensaios de immunoblotting, que os subtipos de receptores $5-\mathrm{HT}_{1 \mathrm{a}}, 5-\mathrm{HT}_{2}$ e $5-\mathrm{HT}_{3}$ estão expressos nos tecidos periféricos. Apesar de dados farmacológicos anteriores evidenciaram que a abertura de canais de potassio dependente de voltagem esta envolvida na ação antinociceptiva do BDS 391, estudos eletrofisiológicos em ovócitos de Xenopus laevis indicraam que este composto não é capaz de atuar diretamente nesses canais. Os resultados obtidos neste estudo contribuem para o melhor entendimento da ação analgésica do BDS 391 e também para a caracterização da importância dos receptores serotoninérgicos $5 \mathrm{HT} 3$ periféricos para o controle da dor.

Palavras-chave: BDS 391. Anêmona do mar Bunodosoma cangicum. Antinocicepção. Receptores Serotoninérgicos. 


\begin{abstract}
Ferreira Junior WA. Characterization of the molecular mechanisms involved in the analgesic effect of Bunodosina 391, new compound obtained from Bunodosoma cangicum sea anemone venom. [Master thesis (Pharmacology)]. São Paulo: Instituto de Ciências Biomédicas da Universidade de São Paulo; 2010.
\end{abstract}

Animal toxins are directed against a wide variety of pharmacological targets, making them an invaluable source of ligands for studying, for example, the signaling pathways of pain and its control. Sea anemone (cnidaria) venoms contain many biologically active compounds such as cytolysins (18-20 kDa) and ion channel modulators (3-5 kDa). In addition, low molecular weight compounds have been isolated and identified in these venoms; however few studies have been carried out in order to determine the biological activity of such compounds. BDS 391 is a low molecular weight ( 390 Da) and non-peptidic compound purified from the Brazilian sea anemone Bunodosoma cangicum venom. Studies on the structure of BDS 391 have demonstrated that this compound is composed of a bromoindole group connected to histidine. Our recent data have indicated that BDS 391 administered by intraplantar (i.pl.) route into the rat hind paw induces potent peripheral analgesia in the rat paw pressure test. Initial results indicated that peripheral 5-HT receptors and $\mathrm{K}_{\mathrm{V}}$ channels mediate the analgesic action of this compound. The aim of the present work was to further characterize the analgesic action of BDS 391 and its mechanisms, determining its analgesic effect on different models of acute and chronic pain, the type of 5-HT receptor involved in this effect, the presence of these receptors in the inflamed tissue and the ability of BDS 391 to directly activate $\mathrm{K}_{\mathrm{V}}$ channels. BDS $391(0.15-150 \mu \mathrm{M})$ inhibited the nociceptive response induced by formalin in mice, and the hyperalgesia induced, in rats, by prostaglandin $\mathrm{E}_{2}$ or by the chronic constriction of sciatic nerve. Pharmacological studies indicated that peripheral $5-\mathrm{HT}_{3}$, but not $5-\mathrm{HT}_{1 \mathrm{a}}$ and $5-\mathrm{HT}_{2}$ receptors, mediate the action of BDS 391. Results obtained in immunoblotting assays confirmed that $5-\mathrm{HT}_{1 \mathrm{a}}, 5-\mathrm{HT}_{2}$ and $5-\mathrm{HT}_{3}$ receptors are expressed in nerve paw and dorsal root ganglia. Results of binding assays showed that BDS 391 does not displace the radiolabelled antagonist to $5-\mathrm{HT}_{1 \mathrm{a}}, 5-\mathrm{HT}_{2}$ and $5-\mathrm{HT}_{3}$, indicating that this compound does not directly bind to serotonergic receptors. In voltage clamp studies, BDS 391 was screened in 9 cloned voltage gated potassium channels. BDS 391 did not modify the peak or shape of ionic potassium current, indicating that opening of voltage gated potassium channels induced by BDS 391 does not result from a direct action of the compound on these channels, but could result from the (indirect) activation of $5-\mathrm{HT}_{3}$ receptors, a channel activated by ligand. These results contribute to the better comprehension of the analgesic action of BDS 391 and also points out the role of peripheral 5-HT 3 receptors for pain control.

Keywords: BDS 391. Bunodosoma cangicum sea amenone. Antinocicepion. Serotonin Receptors. 


\section{LISTA DE ABREVIATURAS E SIGLAS}

5-HT

5-BrIAA-His

6-BrIAA-His

6-BrIAA-OH

AMPc

ASIC

ATP

BCA

BDS 391

CCI

CEEA

CEUAIB

$\mathrm{CH}_{3} \mathrm{CN}$

CGRP

DMF

DRG

ERKs
Serotonina

5-Bromo-indolacético-histdina

6-Bromo-indolacético-histidina

6-Bromo-hidrox-indolacético

3', 5'- adenosina - monofosfato cíclico

Canais iônico para potássio sensível a pH

Adenosina trifosfato

Ácido bicinconínico

Bunodosina 391

Constrição crônica do nervo isquiático

Comissão de Ética em Experimentação animal do ICB-USP

Comissão de Ética o uso de animais do Instituto Butantan

Acetonitrila

Peptideo Relacionado ao Gene da Calcitonina

Dimetilformamida

Ganglio da raiz dorsal

Quinases reguladas por sinais extracelulares 
GABA

GMPc

$\mathbf{H}_{1},{ }_{2} \mathbf{e}_{3}$

hERG

HOBt

i. pl.

JNK

Kd

Ki

Kv

MAPKs

$\mathrm{MeOH}$

Nav

NMDA

$\mathrm{PGE}_{2}$

PKA

PKC

PKG

RNAm
Acido gama aminobutirico

Guanosina monofosfato cíclico

Receptores para histamina

Canais iônicos cardiaco humano para potássio

N-hidroxibenzotriazol

Administracao intraplantar

Quinase N-terminal c-Jun

Constante de dissociação

Constante de ionização

Canais para potássio dependentes de voltagem

Roteinoquinases ativadas por mitogenos

Metanol

Canais para sódio dependentes de voltagem

Receptor glutamatergico (N-metil-D-aspartato)

Prostaglandina $\mathrm{E}_{2}$

Proteinoquinase A

Proteinoquinase C

Proteinoquinase G

Acido ribonucléico mensageiro 
S. c.

SNC

TBTU

TFA

TRPV1
Administracao subcutânea

Sistema Nervoso Central

Tetrafluorato de O-(Benzotriazol-1-il)-N,N,N',N'-

tetrametilurônio

Acido trifloracetico

Canais catiônicos ativado por ligantes (transient receptor potential cation channel, subfamily $\mathrm{V}$, member 1 ) 


\section{LISTA DE ILUSTRAÇÕES}

Figura 1: Ordenha da peçonha da anêmona Bunodosoma cangicu ............................ 37

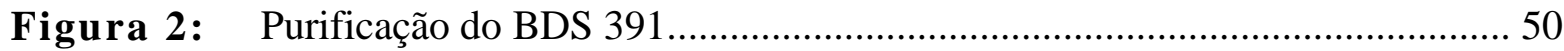

Figura 3: $\quad$ Espectro ESI-MS de BDS 391 ........................................................ 52

Figura 4: Varredura de absorbância do BDS 391 em Espectro de UV ........................ 53

Figura 5: $\quad$ Espectro de fragmentação MS/MS ......................................................... 54

Figura 6: Análise estrutural dos fragmentos da molécula BDS 391, "íons-filhos" detectados por espectrometria de massa ................................................. 55

Figura 7: Análise estrutural de BDS 391 por Ressonância Nuclear Magnética ........... 56

Figura 8: $\quad$ Efeito do BDS 391 sobre a hiperalgesia induzida por prostaglandina $\mathrm{E}_{2} \ldots 58$

Figura 9: Efeito do BDS 391 sobre a hiperalgesia e alodinia induzidas pela ligadura do nervo isquiático de ratos

Figura 10: Ação do BDS 391 sobre a nocicepção manifesta induzida por formalina .... 61

Figura 11: Efeito local do BDS 391 na hiperalgesia induzida por $\mathrm{PGE}_{2}$.................... 62

Figura 12: Ação local do BDS 391 sobre a nocicepção manifesta induzida por formalina

Figura 13: Envolvimento dos receptores para histamina no efeito antinociceptivo do BDS 391, no modelo de hiperalgesia induzida por $\mathrm{PGE}_{2}$ 64

Figura 14: Envolvimento dos receptores para serotonina no efeito analgésico do BDS 391, no modelo de hiperalgesia induzida por $\mathrm{PGE}_{2}$ 65

Figura 15: Envolvimento do receptor 5- $\mathrm{HT}_{3}$ no efeito antinociceptivo induzido pelo BDS 391 em modelo de dor persistente, induzido pela CCI 69 
Figura 16: Participação do receptor 5- $\mathrm{HT}_{3}$ no efeito antinociceptivo do BDS 391 sobre a nocicepção manifesta induzida por formalina 70

Figura 17: Ação do agonista $5-\mathrm{HT}_{3}$ sobre a nocicepção manifesta induzida por formalina 72

Figura 18: Expressão protéica de receptores serotoninérgicos 5- $\mathrm{HT}_{1 \mathrm{a}}, 5-\mathrm{HT}_{2}$ e 5-HT 3 .. 74

Figura 19: Avaliação da afinidade do BDS 391 por receptores 5-HT 77

Figura 20: Registros eletrofisiológicos em ovócitos de Xenopus laevis 79

Figura 21: Participação de canais Kv no efeito antinociceptivo do BDS391 em modelo de hiperalgesia induzida por $\mathrm{PGE}_{2}$ 80

Figura 22: Estrutura molecular do BDS 391 sintético e seus análogos 81

Figura 23: Efeito do BDS 391 sintético e seus análogos sobre a hiperalgesia induzida pólr prostaglandina $\mathrm{E}_{2}\left(\mathrm{PGE}_{2}\right)$ 82 


\section{SUMÁRIO}

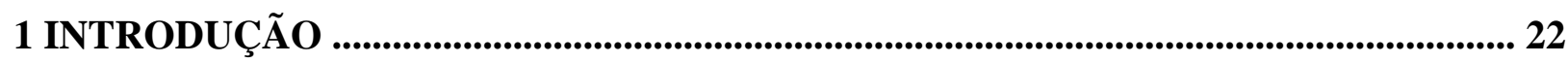

1.1 Toxinas de anêmonas do mar ................................................................................................................. 22

1.2 Dor-Consideraç̃̃es Gerais .................................................................................................................. 27

1.3 Aminas biogênicas no processo de geração e modulação da dor ............................................. 30

1.3.1 Serotonina (5-HT) ...................................................................................................................... 30

1.3.2 Histamina ........................................................................................................................................... 31

1.4 Controle periférico da dor .......................................................................................................................... 32

2 OBJETIVOS ….................................................................................................................................. 35

3 MATERIAL E MÉTODOS .............................................................................................................. 36

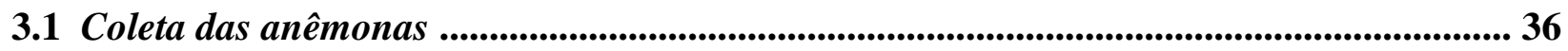

3.2 Extração e purificação da peçonha ................................................................................................... 36

3.2.1 Extração .......................................................................................................................................... 36

3.2.2 Purificação por gel-filtração em gel de Sephadex G-50 eestimativa do conteúdo

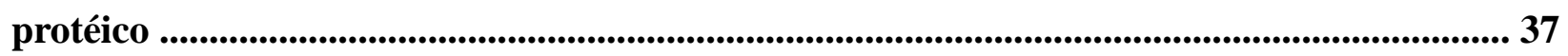

3.2.3 Purificação por cromatografia de fase reversa (RP-HPLC) da fração V ...................... 38

3.3 Determinação dos espectros de massa ................................................................................................. 38

3.4 Obtenção do BDS 391 sintético e análogos ................................................................................... 39

3.5 Determinação de letalidade ou atividade paralisante do BDS 391 ......................................... 40

3.6 Animais .............................................................................................................................................................. 41

3.7 Indução de hiperalgesia por prostaglandina $E_{2}$ em rato ............................................................... 41

3.8 Indução de dor neuropática em ratos ............................................................................................... 42

3.9 Modelo de pressão da pata de ratos para determinação da hiperalgesia ................................ 42 
3.10 Determinação da alodinia

3.11 Nocicepção induzida por formalina em camundongos

3.12 Tratamentos Farmacológicos

3.13 Determinação da expressão protéica de receptores 5-HT

3.14 Envolvimento de canais para Potássio dependentes de voltagem (Kv) no efeito antinociceptivo induzido pelo BDS 391

3.15 Ensaios de ligaçãa (binding) em receptores serotoninérgicos

3.16 Análise estatísitca

4 RESULTADOS

4.1 Fracionamento e Purificação da peçonha obtida da anêmona Bunodosoma cangicum

4.2 Determinação da estrutura molecular do composto BDS 391 52

4.3 Caracterização estrutural do BDS 391 por meio de analises de RMN e HR-MS 55

4.4 Determinação de letalidade ou de atividade paralisante do composto BDS 391 56

4.5 Efeito do composto BDS 391 sobre a hiperalgesia induzida por prostaglandina $\mathrm{E}_{2}\left(\mathrm{PGE}_{2}\right)$ 57

4.6 Efeito do BDS 391 sobre a hiperalgesia e alodinia causada pela ligadura do nervo isquiático de ratos (CCI) 59

4.7 Efeito do BDS 391 sobre a nocicepção induzida pela formalina 60

4.8 Avaliação da ação periférica (local) do BDS 391 61 4.9. Avaliação do envolvimento dos receptores parahistamina e serotonina no efeito do BDS 391 em modelo de hiperalgesia induzida por $P G E_{2}$ 63

4.9.1 Receptores $\mathrm{H}_{1}, \mathrm{H}_{2}$ e $\mathrm{H}_{3}$ para histamina 63

4.9.2 Receptores $5-\mathrm{HT}_{1 a}, 5-\mathrm{HT}_{2}$ e $5-\mathrm{HT}_{3}$ para serotonina 65

4.10 Envolvimento dos recepores $5-\mathrm{HT}_{3}$ no efeito antinociceptivo do BDS 391 em modelo de 
dor persistente $(\mathrm{CCI})$

4.11 Envolvimento dos receptores 5-HT 3 no efeito antinociceptivo do BDS 391 em modelo de dor manifesta induzida pela formalina

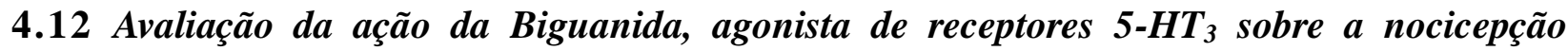
induzida por formalina 71

4.13 Expressão de receptores 5-HT no nervo da pata e no gânglio da raiz dorsal (DRG) 73

4.14 Ensaio de ligação ("binding”) do BDS 391 a receptores serotoninérgicos 77

4.15 Envolvimento de canais para Potássio dependentes de voltagem (Kv) no efeito antinociceptivo induzido pelo BDS 391 77

4.16 Efeito antinociceptivo do BDS 391 sintético e de seus análogos 80

5 DISCUSSÃO 83

6 CONCLUSÃO 92 REFERENCIAS 93 


\section{INTRODUÇÃO}

\subsection{Toxinas de anêmonas do mar}

Os Cnidários são considerados um grupo animal basal e altamente diversificado. $\mathrm{O}$ filo Cnidário é formado por anêmonas do mar, corais, águas vivas e hidras. Uma característica comum a todos esses animais é a presença de cnidocistos ou nematocistos. Estas estruturas celulares microscópicas, similares a arpões, são elaboradas no Aparelho de Golgi e posteriormente armazenadas em células especializadas denominadas Cnidócitos (Turk e Kem, 2009). Dentro das células, os cnidocistos ficam protegidos por um envoltório de colágeno. Os Cnidócitos possuem uma estrutura superficial sensorial, o Cnidocil, responsável pela percepção e resposta a diferentes estímulos. Após a ativação, os cnidocistos são ejetados para o meio extracelular, liberando rica gama de substâncias bioativas. Os animais desse grupo empregam suas toxinas tanto para capturar presas quanto para a defesa contra predadores. Embora existam cerca de 30 tipos morfologicamente distintos de cnidocistos, a maioria dos animais apresenta baixa diversidade destas estruturas (Turk e Kem, 2009).

A grande maioria das espécies descritas de Cnidários é considerada inofensiva quando em contato com a pele humana. Apenas uma pequena fração $(<1 \%)$ tem sido implicada em acidentes com humanos. No entanto, muitas toxinas vêm sendo isoladas da peçonha destes animais e caracterizadas tanto bioquímica quanto farmacologicamente. Desde a década de 1970, vários estudos vêm sendo realizados com o intuito de caracterizar os mecanismos envolvidos na ação das toxinas de anêmonas. Estes estudos elucidaram, por exemplo, os mecanismos de ação das toxinas ATX-I, II e III da anêmona Anemonia sulcata, habitante do mar Mediterrâneo, mostrando que estas toxinas retardam a inativação dos canais de sódio dependentes de voltagem (Beress et al., 1975; Norton et al., 1980). Adicionalmente a estas neurotoxinas, foi também mostrada a presença de hemolisinas na peçonha destes animais (Malpezzi e Freitas, 1991; Lagos et al., 2001; Anderluh e Macek, 2002; Oliveira et al., 2004). As hemolisinas são proteínas que formam poros em membranas celulares e causam desequilíbrio osmótico e lise celular (Lanio et al., 2001; Hong et al., 2002). 
Com o surgimento, nas décadas de 1970 e 1980, da técnica de "patch-clamp", a caracterização de peptídeos das mais diversas fontes animais, bem como de sua atividade biológica, teve avanço considerável. Neste sentido, foi possível evidenciar que as toxinas isoladas de anêmonas do mar apresentam ações em diversos tipos de canais iônicos, mostrando grande potencial farmacológico. Assim, foi observado que a toxina ShK, isolada da anêmona caribenha Stichodactyla helianthus, apresenta potente atividade bloqueadora de canais para $\mathrm{K}^{+}$dependentes de voltagem, discriminando principalmente os subtipos Kv1.1 e 1.3 (Kalman et al., 1998) e Kv3.2 (Yan et al., 2005). Os canais Kv1.3 são expressos em linfócitos-T, durante ativação do sistema imune. Desta forma, a caracterização de fármacos capazes de bloquear estes canais tornase altamente atrativa para terapias de controle de doenças auto-imunes (Ghanshani et al., 2000; Beeton et al., 2001; Beeton e Chandy, 2005). Neste sentido, foram obtidos, por meio de mutações sítio-dirigidas, análogos da toxina ShK com maior capacidade de bloquear estes canais, podendo favorecer o desenvolvimento de imunossupressores (Beeton et al., 2001).

Recentemente, foi descrita uma nova classe de toxinas peptídicas de anêmonas, cujos representantes principais são as toxinas APETx1 e APETx2 isoladas de extratos da anêmona Anthopleura elegantissima (Diochot et al., 2003, 2004). A APTx1 é um peptídeo modulador de canais para potássio do tipo hERG ("Human Ether-a-gogo Related Gene") e a APTx2, um bloqueador de canais do tipo ASIC (“Acid-sensing Ion Channels"). Da espécie japonesa Antheopsis maculata, Honma e Shiomi (Honma e Shiomi, 2005) isolaram outro peptídeo com seqüência primária similar a APETx1 e 2. Das anêmonas encontradas no Brasil, foi isolada e caracterizada, na peçonha da espécie Bunodosoma caissarum, espécie endêmica da costa brasileira, a toxina BcIV, que apresenta estrutura primaria semelhante a APETx1 e 2. Estudos eletrofisiológicos evidenciaram que a BcIV atua especificamente em correntes de $\mathrm{Na}^{+}$de crustáceos (Oliveira et al., 2006). Sugere-se que no futuro próximo, outras toxinas dessa nova categoria sejam isoladas e, consequentemente, novos canais iônicos, alvos destas toxinas, poderão ser caracterizados.

Em 1993, foi também isolada da fração neurotóxica da peçonha de B. caissarum, um polipeptídeo de 48 resíduos de aminoácidos, denominado BcIII, que pertence às toxinas do tipo 1 de anêmonas do mar (Malpezzi et al., 1993). As toxinas do tipo 1 apresentam posição conservada dos seis resíduos de cisteína, importantes para a determinação estrutural, discriminando canais de $\mathrm{Na}^{+}$(Norton, 1991). Estas toxinas se ligam ao sítio 3 destes canais de $\mathrm{Na}^{+}$. A BcIII foi ensaiada 
em canais de sódio dos tipos Nav 1.1 a 1.6, os quais estão presentes no sistema nervoso central (Nav1.1, 1.2, 1.3), sistema nervoso periférico (Nav1.6), musculatura esquelética (Nav1.4) e cardíaca (Nav1.5). Os resultados mostraram que a BcIII e outras duas toxinas das anêmonas Anemonia sulcata (ATXII) e Anthopleura fuscoviridis (AFTII) ligam-se a alguma outra região dos canais de sódio, além do sítio 3 (Oliveira et al., 2004). Como consequência deste tipo de ligação, há retardo na inativação desses canais e aumento do pico da corrente e da corrente persistente. Esses dados sugerem que outras regiões dos canais de sódio, alem do sitio 3, estão envolvidas no processo de inativação dos mesmos, abrindo a possibilidade de que os peptídeos de anêmonas sejam empregados como protótipos para o desenvolvimento de novas drogas ou como importantes ferramentas farmacológicas no estudo da biofísica de canais de sódio.

Outra anêmona da costa brasileira que vem sendo estudada é a Bunodosoma cangicum, congênere de B. caissarum. Araque e colaboradores (Araque et al., 1995) detectaram atividade inibitória da peçonha destes animais, sobre canais de $\mathrm{K}^{+}$dependentes de $\mathrm{Ca}^{2+}$. Posteriormente, Lagos e colaboradores (Lagos et al., 2001) observaram que diferentes frações da peçonha deste animal apresentavam atividade hemolítica e neurotóxica. Estas neurotoxinas atuam sobre canais de sódio dependentes de voltagem, além de inibirem canais de potássio dependentes de voltagem (Wanke et al., 2009; Moran et al., 2009; Zaharenko et al., 2008; Yeung et al., 2005). Foi também isolado e caracterizado, da B. cangicum, um novo peptídeo, denominado Cangitoxina (CGTX), contendo 48 resíduos de aminoácidos, claramente pertencente às toxinas do tipo 1 das anemonas, (Cunha et al., 2005). Posteriormente, Zaharenko e colaboradores (Zaharenko et al., 2008) demonstraram a presença de duas isoformas desta toxina, CGTXII e CGTXIII, que são eluídas juntamente com a Cangitoxina.

Além de neurotoxinas com atividade em canais de sódio e potássio, foi também demonstrada a presença, na peçonha de anêmonas do mar, de toxinas peptídicas com atividade analgésica. Andreev e colaboradores observaram que o APHC1, um polipeptideo de 56 resíduos de aminoácidos obtido da anêmona Heteractis crispa, induz efeito analgésico (Andreev et al., 2008). Este efeito parece estar correlacionado a ação desta toxina em receptores TRPV1, uma vez que estudos in vitro mostraram que o composto bloqueia parcialmente as correntes iônicas induzidas, nestes canais, por capsaicina. 
Além das neurotoxinas e das hemolisinas, a peçonha das anêmonas contem compostos de baixo peso molecular. Apesar dos avanços no conhecimento sobre a ação das toxinas peptídicas, pouco ainda se conhece sobre a atividade biológica destes compostos de baixo peso molecular.

Garateix e colaboradores (Garateix et al., 1996) observaram que uma fração de baixo peso molecular, eluída no final da cromatografia de gel-filtração (Sephadex G-50) da peçonha da anêmona Phyllactis flosculifera, bloqueava receptores glutamatérgicos metabotrópicos em neurônios de gastrópodes. Sabe-se, por exemplo, que o neurotransmissor muscular de crustáceos e insetos é o glutamato. Desta forma, é possível que predadores desses invertebrados tenham desenvolvido, além de toxinas que atuem em canais iônicos, toxinas que possam interferir com receptores glutamatérgicos.

Recentemente foram isolados compostos bromados e de baixo peso molecular da peçonha da anêmona do mar B. cangicum. Por meio de filtração em gel, obteve-se uma fração que é eluída no final do cromatograma, denominada de fração $\mathrm{V}$ (FrV). Após repurificação desta fração em cromatografia líquida de fase reversa de alto desempenho (HPLC), foram obtidos vários compostos de massas moleculares variando entre 300 e 600 Da. A estrutura dessas moléculas é composta de um núcleo estrutural semelhante à serotonina e conectada, por meio de uma ligação peptídica, a um aminoácido. No composto majoritário da fração V, denominado Bunodosina 391 (BDS 391), a ligação peptídica ocorre entre o núcleo molecular serotonina-símile e uma histidina (Zaharenko et al., 2010 - prelo). Apesar da estrutura molecular semelhante à serotonina, foi demonstrado, pela primeira vez, em nosso laboratório, por meio de ensaios farmacológicos, que o composto BDS 391, administrado por via intraplantar em ratos, aumenta o limiar nociceptivo destes animais, no teste de pressão de patas (modelo de nocicepção mecânica). Estudos farmacológicos mostraram que este efeito é mediado pela ativação de receptores para serotonina e histamina, mas não por receptores opióides. Foi demonstrado também, o envolvimento de canais de potássio dependentes de voltagem nesse efeito antinociceptivo (Ferreira Júnior WA e Cury Y, 2010 - em fase de elaboração) ${ }^{1}$. Em relação aos receptores 5-HT, foi evidenciado, neste mesmo teste, que antagonistas seletivos para o receptor do subtipo 5-HT 3 , mas não 5-HT 1 a 5 $\mathrm{HT}_{2}$, revertiam este efeito, indicando o envolvimento destes receptores na ação do BDS 391. É importante ressaltar que o subtipo 5-HT 3 é um receptor de canal iônico não específico, diferente dos demais subtipos de receptores 5-HT, que são acoplados à proteína G (Faerber et al., 2007). Apesar desses dados e do fato da molécula BDS 391 ter uma estrutura similar a serotonina, não é 
possível ainda afirmar que este composto é capaz de atuar diretamente sobre os receptores $5-\mathrm{HT}_{3}$. Ainda, apesar de acarretar aumento no limiar nociceptivo dos animais, não foi, até o momento, avaliada a capacidade do BDS 391 em interferir com a nocicepção manifesta ou em modelos de hipernocicepção aguda e crônica.

Os resultados mostrando o envolvimento de receptores $5-\mathrm{HT}_{3}$ e de receptores histaminérgicos no aumento do limiar nociceptivo induzido pelo BDS 391, são intrigantes, uma vez que vários dados de literatura têm evidenciado que a administração periférica de histamina ou serotonina (5-HT), ao contrário do observado no SNC, acarreta efeitos nociceptivos (Giordano e Gerstmann, 2004; Taiwo e Levine, 1992; Giordano e Rogers, 1989). Contudo, efeitos controversos destas aminas, na modulação da dor, têm sido relatados (Kesim et al., 2005; Zeitz et al., 2002; Sommer, 2006).

Dados de literatura têm sugerido que a 5-HT, por meio da ação em diferentes subtipos de receptores, particularmente receptores $5 \mathrm{HT}_{1}, 5 \mathrm{HT}_{2}$ e $5 \mathrm{HT}_{3}$, pode induzir dor ou analgesia. Estes dados tem mostrado que no SNC, a serotonina é um importante inibidor da transmissão da informação nociceptiva (Bardin et al., 1997, 2000), contudo, na periferia, várias evidencias experimentais têm indicado que a administração ou liberação de serotonina pode evocar dor ou analgesia (Zeitz et al., 2002; Mueller e Quock, 1992; Doak e Sawynok, 1997; Tokunaga et al., 1998; Sommer, 2004). Da mesma forma, a histamina tem sido apontada como importante modulador da transmissão da dor, sendo, porém, esta ação dependente do sítio de sua administração ou liberação, da dose administrada e do receptor envolvido (receptores $\mathrm{H}_{1}, \mathrm{H}_{2}$ ou $\mathrm{H}_{3}$ ) (Malmberg e Yaksh, 1994; Brown et al., 2001; Farzin et al., 2002; Raffa, 2001). Contudo, está bem estabelecido que perifericamente, esta amina apresenta efeito hipernociceptivo (Raffa, 2001; Malmberg e Basbaum, 1998).

Baseados nos dados obtidos pelo nosso grupo, mostrando que receptores histaminérgicos e serotoninérgicos estão envolvidos na alteração do limiar nociceptivo periférico induzido pelo BDS 391 e em dados da literatura que mostram o envolvimento destes receptores tanto na dor quanto na analgesia, torna-se relevante a ampliação dos estudos sobre os mecanismos envolvidos na ação do BDS 391, com o intuito de melhor entender a participação de receptores serotoninérgicos e histaminérgicos neste efeito e para a caracterização do tipo de interação da molécula com estes receptores, bem como avaliar a sua capacidade em acarretar analgesia em 
modelos de nocicepção manifesta, aguda ou persistente.

\subsection{Dor-Considerações Gerais}

A transmissão da dor está associada à atividade elétrica das fibras nervosas aferentes primárias, as quais possuem terminações sensoriais nos tecidos periféricos, denominadas nociceptores (receptores da dor). Os nociceptores são terminações nervosas livres sendo uma continuação da própria fibra nervosa sensitiva. Os nociceptores ou fibras aferentes nociceptivas primárias são normalmente ativados por estímulos de alta intensidade. Estes estímulos podem ser de origem mecânica, térmica e/ou química.

Os neurônios aferentes primários desempenham três funções principais no que diz respeito à nocicepção: 1- detecção do estímulo nociceptivo ou nocivo (transdução); 2- condução do impulso da periferia para a medula espinhal; 3- transferência desses impulsos para neurônios secundários e interneurônios presentes em lâminas específicas do corno dorsal da medula espinhal (transmissão sináptica) (Caviedes e Herranz, 2002; Basbaum et al., 2009; Vanderah, 2007). Da medula espinhal, as informações nociceptivas são conduzidas ao tronco cerebral, tálamo e córtex cerebral, onde ocorre a percepção da dor (Basbaum et al., 2009; Vanderah, 2007; Schaible e Richter, 2004; Wootton, 2004).

Muitas fibras aferentes nociceptivas são desprovidas de mielina e, portanto possuem baixa velocidade de condução. Estas fibras são denominadas fibras C e são também caracterizadas como nociceptores polimodais, uma vez que respondem a estímulos mecânicos, térmicos e químicos. As fibras nociceptivas mielinizadas, denominadas $\mathrm{A} \delta$, conduzem mais rapidamente os estímulos periféricos. As fibras nociceptivas terminam nas camadas superficiais do corno dorsal da medula espinhal, formando conexões sinápticas com os neurônios secundários que se dirigem ao tálamo (Basbaum et al., 2009; Belmonte e Cervero, 1996; Julius e Basbaum, 2001; Rangb et al., 1997). Durante o desenvolvimento de uma resposta inflamatória, fibras nociceptivas, particularmente as do tipo C, são sensibilizadas e, consequentemente, podem ser ativadas por estímulos de menor intensidade, acarretando hipernocicepção (aumento da resposta a estímulos nocivos) ou alodinia (resposta a estímulos não nocivos) (Kidd e Urban, 2001; Dworkin et al., 
2003), considerados os mais importantes fenômenos nociceptivos de um processo inflamatório. Cabe ressaltar que os termos hipernocicepção e alodinia são usualmente empregados para descrever sensação de dor em humanos. Assim, alguns trabalhos têm empregado o termo "hipernocicepção" para descrever o fenômeno de hiperalgesia em animais (Farzin et al., 2002; Loeser e Treede, 2008; Malmberg-Aiello et al., 1998; Parada et al., 2003). É importante salientar que, além dos receptores polimodais $\mathrm{C}$, um grupo adicional de nociceptores, denominados receptores "silenciosos" ou "adormecidos" (silent/sleeping nociceptors), são ativados durante processos inflamatórios, contribuindo para a hipernocicepção. Estas fibras aferentes são encontradas na pele, articulações e em órgãos viscerais (Schaeffer et al., 1988; Schemelz et al., 1994).

Várias substâncias sintetizadas e/ou liberadas durante o processo inflamatório, tais como prótons extracelulares, mediadores lipídicos, incluindo prostaglandinas, além de citocinas, bradicinina, histamina, serotonina, entre outros, podem interferir com a atividade dos neurônios nociceptivos primários (Basbaum et al., 2009; Schaible e Richter, 2004; Julius e Basbaum, 2001). Os mediadores periféricos da hipernocicepção atuam via receptores ligados a intermediários celulares regulatórios (proteína G, segundos mensageiros), que regulam a permeabilidade da membrana e a concentração iônica celular (Pan et al., 2008; Bevan, 1999; Reichling e Levine, 1999). A sensibilização dos neurônios nociceptivos primários é decorrente, em parte, do incremento das concentrações intracelulares de AMPc, ativação de proteínoquinases, como PKA, acarretando a fosforilação de canais iônicos e o aumento do influxo de $\mathrm{Ca}^{2+}$ intracelular. A conseqüência destes efeitos metabólicos é a despolarização parcial da membrana neuronal facilitando a geração e a transmissão de impulsos nervosos (Cunha et al., 1999; Ferreira, 1994; England et al., 1996). Alguns mediadores hipernociceptivos elevam diretamente as concentrações intracelulares de AMPc, enquanto outros, cujos receptores não estão acoplados a adenilato ciclase, sensibilizam nociceptores por mecanismos independentes da formação direta do AMPc. Estes mecanismos incluem a geração de prostanóides e a ativação da proteínoquinase C (PKC) (Bevan, 1999). A ativação da PKC acarreta a fosforilação e o aumento da atividade de canais iônicos permeáveis a $\mathrm{Ca}^{2+}$ e $\mathrm{Na}^{+}$(Basbaum et al., 2009; Julius e Basbaum, 2001; Millan, 1999; Lorenzetti e Ferreira, 1996). Tem sido proposto ainda que a via das proteínoquinases ativadas por mitógeno (MAPquinases/MAPKs), que se inicia pela fosforilação de resíduos de tirosina e treonina, pode ser ativada independentemente da presença da PKC ou PKA (Dina et al., 2003). 
Esta via de sinalização é composta por 3 membros: quinases reguladas por sinais extracelulares (ERKs), quinase N-terminal c-Jun (JNK) e a p-38 MAPK (Ji e Woolf, 2001; Ramam et al., 2007). Dados da literatura têm mostrado a participação das MAPKs, mais especificamente das ERKs, em processos hipernociceptivos (Ramam et al., 2007; Daí et al., 2002; Obata e Noguchi, 2004; Daulhac et al., 2006). Independentemente do mecanismo de sinalização intracelular, o aumento na expressão e fosforilação de canais iônicos em membranas de neurônios periféricos é o principal fator responsável pelo aumento da excitabilidade da membrana destas células (Woolf, 2000). Os principais canais iônicos responsáveis pela geração de potenciais de ação na membrana de neurônios nociceptivos são os canais de sódio e de cálcio dependentes de voltagem (Woolf, 2004; Vanegas e Schaible, 2000; Saegusa et al., 2002). Além dos canais de sódio e cálcio, canais de potássio dependentes de voltagem têm papel relevante no controle da dor. A perda da função dos canais de potássio envolvidos na determinação do limiar de potencial de ação ou na repolarização da membrana celular, pode alterar a excitabilidade dos neurônios ocasionando aumento da sensibilidade a estímulos nocivos e/ou diminuindo a suscetibilidade a analgésicos. Desta maneira, os canais para potássio dependente de voltagem $(\mathrm{Kv})$ se tornaram um potencial alvo terapêutico para o tratamento de diversas doenças, incluindo síndromes dolorosas (Wulff et al., 2009). Além disso, várias evidencias experimentais tem sugerido o envolvimento de canais de potássio sensíveis a ATP na ação analgésica de diversos fármacos, incluindo os opióides (Khanna et al., 2010; Lohmann e Welch, 1999).

Além da sensibilização dos neurônios nociceptivos primários, outros mecanismos podem estar envolvidos na gênese da hipernocicepção e alodinia, como excitabilidade ectópica, aumento da excitabilidade dos neurônios no corno dorsal da medula espinhal ou no núcleo trigeminal do tronco cerebral (Sensibilização Central), reorganização estrutural e redução da atividade de sistemas inibitórios endógenos (Woolf, 2004; Costigan e Woolf, 2000).

O corno dorsal da medula espinhal é um sítio importante no processo de transmissão e modulação da informação nociceptiva da periferia para o SNC (Aimone e Yaksh, 1989; Yaksh, 1999). O principal neurotransmissor excitatório envolvido na sensação nociceptiva é o glutamato, enquanto neuropeptídeos como a substância P, a neurocinina A e o Peptídeo Relacionado ao Gene da Calcitonina (CGRP) parecem atuar como neuromoduladores da transmissão nociceptiva (Schaible e Richter, 2004; Kidd e Urban, 2001). Estes neuromoduladores agem em receptores específicos na membrana pós-sináptica, favorecendo a transmissão da informação nociceptiva. A 
ativação e a modulação dos receptores NMDA para glutamato têm papel importante na indução e manutenção da sensibilização dos neurônios medulares (Sensibilização Central) (Schaible e Richter, 2004). Contudo, a liberação de neuropeptídeos, de fatores neurotróficos e de prostaglandinas, neste sítio medular, também contribui para a gênese do processo de Sensibilização Central (Schaible e Richter, 2004; Woolf, 2000; Besson, 1999). Dados de literatura têm evidenciado ainda, que as células da glia (astrócitos e microglia) presentes na medula espinhal, por meio da liberação ou captação de vários mediadores nociceptivos, contribuem também para a Sensibilização Central (Wieseler-Frank et al., 2004; Ren e Dubner, 2008; Smith, 2010).

A transmissão nociceptiva na medula espinhal é modulada por tratos descendentes excitatórios e inibitórios, os quais podem atuar em fibras aferentes primárias, ou ter ações em fibras pós-sinápticas ou em interneurônios presentes no corno dorsal da medula espinhal (Cousins, 2005). Os múltiplos tratos descendentes inibitórios se originam de núcleos presentes no tronco cerebral. Neurotransmissores como acetilcolina, GABA, glicina e opióides modulam a atividade destes tratos descendentes inibitórios (Millan, 2002). A nocicepção é, portanto, um processo gerado na periferia e modulado no SNC. Alterações no controle descendente da nocicepção também podem provocar sensibilização central e, consequentemente, estados hipernociceptivos.

\subsection{Aminas biogênicas no processo de geração e modulação da dor}

\subsubsection{Serotonina $(5-H T)$}

A serotonina (5-HT) está envolvida nos processos de dor e seu controle, tanto no sistema nervoso periférico quanto no sistema nervoso central (SNC) (Eide e Hole, 1993).

Vários dados experimentais têm mostrado que a liberação de 5-HT, no SNC, induz efeito analgésico (Yaksh e Tyce, 1979; Yaksh e Wilson, 1979). O aumento na concentração de 5-HT no corno dorsal da medula espinhal, ativa os interneurônios inibitórios presentes neste sitio medular, resultando na inibição da transmissão da informação nociceptiva (Peng et al., 1996). Diversos 
subtipos de receptores serotoninérgicos, como 5- $\mathrm{HT}_{1}, 5-\mathrm{HT}_{2}$ e 5- $\mathrm{HT}_{3}$, medeiam o efeito analgésico da serotonina no SNC (Liu et al., 1988; Lin et al., 1996).

Nos tecidos periféricos, diferentemente da ação no SNC, a serotonina é considerada um mediador inflamatório pró-nociceptivo (Nicholson, 2003). A principal fonte celular de 5-HT nos tecidos periféricos, são as plaquetas e os mastócitos. A concentração desta amina aumenta rapidamente quando ocorre inflamação ou outra lesão tecidual periférica (Sommer, 2006). A ação biológica da serotonina, liberada após injúria tecidual, depende dos subtipos de receptores presentes nos neurônios aferentes primários, que são ativados por ela. O RNAm para os subtipos de receptores 5- $\mathrm{HT}_{1 \mathrm{~B}}, 5-\mathrm{HT}_{1 \mathrm{D}}, 5-\mathrm{HT}_{2 \mathrm{~A}-\mathrm{C}}, 5-\mathrm{HT}_{3}, 5-\mathrm{HT}_{4}$ e 5- $\mathrm{HT}_{7}$ tem sido detectado em gânglios da raiz dorsal, sugerindo a presença destes receptores nos neurônios sensitivos primários, incluindo as fibras C (Nicholson, 2003; Pierce et al., 1996; Fozard, 1984). Estes estudos têm sugerido que a 5-HT pode atuar diretamente sobre as fibras C, porém o papel funcional da ativação dos diferentes tipos de receptores 5-HT por esta amina, ainda não está totalmente elucidado.

Perifericamente, a serotonina é tanto um ativador direto da transdução como um sensibilizador para outros agentes transdutórios. A serotonina, liberada durante injuria periférica, pode ligar-se a receptores $5-\mathrm{HT}_{3}$, localizados nas terminações nervosas, favorecendo a abertura de canais iônicos e a passagem de correntes de $\mathrm{Na}^{+}, \mathrm{K}^{+}$e $\mathrm{Ca}^{++}$, resultando na despolarização de fibras nervosas e geração de potenciais de ação. É importante salientar que o receptor 5-HT 3 é um receptor de canal catiônico pertencente à família de receptores GABA, em contraste com os demais subtipos de receptores 5-HT, os quais são receptores acoplados à proteína G (Faerber et al., 2007). A serotonina também se liga aos receptores 5- $\mathrm{HT}_{2 \mathrm{~A}}$, presentes em fibras nervosas aferentes primarias, iniciando o processo de sensibilização, via proteína $\mathrm{G}$ e processos dependentes da ação da fosfolipase C (Ness, 2001).

\subsubsection{Histamina}

A histamina tem papel importante na percepção da dor e modulação dos processos nociceptivos (Suzuki et al., 1994; Cannon e Hough, 2005). No SNC, os neurônios histaminérgicos se originam a partir de núcleos tuberomamilares, localizados no hipotálamo 
posterior. Estes núcleos recebem informações vindas principalmente do sistema límbico. Os neurônios histaminérgicos, originados a partir do hipotálamo e presentes na substância cinzenta periaquedutal, são considerados como importantes moduladores da dor (Hough et al., 1988). O aumento na concentração de histamina no SNC acarreta efeito antinociceptivo em diversos modelos de avaliação da sensibilidade dolorosa (Malmberg et al., 1994; Netti et al., 1994). O efeito da histamina no SNC é mediado pela ativação de receptores histaminérgicos do tipo $\mathrm{H}_{1}, \mathrm{H}_{2}$ e $\mathrm{H}_{3}$ (Cannon e Hough, 2005; Passani et al., 2000). Os subtipos de receptores $\mathrm{H}_{1}$ e $\mathrm{H}_{2}$ para histamina estão envolvidos no efeito da histamina nas vias nociceptivas (Hough et al., 1999; Galeotti et al., 2004). Tem sido evidenciada, também, a interação entre a histamina e drogas opióides, no SNC, contudo estes dados são ainda controversos. Estudos experimentais têm mostrado que o efeito antinociceptivo induzido pela morfina é aumentado em camundongos "knockout" para receptores $\mathrm{H}_{1}$ (Mobarakeh et al., 2002), sugerindo que receptores histaminérgicos interferem com o efeito analgésico de drogas opióides. Por outro lado, dados de literatura têm evidenciado que a administração de morfina induz a liberação de histamina na substância cinzenta periaquedutal (Barke e Hough, 1994). Adicionalmente, foi observado que a administração subcutânea de zolantidine, um antagonista de receptor $\mathrm{H}_{2}$, inibe parcialmente o efeito antinociceptivo da morfina nos modelos de "tail-flick" e "hot-plate" em ratos, indicando que estes receptores são importantes para a ação do opióide (Gogas et al., 1989).

Apesar da caracterização do papel modulador da histamina no processo de transmissão de dor no SNC, os estudos mostrando o envolvimento de receptores histaminérgicos na nocicepção, na periferia são, ainda, escassos. Embora a presença de receptores $\mathrm{H}_{3}$ para histamina em neurônios centrais já tenha sido evidenciada (Sander et al., 2008; Arrang et al., 1983; Panula et al., 1984), apenas em 2007, Cannon et al. (2007) demonstraram, por meio de estudos imunoquímicos, que o receptor $\mathrm{H}_{3}$ também esta presente em fibras sensitivas e em neurônios do gânglio da raiz dorsal. A ativação de receptores $\mathrm{H}_{3}$ reduz a liberação de mediadores inflamatórios peptidérgicos (Ohkubo e Shibata, 1995; Ohkubo et al., 1995), além de interferir com a inflamação e dor de origem inflamatória (Cannon e Hough, 2005; Poveda et al., 2006). A demonstração de que receptores $\mathrm{H}_{3}$ são importantes moduladores da nocicepção, torna estes receptores alvos terapêuticos importantes para o controle da dor. 


\subsection{Controle periférico da dor}

O desenvolvimento de novos fármacos analgésicos tem objetivado a busca por fármacos desprovidos de efeitos adversos no SNC e/ou que tenham preferencialmente ação periférica, ou ainda, que possuam alta especificidade por alvos moleculares envolvidos na dor, diminuindo assim, os efeitos adversos dessas drogas. Estes estudos, além de favorecer a obtenção de novos fármacos analgésicos, têm contribuído para ampliar o conhecimento dos mecanismos periféricos envolvidos na dor, bem como na sua modulação, ainda na fibra nervosa aferente primária. É importante salientar que os estudos visando o desenvolvimento de novos fármacos analgésicos têm mostrado que toxinas isoladas de venenos animais, em decorrência de sua seletividade e especificidade por canais iônicos, enzimas e componentes de membranas neuronais (receptores metabotrópicos e ionotrópicos) envolvidos no processo de transmissão da dor e de seu controle, apresentam potencial como agentes terapêuticos para o tratamento da dor (Cury e Picolo, 2006; Cury e Picolo, 2009a, 2009b).

Analgésicos, de maneira geral, atuam prevenindo a sensibilização dos nociceptores (Ferreira, 1972; Ferreira et al., 1973), como os antiinflamatórios não esteroidais, ou interferindo, direta ou indiretamente, com os receptores da dor já sensibilizados, como, por exemplo, a dipirona, os opióides ou substâncias liberadoras de opióides endógenos e o óxido nítrico (Ferreira, 1994; Ferreira et al., 1988; Ferreira e Lorenzetti, 1995).

Vários estudos sobre os mecanismos moleculares envolvidos na ação periférica dos fármacos que agem interferindo com os receptores da dor já sensibilizados, têm mostrado a existência de uma via única comum para a ação de alguns destes fármacos. Estes trabalhos têm evidenciado que opióides, substancias doadoras de óxido nítrico ou mesmo antiinflamatórios não esteroidais, como o ketorolac promovem analgesia via ativação da via óxido nítrico/GMPc/PKG e abertura de canais para potássio (Lorenzetti e Ferreira, 1996; Ferreira e Lorenzetti, 1995; Duarte et al., 1992; Ferreira et al., 1991; Rodrigues e Duarte, 2000; Lázaro-Ibáñez et al., 2001; Alves et al., 2004; Sachs et al., 2004). Desta forma, os canais de potássio têm sido considerados como um dos mediadores finais da ação analgésica periférica destes fármacos. Estes canais têm sido caracterizados como canais de potássio sensíveis a ATP, ativados por cálcio ou dependentes de voltagem. (Santos et al., 1999; Galeotti et al., 1999; Ortiz et al., 2002). 
Como mencionado anteriormente, foi evidenciado que o BDS 391, composto majoritário da fração $\mathrm{V}$ isolada da peçonha da anêmona do mar B. cangicum acarreta alteração no limiar nociceptivo basal dos ratos, efeito este mediado pela ativação de receptores 5-HT. Dados preliminares indicam ainda a possível participação de receptores histaminérgicos nesse efeito antinociceptivo. Contudo não está bem caracterizado o tipo de receptor serotoninérgico e histaminérgico envolvido neste efeito. Ainda, como apontado pelos dados da literatura, o envolvimento de receptores serotoninérgicos e histaminérgicos em processos nociceptivos, favorecendo ou inibindo o seu desenvolvimento, é ainda bastante controverso. Assim, a ampliação dos estudos sobre a caracterização do efeito antinociceptivo periférico induzido pelo BDS 391, por meio de análises mais específicas da interação do BDS 391 com os subtipos de receptores serotoninérgicos e histaminérgicos, poderão contribuir para o melhor conhecimento sobre os mecanismos moleculares envolvidos no efeito deste composto, bem como do papel periférico da histamina e serotonina nas vias de transmissão de dor e de seu controle. 


\section{OBJETIVO}

Baseado em nossos dados anteriores, mostrando que o composto BDS 391, obtido a partir da peçonha da anêmona do mar Bunodosoma cangicum, acarreta aumento do limiar nociceptivo de ratos e que este efeito é mediado pela ativação de receptores periféricos serotoninérgicos e, possivelmente, histaminérgicos, e também pela abertura de canais de potássio, o objetivo geral deste projeto foi ampliar a caracterização analgésica deste composto e dos mecanismos envolvidos nesta ação, avaliando:

$\checkmark \quad$ o efeito antinociceptivo do BDS 391 e análogos sintéticos, em modelo de nocicepção manifesta induzida por formalina, em modelo de hipernocicepção induzida por Prostaglandina $\mathrm{E}_{2}\left(\mathrm{PGE}_{2}\right)$, e em modelo de dor persistente (dor neuropática) induzida por constrição crônica do nervo ciático;

$\checkmark \quad$ o envolvimento dos receptores periféricos $\mathrm{H}_{1}, \mathrm{H}_{2}$ e $\mathrm{H}_{3}$ para histamina e de receptores periféricos $5-\mathrm{HT}_{1}, 5-\mathrm{HT}_{2}$ e $5-\mathrm{HT}_{3}$ para serotonina no efeito antinociceptivo induzido pelo BDS 391;

$\checkmark \quad$ a possível ligação do BDS 391 em receptores $5-\mathrm{HT}_{1 \mathrm{a}}, 5-\mathrm{HT}_{2}$ e $5-\mathrm{HT}_{3}$;

$\checkmark \quad$ a expressão protéica dos receptores para serotonina $\left(5-\mathrm{HT}_{1 \mathrm{a}}, 5-\mathrm{HT}_{2}\right.$ e $\left.5-\mathrm{HT}_{3}\right)$ no nervo da pata e no gânglio dorsal da medula espinhal dos animais;

$\checkmark \quad$ se o BDS 391 é capaz de ativar diretamente canais para potássio dependentes de voltagem (Kvs). 


\section{MATERIAL E MÉTODOS}

\subsection{Coleta das anêmonas}

As anêmonas do mar da espécie Bunodosoma cangicum foram coletadas nas praias arenosas e rochosas do canal de São Sebastião, no mesolitoral inferior e na franja do infralitoral, durante a maré-baixa, quando são facilmente encontradas. Os animais ficaram mantidos por $24 \mathrm{~h}$ em aquários, para a eliminação de eventuais partículas alimentares presentes na cavidade gastrovascular. A coleta e manutenção dos animais, bem como a extração e purificação da peçonha da anêmona B. cangicum foram realizadas no Laboratório de Farmacologia de Produtos Naturais Marinhos, sob a supervisão do Prof. Dr. José Carlos de Freitas.

\subsection{Extração e purificação da peçonha}

\subsubsection{Extração}

A extração da peçonha foi realizada por estimulação elétrica, de acordo com a metodologia descrita por Malpezzi et al. (1993). Os exemplares foram mergulhados em um mesmo béquer (para concentrar o material) com cerca $20 \mathrm{~mL}$ de água do mar artificial e individualmente estimulados eletricamente, por meio de um estimulador Grass Instruments, modelo SD-9, com intensidade de saída do aparelho de $100 \mathrm{~V}$ (a voltagem medida na água do mar com o animal imerso chega a ser de apenas de 1 a 3 V, devido a corrente de curto-circuito). A duração de cada estímulo foi de $10 \mathrm{~ms}$, sendo aplicados durante 60s a cada animal. Para a estimulação foram utilizados 2 eletrodos de carbono, um colocado dentro da cavidade gastrovascular do animal e outro na água circundante, encostado na coluna e nos tentáculos, fechando o circuito (Figura 1). Essa seqüência foi repetida por 6 a 7 vezes com cada indivíduo do grupo de 10 anêmonas. O líquido obtido foi centrifugado a 10000 g, por $7 \mathrm{~min}$, para a remoção de possíveis partículas contaminantes do sobrenadante. O material foi liofilizado e conservado a -20 ${ }^{\mathrm{o}} \mathrm{C}$. 
Esse procedimento permite a obtenção de uma mistura polipeptídica tóxica, praticamente sem contaminação com proteínas estruturais corpóreas (Malpezzi et al., 1993). Além disso, outro aspecto que deve ser considerado é que os animais se recuperam muito bem após algumas horas da estimulação, o que permite reutilizá-los e, após, devolvê-los ao ambiente marinho.

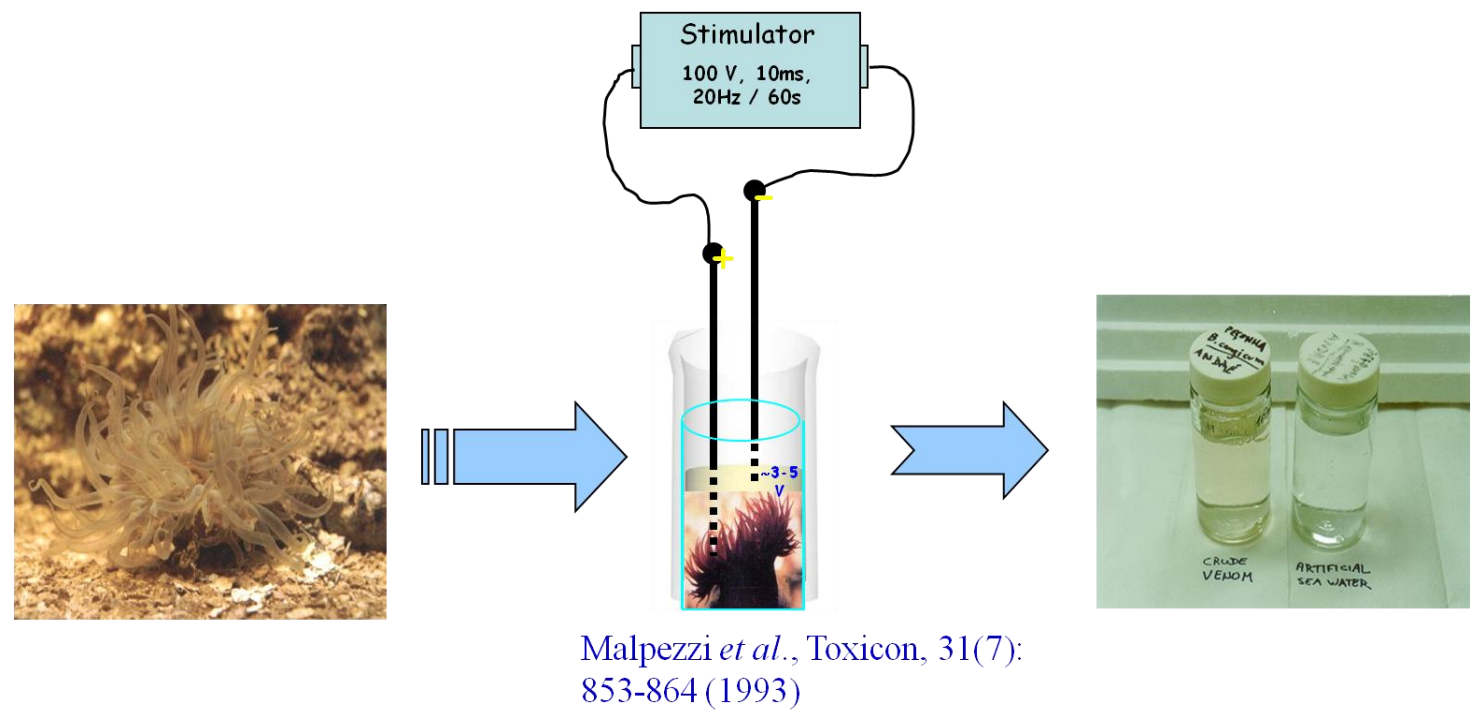

Figura 1: Extração da peçonha da anêmona Bunodosoma cangicum por meio de estimulação elétrica.

\subsubsection{Purificação por gel-filtração em gel de Sephadex G-50 e estimativa do conteúdo protéico}

O fracionamento da peçonha liofilizada de $B$. cangicum foi realizado através de uma coluna $(1,9 \mathrm{~cm}$ X $131 \mathrm{~cm}$ ) empacotada com gel Sephadex G-50 (Pharmacia LKB- Biotechnology, Uppsala, Suécia) (Lagos et al., 2001). A peçonha, previamente centrifugada e liofilizada (cerca de 1-2 g de material seco; $70 \mathrm{mg}$ de proteína), foi dissolvida em 10-20 $\mathrm{mL}$ de tampão acetato de amônio 0,1M, pH 7,0 e aplicada ao topo da coluna, equilibrada e eluída por gravidade com o mesmo tampão.

A absorbância de cada fração, uma medida relativa da quantidade de proteína, foi registrada diretamente na saída da coluna, através da passagem do efluente por um detector de UV (Spectra/ Chrom ${ }^{\mathrm{TM}}$ Flow Thru UV Monitor com unidade óptica de $280 \mathrm{~nm}$ e UV Monitor 
Controller, Spectrum, Austria), antes de entrar no coletor de frações. A informação, captada pelo detector, é integrada e registrada permanentemente em papel (Spectra/ Chrom TM 1 Channel

Recorder, Spectrum, Áustria). O registro direto na saída da coluna, permite o acompanhamento constante do processo de filtração em gel, desta maneira, otimizando o processo de coleta.

Para estimar a quantidade de proteína presente na peçonha e nas frações obtidas, durante esta etapa e nas subseqüentes, foi utilizado "kit" que se baseia no método de dosagem do ácido bicinconínico (BCA), seguindo-se o protocolo do manual do fabricante (Pierce, Rockford, EUA). Albumina sérica bovina foi utilizada como padrão.

\subsubsection{Purificação por cromatografia de fase reversa (RP-HPLC) da fração V}

O conjunto da fração $\mathrm{V}$, obtida na cromatografia por filtração em gel, foi ressuspendido em água Milli-Q (Millipore Inc.) e injetado em um sistema de purificação Shimadzu de HPLC constituído por um detector UV-VIS SPD-10A VP, bombas LC-10AD VP e um sistema controlador SCL-10A VP (Shimadzu Corp., Japão). A amostra foi cromatografada em uma coluna semipreparativa C-18 de fase reversa (10 x $250 \mathrm{~mm}, 5 \mu \mathrm{m}$; Capcell PAK Shiseido $\left.{ }^{\mathrm{TM}}\right)$, através de um gradiente linear de 5 a 55\% (em 45min) do solvente "B", composto de acetonitrila $+0,1 \%$ de ácido trifluoroacético $\left(\mathrm{CH}_{3} \mathrm{CN} /\right.$ 0,1\% TFA) com fluxo de 2,5 mL/min durante 50min, através de monitoramento em UV $214 \mathrm{~nm}$. O solvente "A" é composto de 0,1\% de TFA em água Milli-Q. Todos os picos foram coletados manualmente e individualmente, para a obtenção dos compostos de baixo peso molecular utilizados no presente estudo.

\subsection{Determinação dos espectros de massa}

Esta etapa foi realizada no Laboratório de Toxinologia Aplicada do Instituto Butantan (LETA / CAT - CEPID) sob a co-orientação do pesquisador Dr. Katsuhiro Konno.

Os espectros de massa foram adquiridos utilizando dois espectrômetros de massa: Ettan Maldi-Tof/Pro (Matrix Assisted Laser Desorption Ionization - Time of Flight) (Amersham 
Biosciences, Suécia) e espectrômetro do tipo "ElectroSpray Ionisation" (ESI) Q-Tof Ultima API (Micromass, Manchester, UK) em configuração Qq-orthogonal-Tof (time-of-flight).

No espectrômetro do tipo MALDI-TOF, o ácido $\alpha$-ciano-4-hidróxicinâmico (SIGMA, St. Louis, USA) foi empregado como matriz para peptídeos. As amostras e a matriz foram sempre dissolvidas em uma solução de 1:1 de $\mathrm{H}_{2} 0$ e acetonitrila e misturadas em igual volume, sendo sempre aplicadas em duplicata nas placas. Laser de nitrogênio a $337 \mathrm{~nm}$ foi empregado para ionizar e volatilizar as amostras, com intensidades de 70 a 100\% (unidades arbitrárias). Os espectros foram sempre adquiridos em modo reflectron positivo. Modo positivo significa que o equipamento detecta íons carregados com cargas positivas. $\mathrm{O}$ equipamento foi operado e os espectros processados através dos programas EttanMaldi Control e EttanMaldi Evaluation, respectivamente, fornecidos pelo fabricante. A calibração do equipamento foi executada antes da análise das amostras, através de verificação de espectros de proteínas e peptídeos padrões fornecida no Calibration Kit for MALDI-TOF MS (Sigma, St. Louis, EUA).

Para o equipamento ESI (“ElectroSpray Ionization") Q-Tof Ultima API, as amostras foram reconstituídas em uma solução de $50 \%$ de acetonitrila contendo $1 \%$ de ácido fórmico e aplicadas $(5 \mu \mathrm{L})$ em um loop Rheodyne de $10 \mu \mathrm{L}$ e direcionadas ao espectrômetro através de uma bomba Shimadzu LC-10AVP ajustada a um fluxo fixo de $20 \mu \mathrm{L} / \mathrm{min}$. A voltagem do spray variou de 1,0 a $2,0 \mathrm{kV}$ e a temperatura capilar selecionada em cerca de $100{ }^{\circ} \mathrm{C}$. Para a fragmentação dos íons selecionados (ESI-MS/MS), foram utilizadas intensidades arbitrárias de argônio que variavam de 15 a $35 \%$. Os espectros foram obtidos em modo positivo e analisados utilizando-se o software MassLynx 4.0, fornecido pelo fabricante. A calibração do equipamento foi executada também antes da análise das amostras, através da interpretação do espectro de NaI (Sigma, St. Louis, USA).

\subsection{Obtenção do BDS 391 sintético e análogos}

Esta etapa foi realizada em colaboração com o Dr. Katsuhiro Konno, atualmente professor do Instituto de Medicina Tropical da Universidade de Toyama, Toyama, Japão.

A síntese do composto BDS 391 (6-BrIAA-His) foi realizada manualmente, utilizando 
sintetizador de peptídeos automatizado MAPS-8 (Shimadzu Corporation, Kyoto, Japão), pelo método de fase sólida. Inicialmente a aminoacilresina His(Trt)-2-ClTrt foi suspendida em dimetilformamida (DMF), posteriormente foi adicionado uma nova solução em DMF contendo ácido 6-Bromo-indolacético, TBTU [tetrafluorato de O-(Benzotriazol-1-il)-N,N,N',N'tetrametilurônio] e $\mathrm{HOBt}$ ( $\mathrm{N}$ - hidroxibenzotriazol). A mistura permaneceu então em agitação, por 1 hora, em temperatura ambiente. A suspensão foi então filtrada. A resina obtida na fase anterior foi lavada com metanol $(\mathrm{MeOH})$ e o composto foi clivado da resina por reação com ácido acético/trifluoroetanol/diclorometano (1:1:8), por 1 hora em temperatura ambiente. A solução foi filtrada e liofilizada. O resíduo oleoso foi dissolvido em uma solução ácido trifluoracético (TFA)/ $\mathrm{H}_{2} \mathrm{O} 95 \%$ e mantida por $1 \mathrm{~h}$ em temperatura ambiente. Na última etapa, a solução final foi diluída em água e particionada em DCM/ $\mathrm{H}_{2} 0$ (1:1). A fase aquosa foi liofilizada e purificada por RP-HPLC, em coluna YMC-Pack ODS (20 x 150 mm, Yamamura Kagaku, Kyoto, Japão), utilizando eluição isocrática de $20 \%$ ACN $/ 0,1 \%$ TFA/ $\mathrm{H}_{2} \mathrm{O}$, com fluxo de 7 $\mathrm{mL} / \mathrm{min}$. O BDS 391 sintético foi caracterizado por espectrometria de massa, utilizando MALDITOF MS e por co-eluição com BDS 391 natural, em equipamento de HPLC acoplado ao espectrômetro de massa ESI-MSMS.

Análogos do BDS 391, sintetizados de forma similar ao método descrito acima, foram produzidos para avaliar o papel do átomo de Bromo, presente na estrutura molecular do BDS 391, na ação antinociceptiva induzida pelo composto. Foi possível também avaliar a importância da histidina neste efeito. Para tanto, foram desenvolvidos 3 análogos do BDS 391 sintético. O composto 5-BrIAA-His, apresenta uma alteração na posição do átomo do Bromo. Por outro lado, o átomo do Bromo esta ausente no análogo BrIAA-His. Foi desenvolvido também o análogo 6BrIAA-OH, no qual não há a ligação peptídica com a histidina.

\subsection{Determinação de letalidade ou atividade paralisante do BDS 391}

Uma vez que o BDS 391 foi obtido a partir da peçonha da anêmona e não se conhece ainda, seus possíveis efeitos tóxicos, foi avaliado, presentemente, a possível letalidade ou atividade paralisante deste composto. Para a execução deste experimento seguimos a metodologia de Honma et al. (2003, 2005), empregando siris azuis adultos, em fase de intermuda, da espécie 
Callinectes danae. Os animais pesavam em geral de 15 a 80 g e eram injetados com diferentes doses do composto BDS 391. As amostras eram diluídas em solução fisiológica de C. danae, sempre na concentração de $1 \mathrm{mg} / \mathrm{mL}$, padronizando-se um volume de $2 \mu \mathrm{L}$ de solução fisiológica para cada grama de peso bruto do animal. Os mesmos eram injetados na junção dos apêndices locomotores e do abdômen e observados por um período de até $2 \mathrm{~h}$ após a injeção. Apenas os animais que morriam ou que permaneciam paralisados até o final desse período eram considerados como tendo sofrido efeito da amostra e computados nos experimentos. Para fim de comparação, as toxinas BcIII e BcIV, obtidas da anêmona Bunodosoma caissarum, foram utilizadas como controle positivo. O efeito da BcIII e BcIV, sobre correntes de $\mathrm{Na}^{+}$, já foi descrito na literatura (Oliveira et al., 2004, 2006).

\subsection{Animais}

Foram utilizados ratos Wistar e camundongos Swiss, machos, pesando, respectivamente, entre 160 - 180 g e 18 - 22 g, fornecidos pelo Biotério Central do Instituto Butantan. Os animais foram mantidos com água e ração ad libitum em uma sala apropriada, com isolamento acústico, temperatura controlada $\left(22 \pm 1{ }^{\circ} \mathrm{C}\right)$ e ciclo claro/escuro $(12: 12 \mathrm{~h})$, por um período mínimo de 3 dias antes dos experimentos. Os protocolos experimentais foram aprovados pela Comissão de Ética em Experimentação animal - CEEA / Protocolo $n^{0} 115$ nas fls. 62 do livro 02 - Instituto de Ciências Biomédicas da Universidade de São Paulo e pela Comissão de Ética no uso de animais do Instituto Butantan - CEUAB / Protocolo 494/08.

\subsection{Indução de hiperalgesia por prostaglandina $E_{2}$ em ratos}

Para indução de hiperalgesia, foi preparada uma solução estoque de prostaglandina $\mathrm{E}_{2}$ ( $\mathrm{PGE}_{2}$ ), dissolvendo-se $500 \mu \mathrm{g}$ de $\mathrm{PGE}_{2}$ em $1 \mathrm{~mL}$ de etanol. No momento do uso, essa solução estoque foi novamente diluída em salina estéril. A dose de prostaglandina utilizada foi de $100 \mathrm{ng}$ em $100 \mu \mathrm{L}$ de salina, administrada por via intraplantar (i.pl.). A hiperalgesia foi avaliada 3h após a injeção da $\mathrm{PGE}_{2}$. Animais injetados com salina ou com salina mais a proporção de etanol 
utilizada para diluição da $\mathrm{PGE}_{2}$, por via i.pl., foram inicialmente utilizados como controles.

\subsection{Indução de dor neuropática em ratos}

Para a indução de dor neuropática, foi realizada a constrição crônica do nervo isquiático de ratos, de acordo com método descrito por Bennett e Xie (1988). Os animais foram anestesiados com halotano. O nervo isquiático foi exposto na região mediana da coxa, afastandose o músculo bíceps femoral. Próximo à trifurcação do nervo isquiático, a $7 \mathrm{~mm}$ de distância da trifurcação, foram realizadas 4 ligaduras (fio categute cromado 4-0) frouxas ao redor deste, distantes entre si em aproximadamente $1 \mathrm{~mm}$. As ligaduras foram realizadas ao longo do nervo, até 4-5 mm do ponto inicial. A incisão foi suturada em camadas, utilizando fio de sutura de seda número 4-0. Como parâmetros para avaliação da instalação da dor neuropática, foram determinados os fenômenos de hiperalgesia e alodinia, no $14^{\circ}$ dia do pós-operatório

\subsection{Modelo de pressão da pata de ratos para determinação da hiperalgesia}

Para avaliação da sensibilidade dolorosa foi utilizado o teste de pressão da pata de ratos (Analgesy-Meter Ugo Basile ${ }^{\circledR}$, Itália), realizado de acordo com o método descrito por Randall e Sellito (1957).

Neste teste, uma força em gramas (g), de magnitude crescente (16 g/s), é continuamente aplicada sobre o dorso das patas posteriores do rato e interrompida quando o animal apresenta a reação de "retirada" do membro. Neste modelo, o limiar de dor é representado como a força (g) necessária para a indução da reação.

Este teste foi aplicado antes (medida inicial) e 3h após a administração de $\mathrm{PGE}_{2}$ ou 14 dias após a indução da CCI.

Os resultados foram analisados através da comparação das médias das medidas iniciais e finais ou, quando determinado, através da comparação das médias obtidas nos diferentes grupos experimentais. 


\subsection{Determinação da alodinia}

Foi avaliada por ensaio quantitativo, em resposta a estímulo tátil aplicado às patas do rato, segundo método descrito por Chaplan et al. (1994) modificado. Neste teste, os ratos foram colocados, individualmente, em gaiolas plásticas, com fundo de arame, para permitir acesso às patas destes animais. Para o ensaio de alodinia, foi empregada uma série logarítmica de 10 filamentos de von Frey (Aesthesiometer Semmer-Weinstein, Stoelting Co., E.U.A). A calibração dos filamentos é definida como Log 10 (gramas x 10000), tendo os seguintes valores (o valor em gramas está entre parênteses): 3,61 (0,407 g); 3,84 (0,692 g); 4,08 (1,202 g); 4,17 (1,479 g); 4,31 $(2,041 \mathrm{~g}) ; 4,56$ (3,630 g); 4,74 (5,495 g); 4,93 (8,511 g); 5,07 (11,749 g) e 5,18 (15,136 g). Cabe ressaltar que os filamentos com peso superior a 15,136 g não foram empregados nos estudos de alodinia. Os filamentos foram aplicados, um a um, perpendicularmente, sob a área plantar de ambas as patas posteriores e mantidos por um período de 8 segundos. Os ensaios foram iniciados com o filamento de 2,041 g. O filamento capaz de elicitar a retirada da pata, duas vezes consecutivas, foi considerado como a força em gramas necessária para elicitar a resposta (100\% de resposta). Na ausência de resposta ao filamento inicial (2,041 g), a apresentação dos filamentos foi realizada de forma ascendente, até a observação de duas respostas consecutivas para um mesmo filamento. Na ausência de resposta ao maior estímulo (15,135 g), este filamento foi considerado como valor de corte. Esta forma de apresentação dos filamentos minimiza o risco de habituação do animal à resposta (Milligan et al., 2000).

O valor da força (em log) para induzir 50\% de resposta de retirada da pata foi calculado pela aplicação de uma função psicométrica integral de Gaussian. Esta função foi aplicada para as respostas obtidas para cada filamento de von Frey, utilizando um método de ajuste de probabilidade máxima. Os limiares de resposta estimados a partir da função integral de Gaussian tornam-se, desta forma, apropriados para análise estatística para métrica. A função Gaussiana foi aplicada utilizando programa de computador Psycofit.

Este teste foi aplicado antes e no $14^{\circ}$ dia após a ligadura do nervo isquiático.

Os resultados foram avaliados através da comparação das medidas iniciais e finais ou, quando determinado, através da comparação das médias obtidas nos diferentes grupos experimentais. 


\subsection{Nocicepção induzida por formalina em camundongos}

Como descrito por Dubuisson e Dennis (1977), a administração de formalina induz nocicepção inflamatória neurogênica caracterizada por duas fases distintas. $20 \mu \mathrm{L}$ de formalina (1\%) por via subcutânea no dorso da pata posterior direita. Os camundongos foram colocados imediatamente em caixas transparentes posicionadas em frente a um espelho, de maneira a facilitar a observação quantitativa do comportamento nociceptivo por meio da contagem do numero de "flinches" da pata tratada. Os resultados foram avaliados em duas fases distintas. $\mathrm{Na}$ primeira fase ou fase neurogênica, as medidas foram obtidas durante o período de 0 a 10 minutos. Na segunda fase ou fase inflamatória, as medidas foram obtidas no período de 20 a 40 minutos.

\subsection{Tratamentos Farmacológicos}

* BDS 391, diluído em salina, foi administrado por via intraplantar (i.pl.), na dose $150 \mathrm{nM}, 150$ minutos após a injeção da $\mathrm{PGE}_{2}$, nas doses de $150 \mathrm{nM}, 1,5$ e $150 \mu \mathrm{M}$, no $14^{\circ}$ dia após a ligadura do nervo isquiático, ou nas doses de $150 \mathrm{nM}$ e 1,5 $\mu \mathrm{M}, 30 \mathrm{~min}$ antes da injeção de formalina. As concentrações do BDS 391 foram baseadas em estudos anteriores realizados em nosso laboratório (Picolo et al., 2008).

Como mencionado na Introdução, dados anteriores indicam o envolvimento de receptores para serotonina e histamina no efeito antinociceptivo induzido pela molécula BDS 391. Para a caracterização dos subtipos destes receptores, foram utilizados os seguintes antagonistas:

Antagonistas de receptores para histamina:

* Tioperamida, antagonista de receptor $\mathrm{H}_{3}$, diluída em salina estéril, administrada na dose de $5 \mathrm{mg} / \mathrm{kg}$, por via s.c., 15min. antes do BDS 391 (Cannon e Hough, 2005);

* Pirilamina, antagonista de receptor $\mathrm{H}_{1}$, diluída em salina esteril, administrada na dose de $5 \mathrm{mg} / \mathrm{kg}$, por via s.c., 15min. antes do BDS 391 (Malmberg-Aiello et al., 1998); 
* SKF, antagonista de receptor $\mathrm{H}_{2}$, diluído em salina estéril, administrado na dose de $5 \mathrm{mg} / \mathrm{kg}$, por via s.c., 15min. antes do BDS 391.

Antagonistas de receptores para serotonina:

* Spiroxatrine, antagonista de receptor 5-HT $1 \mathrm{a}$, diluído em salina estéril, administrado na dose de $6 \mathrm{mM}(300 \mathrm{nmol} / 50 \mu \mathrm{L})$, por via i.pl., 15min antes do BDS 391;

Ketanserin, antagonista de receptor 5- $\mathrm{HT}_{2}$, diluído em salina estéril, administrado na dose de $6 \mathrm{mM}(300 \mathrm{nmol} / 50 \mu \mathrm{L})$, por via i.pl., 15min antes do BDS 391;

- Ondansetron, antagonista de receptor $5-\mathrm{HT}_{3}$, diluído em salina estériel, administrado na dose $6 \mathrm{mM}(300 \mathrm{nmol} / 50 \mu \mathrm{L})$, por via i.pl., 15min antes do BDS 391.

A dose efetiva dos antagonistas específicos para os subtipos $5-\mathrm{HT}_{1 \mathrm{a}}, 5-\mathrm{HT}_{2}$ e $5-\mathrm{HT}_{3}$ foi determinada em ensaios preliminares, por meio de experimentos dose-resposta frente a agonistas específicos destes receptores (dados não mostrados).

Com o intuito de confirmar que a ativação de receptores 5- $\mathrm{HT}_{3}$ induz efeito antinociceptivo, foi avaliado o efeito de um agonista destes receptores no modelo de nocicepção manifesta:

Biguanida, agonista de receptor 5- $\mathrm{HT}_{3}$, administrado nas doses 3, 6 e $10 \mu \mathrm{M}$, por via i.pl., 30 minutos antes da injeção da formalina $1 \%$.

Todos os antagonistas e agonistas foram adquiridos da empresa Sigma (Sigma/Aldrich EUA).

Grupos controles foram constituídos por animais tratados com os veículos utilizados para a diluição das drogas, nas mesmas condições experimentais.

\subsection{Determinação da expressão protéica de receptores 5-HT}

A presença de RNA mensageiro (RNAm), para receptores serotoninérgicos, nos gânglios da raiz dorsal foi demonstrada por alguns autores (Chen et al., 1998, Pierce et al., 1996, Nicholson et al., 2003), no entanto, a presença destes receptores nas terminações nervosas periféricas ainda não foi confirmada. Assim em decorrência da demonstração de que receptores 
serotoninérgicos periféricos estão envolvidos no efeito do BDS 391, investigamos presentemente, a expressão periférica dos receptores para 5-HT, por meio de ensaio de "immunoblotting". Avaliamos também, se a administração plantar de $\mathrm{PGE}_{2}$ promove alteração na expressão protéica de receptores $5-\mathrm{HT}_{1}, 5-\mathrm{HT}_{2}$ e $5-\mathrm{HT}_{3}$.

A expressão dos receptores foi realizada em amostras do nervo plantar e DRG (L4-L6) em animais naive e sensibilizados por $\mathrm{PGE}_{2}$. Para sensibilização, os animais foram tratados com $\mathrm{PGE}_{2}$ e três horas após, foram eutanasiados por $\mathrm{CO}_{2}$. Para a remoção dos DRGs, foi realizada uma incisão no dorso do animal, a camada muscular foi retirada e a medula espinhal exposta após a retirada das vértebras. Os gânglios foram coletados e imediatamente congelados em gelo seco. Para a retirada do nervo, foi removida a camada de tecido conjuntivo da pata e o nervo foi excisado até a altura da articulação do joelho. Animais controles foram constituídos por animais naive (não submetidos ao tratamento com $\mathrm{PGE}_{2}$ ). As amostras foram homogeneizadas por maceração manual em tampão RIPA à $4{ }^{\circ} \mathrm{C}$ (1\% Igepal CA-630, 0,5\% deoxicolato de sódio, 0,1\% mM PMSF, $10 \mathrm{mg} / \mathrm{ml}$ aprotinina, $1 \mathrm{mM}$ ortovanato de sódio em tampão PBS, $\mathrm{pH} 7.4)$ e centrifugadas a $10.000 \mathrm{~g}$ por $20 \mathrm{~min}$, a $4{ }^{\circ} \mathrm{C}$. Após a centrifugação, a concentração de proteína foi determinada pelo método de Bradford (Bradford, 1976). Alíquotas contendo $80 \mu \mathrm{g}$ de proteína total foram fervidas em tampão Laemmli por 4 minutos e posteriormente, submetidas à eletroforese em gel de poliacrilamida (SDS-PAGE 12\%) em aparelho para minigel (MiniProtean, EUA). Após a separação por eletroforese, as proteínas foram transferidas para uma membrana de nitrocelulose (BioRad- EUA). A membrana foi bloqueada "overnight" em TBST (20 mM Tris-HCL, $150 \mathrm{mM} \mathrm{NaCl}$, e 0,1\% Tween 20) contendo 5\% de leite desnatado, seguida pela incubação com anticorpos anti-receptor $5-\mathrm{HT}_{1}$, anti-receptor $5-\mathrm{HT}_{2}$ e anti-receptor $5-\mathrm{HT}_{3}$ (1:1000 Abcam - EUA) IgG policlonal (de coelho), "overnight" à $4{ }^{\circ} \mathrm{C}$. Posteriormente, a membrana foi lavada três vezes com TBS-T e então incubada por 2 horas com anti-IgG de coelho conjugado à peroxidase (1:5000, Sigma- Aldrich, EUA). A membrana foi visualizada utilizando solução ECL (Amershan-Biosciences, Reino Unido) por 60s e então exposta ao filme de raio X (IBF, Brasil) em sala escura. Os filmes foram escaneados e o peso molecular e a densidade óptica das bandas foram determinadas pelo programa Totallab (Nonlinear Dynamics Ltd, EUA). A quantidade de proteína de cada amostra foi normalizada pela incubação da membrana com anticorpo para GAPDH (1:10.000) (Santa Cruz Biotechnology, EUA). 


\subsection{Envolvimento de canais para Potássio dependentes de voltagem (Kv) no efeito antinociceptivo induzido pelo BDS 391}

Os estudos eletrofisiológicos com BDS 391 foram realizados no Laboratório de Toxicologia do Departamento de Ciências Farmacêuticas da Universidade de Leuven - Bélgica, sob a orientação do Prof. Dr. Jan Tytgat. Para os registros de "voltage clamp" foram utilizados ovócitos, nos estágios V e VI, de Xenopus laevis. Estes ovócitos foram obtidos por ovariectomia, na qual fêmeas de $X$. laevis foram anestesiadas com 3-etil éster do ácido aminobenzóico metanossulfonato 0,5 g (Sigma-Aldrich / EUA). As fêmeas foram mantidas em gelo, durante todo o procedimento. Os ovócitos foram, imediatamente após a remoção, colocados em solução ND96 livre de $\mathrm{Ca}^{2+}$ (em mM: $\mathrm{NaCl}$ 96, $\mathrm{KCl} 2, \mathrm{MgCl}_{2}$ 1, HEPES 5, $\mathrm{pH}$ = 7,5). A desfoliculação foi induzida pelo tratamento com $2 \mathrm{mg} / \mathrm{ml}$ de colagenase (Sigma-Aldrich / EUA). Os ovócitos desfoliculados foram injetados com cRNAs entre 1 e $24 \mathrm{~h}$.

Os experimentos eletrofisiológicos foram realizados em temperatura ambiente $\left(18-24{ }^{\circ} \mathrm{C}\right)$. Para a aquisição dos registros foram empregados 2 eletrodos com resistência abaixo de $3 \mathrm{M} \Omega$, quando preenchidos com solução $\mathrm{KCl}$ 3M. Para iniciar os registros, os ovócitos foram transferidos para uma preparação contendo solução de banho (em mM): $\mathrm{NaCl}$ 96, $\mathrm{KCl}$ 2, $\mathrm{CaCl}_{2}$ $1,8, \mathrm{MgCl}_{2}$ 1, e HEPES 5 (pH 7,4). Os registros de "voltage clamp" na configuração "whole cell" foram obtidos utilizando um amplificador Clamp 500, filtrado a $1 \mathrm{KHz}$, utilizando o software pCLAMP (Molecular Devices, Sunnyvale, CA, EUA).

\subsection{Ensaios de ligação (binding) em receptores serotoninérgicos}

Estes experimentos foram realizados pela empresa Ricerca Biosciences, LLC - Taipei, Taiwan.

A afinidade do BDS 391 por receptores serotoninérgicos foi determinada por ensaio de "binding", utilizando o método descrito por Schreiter e colaboradores (Schreiter et al., 2003) com algumas adaptações. Resumidamente, a afinidade do composto BDS 391 pelos receptores para serotonina foi determinada por ensaios de competição. Como marcador, foram empregados os radioligantes $\left[{ }^{3} \mathrm{H}\right]$ 8-OH-DPAT (1,5 nM), $\left[{ }^{3} \mathrm{H}\right]$ Kentanserin $(0,5 \mathrm{nM})$ e $\left[{ }^{3} \mathrm{H}\right]$ GR65630 $(0,69 \mathrm{nM})$, 
respectivamente, antagonistas específicos de receptores $5-\mathrm{HT}_{1 \mathrm{a}}, 5-\mathrm{HT}_{2}$ e $5-\mathrm{HT}_{3}$, adicionados à solução tampão $50 \mathrm{mM}$ Tris-HCL, pH 7,4. Para estes ensaios, foram utilizadas células recombinantes transfectadas (HEK-293 e CHU-K1). O experimento consistiu na incubação das células recombinantes com o $\operatorname{BDS} 391(2 \mu \mathrm{M})$ não marcado, juntamente com os ligantes radioativos específicos, durante 60 minutos à temperatura ambiente $\left(25^{\circ} \mathrm{C}\right)$. Todos os experimentos foram realizados em duplicata.

Os parâmetros de ligação dos receptores 5-HT foram determinados ajustando os dados experimentais seguindo a equação:

$$
[\mathrm{B}]=\left[\mathrm{B}_{0}\right] /\left\{\mathbf{1}+\left(\mathrm{IC}_{50} /[\text { competitor }]\right)^{-\mathrm{n}}\right\}
$$

sendo $[\mathrm{B}]$ e $[\mathrm{Bo}]$ as concentrações dos radioligantes na presença e na ausência do BDS 391, respectivamente. O IC $_{50}$ foi determinado como a concentração do BDS 391 capaz de deslocar 50\% do radioligante. A constante de inibição $\left(\mathrm{K}_{\mathrm{i}}\right)$ do BDS 391 foi estimada pela equação de Cheng-Prusoff (Hovius et al., 1998), na qual [L] e Kd são a concentração e a constante de dissociação do radioligante, respectivamente.

$$
\mathbf{K i}=\mathbf{I C 5 0} /\{1+([L] / K d)\}
$$

\subsection{Análise estatísitca}

A análise estatística foi realizada por meio de análise de variância (Snedecor et al., 1946) associado ao teste de Tukey (Sokal e Rohlf, 1981), para comparação de mais de duas médias. O índice de significância foi de $\mathrm{p}<0,05$. 


\section{RESULTADOS}

\subsection{Fracionamento e Purificação da peçonha obtida da anêmona Bunodosoma cangicum}

Cerca de $200 \mathrm{mg}$ da peçonha foram aplicados ao topo da coluna de gel filtração (sephadex G-50), que foi eluída por gravidade com tampão acetato de amônio 0,1M (pH 7,0), gerando cinco frações (Figura 2A). A fração final (FrV) obtida na primeira etapa de purificação, liofilizada e diluída a em água Milli-Q, foi em seguida purificada por HPLC. A Figura 2B representa uma cromatografia de fase reversa de uma injeção analítica dessa fração. Todos os picos obtidos foram coletados manualmente e individualmente para serem posteriormente submetidos à espectrometria de massa. As escalas das ordenadas mostram as unidades arbitrárias de absorbância a 214 nm (esquerda) e o percentual de solvente B (direita) empregado na purificação.

Os parâmetros empregados na aquisição dos espectros foram descritos de acordo com o item 3.3 da seção Materiais e Métodos. Os resultados obtidos nessa abordagem proteômica estão compilados na tabela 1 . 


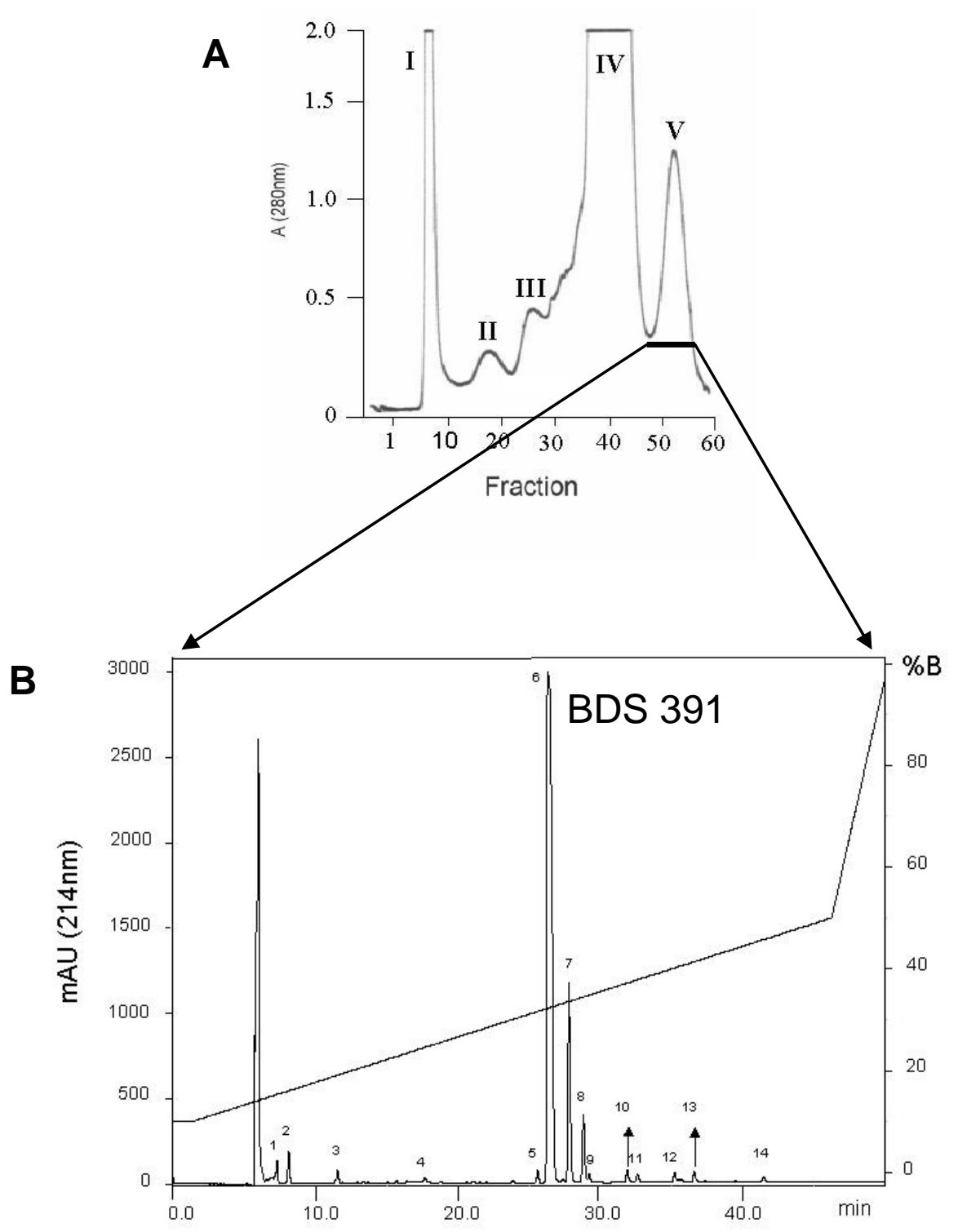

Figura 2: (A) Perfil cromatográfico de cerca de $200 \mathrm{mg}$ de proteína presente na peçonha de B.cangicum aplicados à coluna de gel de Sephadex G-50 (1,3 cm X $131 \mathrm{~cm}$ ). Foram obtidas 5 frações (I,II, III, IV e V) Com base na literatura, as frações II e III possivelmente correspondem as frações hemolíticas e neurotóxicas, respectivamente. A barra horizontal representa o "pool" de fração que foi liofilizado e submetido a cromatografia de HPLC de fase reversa. (B) Cromatograma representativo de uma recromatografia da fração V (Fr V). Os números acima dos picos são denominações arbitrárias de cada um deles, de acordo com a ordem de eluição no cromatograma. A linha continua (\% B) representa a variação do gradiente empregada. Empregou-se um gradiente linear de 5 a $55 \%$ de solvente $\mathrm{B}\left(\mathrm{CH}_{3} \mathrm{CN} / 0,1 \% \mathrm{TFA}\right)$ a um fluxo de $2,5 \mathrm{~mL} / \mathrm{min}$ durante $45 \mathrm{~min}$. O composto majoritário da $\mathrm{FrV}$, denominado como pico 6 , é a molécula alvo do nosso estudo (BDS 391). 
Tabela 1 - Perfil de massa molecular dos picos e frações obtidas da purificação em HPLC de fase reversa da fração final $(\mathrm{FrV})$ da peçonha de Bunodosoma cangicum. Observar a diferença de 2 unidades de massa entre vários sinais detectados nesses experimentos.

\begin{tabular}{|c|c|c|}
\hline NÚMERO DO PICO & TEMPO DE RETENÇÃO (MIN) & MASSA MOLECULAR $[\mathrm{M}+\mathrm{H}]^{+}$ \\
\hline 1 & 7.25 & Não determinada \\
\hline 2 & 8.07 & Não determinada \\
\hline 3 & 11.51 & Não determinada \\
\hline 4 & 17.66 & Não determinada \\
\hline 5 & 25.65 & $945.3 ; 947.3$ \\
\hline$\underline{6\left(1^{\circ} \text { pico majoritário }\right)}$ & 26.39 & $391 ; 393$ \\
\hline $7\left(2^{\circ}\right.$ pico majoritário $)$ & 27.80 & $781.1 ; 783.1$ \\
\hline$\underline{8\left(3^{\circ} \text { pico majoritário }\right)}$ & 28.80 & 405; 407; 809.1; 811.1 \\
\hline 9 & 29.22 & 410.1; 412.1; 356 \\
\hline 10 & 31.91 & $465 ; 467$ \\
\hline 11 & 32.60 & $\begin{array}{l}\text { 947; 951; 1007.8; 1009.8; 1027.3***; } \\
\text { 1029.3***; 1041.8; 1051.8; 1573.9**; } \\
\text { 1587.9; 1589.9; 1601.9; 1603.9; 1617.9; } \\
\text { 1619.9; 1668* }\end{array}$ \\
\hline 12 & 35.23 & $\begin{array}{l}\text { 1221.6; 1235.6; 1249.6; 1251.6; 1267.6; } \\
1281.6 ; 2299.6\end{array}$ \\
\hline 13 & 36.62 & $\begin{array}{l}\mathbf{1 0 1 1 . 3 * * ; 1 0 1 3 . 3 * * ; 1 0 2 5 . 3 ; 1 0 2 7 . 3 ; ~} \\
\mathbf{1 5 6 1 . 8}^{*} ; 1398.7 ; 1787.2\end{array}$ \\
\hline 14 & 41.51 & $2819.3 ; \mathbf{2 9 1 8 . 3}$ \\
\hline
\end{tabular}

negrito: sinal mais intenso obtido nos espectros; negrito********: ordem decrescente de intensidade dos sinais obtidos nos espectros.

TOTAL: 32 COMPOSTOS

\subsection{Determinação da estrutura molecular do composto BDS 391}

Após a obtenção de 5,45 mg, em alto grau de pureza, do composto denominado BDS 391 (pico 6, da Figura 2B), procedemos aos ensaios para a determinação estrutural dessa molécula. É importante frisar que nessa etapa do trabalho, para a determinação estrutural de uma molécula, necessitam-se quantidades dessa ordem para que se possam obter espectros com qualidade suficiente para a interpretação.

Inicialmente, os experimentos no equipamento ESI Q-Tof API Ultima (Micromass, UK) mostraram claramente dois picos de massa molecular com $(\mathrm{M}+\mathrm{H})+$ em 391 e 393, demonstrando 
que a molécula contem um átomo de bromo (Figura 3). A fórmula molecular foi determinada por HR-MS como $\mathrm{C}_{16} \mathrm{H}_{15} \mathrm{~N}_{4} \mathrm{O}_{3} \mathrm{Br}\left[\mathrm{m} / z 391.0410(\mathrm{M}+\mathrm{H})^{+}\right.$, calculada para $\mathrm{C}_{16} \mathrm{H}_{15} \mathrm{~N}_{4} \mathrm{O}_{3} \mathrm{Br}$ 391.0406] (dados não mostrados).

O espectro de UV sugeriu a presença de um núcleo indol, uma vez que mostrou padrão típico de absorbância deste tipo de estrutura, em $\lambda_{\max } 285 \mathrm{~nm}$ ( $\varepsilon$ 5600), com um ombro em 294 nm (Figura 4). A análise dos espectros de fragmentação MS/MS (Figura 5) dos íons 391 e 393 mostrou a presença de uma histidina $(\mathrm{m} / \mathrm{z}, 110$ e 156), indicando, portanto, que o núcleo indol na verdade é um ácido acético bromoindol (Figura 6).

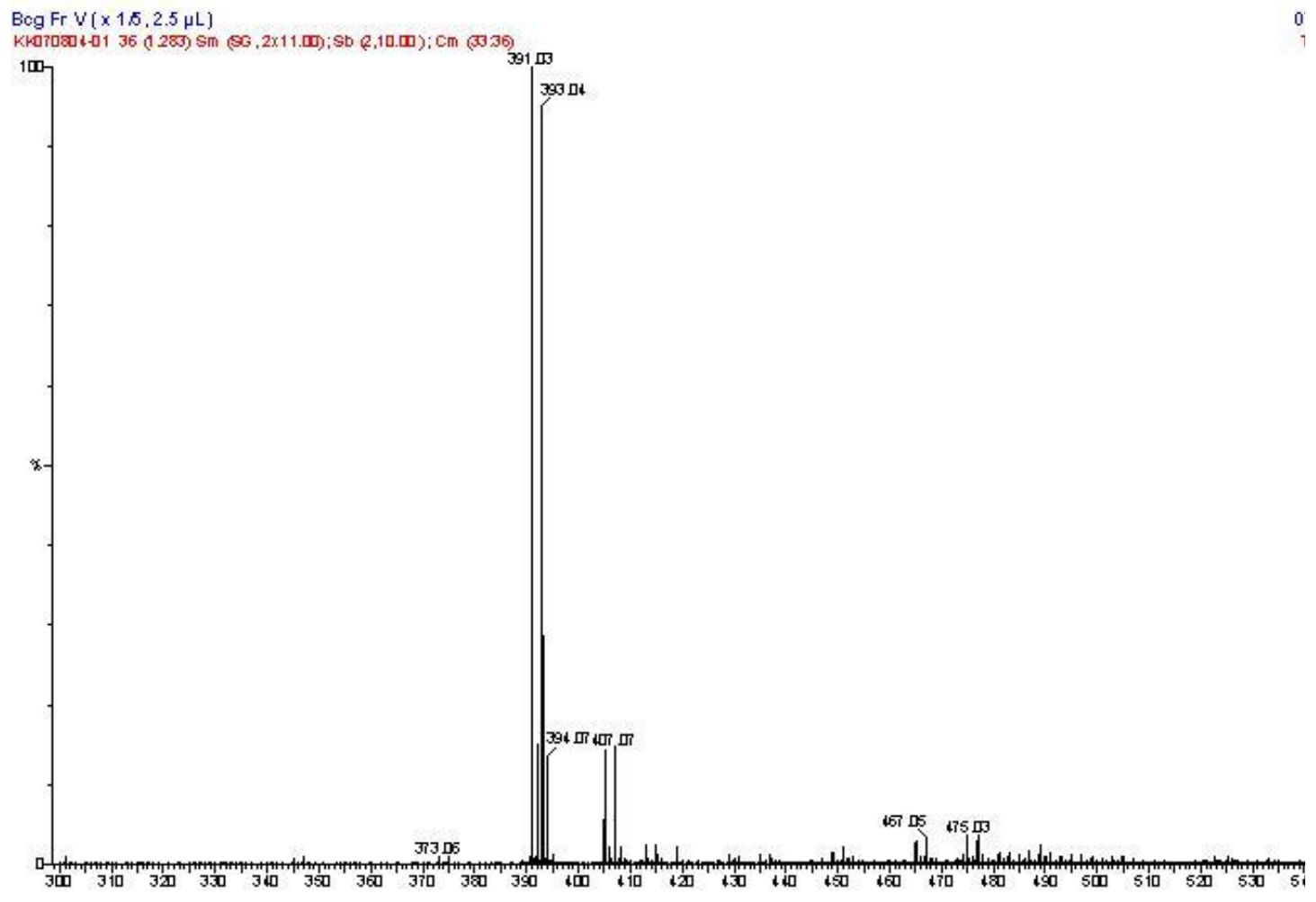

Figura 3: Espectro ESI-MS de BDS 391. Como a amostra provinha apenas de uma etapa de purificação em HPLC, observa-se contaminantes de BDS 405 e BDS 465 unidades de massa. 
Results 53

Resultados

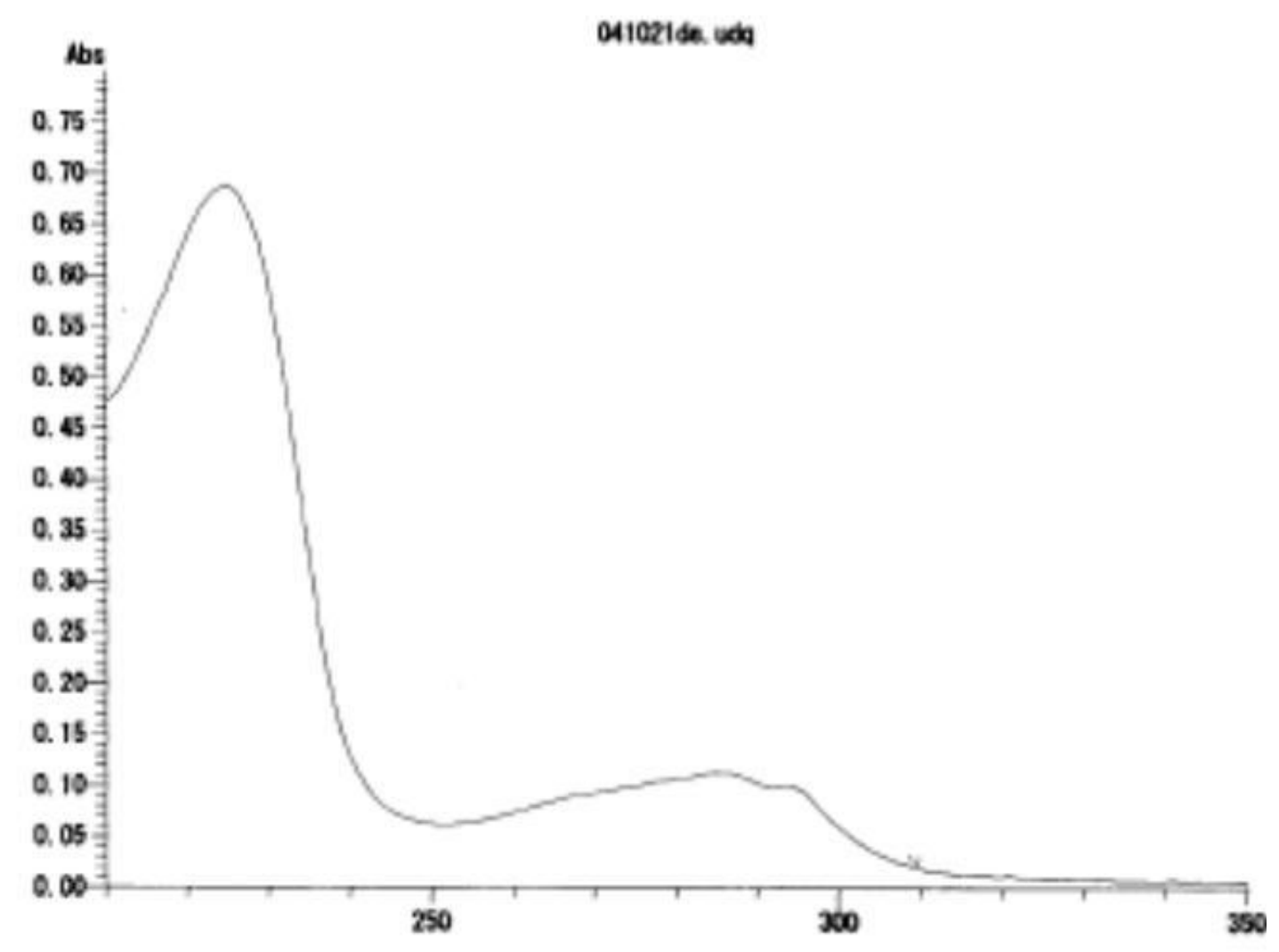

Figura 4: Varredura de absorbância do BDS 391 em Espectro de UV. Para auxiliar a caracterização estrutural do BDS 391, foi realizado uma varredura do espectro de absorção em UV. 
\begin{tabular}{l|l} 
Results & 54
\end{tabular}

Resultados

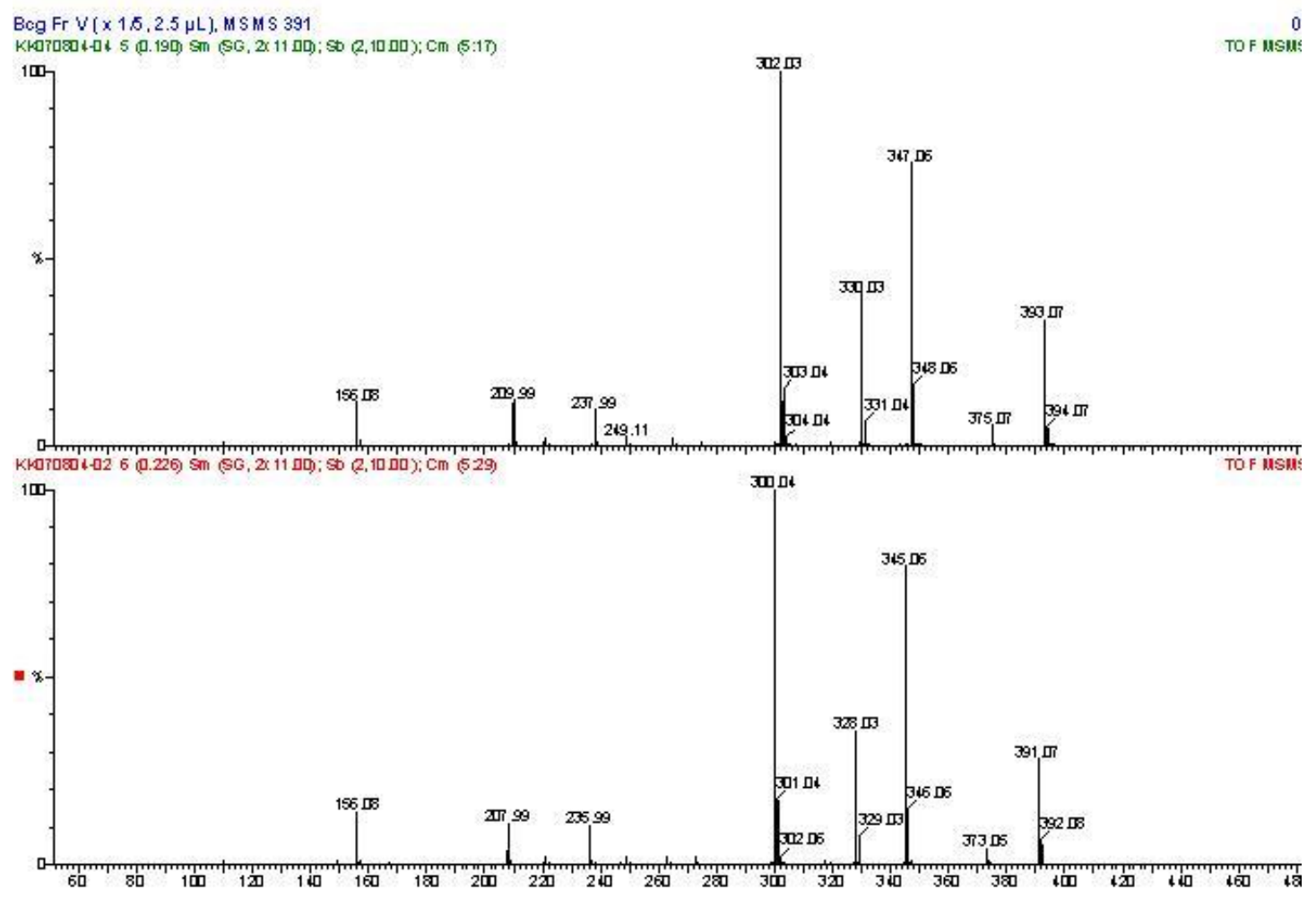

Figura 5: Espectro de fragmentação MS/MS dos íons BDS 391 e BDS 393, mostrando o "íon-filho" de $\mathrm{m} / z, 156.08$ em comum (histidina). Intensidades arbitrárias de argônio de 15 a 35\% foram utilizadas na fragmentação. 
<smiles>NC(=O)Cc1c[nH]c2cc(Br)ccc12</smiles>
$m / z 391(M+H)^{+}$<smiles>CCCC</smiles><smiles>C#CCc1c[nH]c2cc(Br)ccc12</smiles>

$m / z 236$<smiles>[CH2]c1c[nH]c2cc(Br)ccc12</smiles>

$m / z 208$<smiles>NC(Cc1c[nH]cn1)C(=O)O</smiles>

$m / z 156$<smiles>N=CCc1c[nH]cn1</smiles>

$m / z 110$
$\stackrel{-\mathrm{H}_{2} \mathrm{O}}{\longrightarrow}$<smiles>C/C=C\CC([18OH])NC(=O)Cc1c[nH]c2cc(Br)ccc12</smiles>

$m / z 373$<smiles>C=CCC=NC(=O)Cc1c[nH]c2cc(Br)ccc12</smiles>

$m / z 345$

Figura 6: Análise estrutural dos fragmentos obtidos pela irradiação, com argônio, da molécula BDS 391, As estruturas mostradas acima correspondem aos "íns-filhos" detectados por espectrometria de massa, apresentados na Figura 5.

\subsection{Caracterização estrutural do BDS 391 por meio de analises de RMN e HR-MS}

Esta etapa foi realizada em colaboração com o professor Dr. Katsuhiro Konno. Os estudos foram iniciados junto ao Centro de Toxinologia Aplicada (CAT/CEPID/FAPESP) no Instituto Butantan, e posteriormente, no Instituto de Medicina Natural da Universidade de Toyama, Japão, após a transferência do Dr. Konno para esta universidade. Os experimentos de ressonância magnética nuclear (RMN) foram executados em espectrômetro JEOL ALPHA 400 (em 400MHz) com a amostra dissolvida em $\mathrm{D}_{2} \mathrm{O}$. Os "chemical shifts" são expressos em ppm e relativos ao tetrametilsilano (TMS). Espectros de massa de alta resolução (HR-MS), para fim de determinação da massa elemental do composto, foram executados em espectrômetro tipo JEOL DMX 500. 
Os espectros de RMN suportam os resultados mostrados anteriormente e análises posteriores de RMN bidimensional levaram à determinação da estrutura completa, que se encontra sumarizada na Figura 7. A presença de uma histidina foi estabelecida pelos sinais de ${ }^{1} \mathrm{H}$ NMR em 3.08, 3.30, 4.76, 6.88 e 8.29 ppm, correlacionando com os sinais de ${ }^{13} \mathrm{C}$ NMR em 26.2, 51.6, 116.8, 128.7, 133.0 e 173.9. Similarmente, a presença de ácido bromoindolacético foi estabelecida pelos sinais de ${ }^{1} \mathrm{H}$ NMR em 3.67, 3.76, 7.23, 7.28, 7.31 e 7.71, correlacionando com os sinais de ${ }^{13} \mathrm{C}$ NMR em 32.4, 108.0, 114.7, 114.9, 119.7, 122.4, 125.5, 125.7, 137.1 e 174.8. A posição do bromo no anel indol foi determinada por experimentos de HMBC.

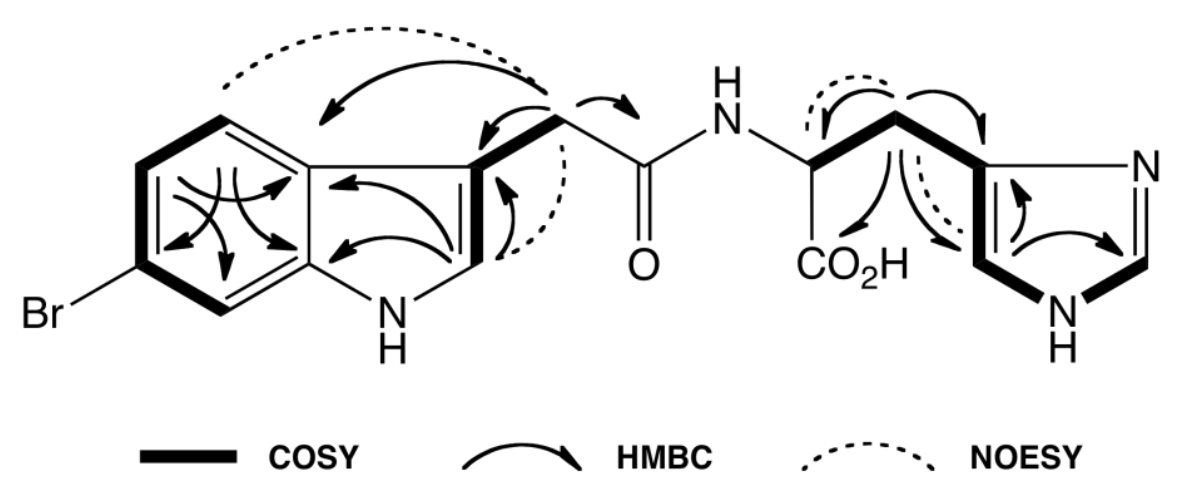

Figura 7: Análise estrutural de BDS 391 por Ressonância Nuclear. Magnética

\subsection{Determinação de letalidade ou de atividade paralisante do composto BDS 391}

Para avaliar a eventual toxicidade do BDS 391, realizamos testes para determinação de atividade letal ou paralisante sobre crustáceos, de acordo com o método descrito na literatura (Honma e Shiomi, 2005, Honma et al., 2005). A toxina BcIII, uma típica toxina que afeta canais para $\mathrm{Na}^{+}$dependentes de voltagem, e a toxina $\mathrm{BcIV}$, uma toxina pertencente à nova classe de toxinas que atuam especificamente em correntes de $\mathrm{Na}^{+}$de crustáceos (Oliveira et al., 2004, 2006), isoladas desta mesma anêmona (Fração III), foram usadas como controle positivo nesses experimentos, para se observar a diferença de efeitos e de potência entre os peptídeos e o composto BDS 391. Na Tabela 2, estão apresentados os resultados obtidos nestes ensaios. Das 
toxinas aqui apresentadas, algumas não puderam ter sua dose letal (DL50) ou dose efetiva (DE50) determinadas, por falta de material. A dose de $2000 \mu \mathrm{g} / \mathrm{Kg}$ foi a dose máxima das toxinas empregadas neste estudo (Tabela 2).

Tabela 2- Efeitos paralisantes e letais de toxinas isoladas da fração III (FrIII) da peçonha de B.cangicum e do composto bromado BDS 391, injetadas in vivo em crustáceos. +++, ++, +: efeitos fortes, moderados e fracos para paralisia e +: presença de letalidade. Para cada composto, um número de pelo menos 4 animais foi injetado, na concentração apontada.

\begin{tabular}{|c|c|c|c|}
\hline Composto & $\begin{array}{l}\text { Concentração } \\
\text { máxima empregada } \\
(\mu \mathrm{g} / \mathrm{kg})\end{array}$ & Paralisia & Letalidade \\
\hline Bcg21.00 & 500 & +++ & - \\
\hline Bcg28.19 & 2000 & + & - \\
\hline Bcg28.78 & 2000 & - & - \\
\hline Bcg29.21 & 2000 & - & - \\
\hline $\mathrm{BcIV}$ & 1000 & $\begin{array}{c}+++ \\
(C E 50 \sim 750 \mu g / k g)\end{array}$ & - \\
\hline BcIII & 800 & +++ & $\begin{array}{c}+ \\
(D L 50 \sim 230 \mu g / k g\end{array}$ \\
\hline BDS 391 & 2000 & - & - \\
\hline
\end{tabular}

\subsection{Efeito do composto BDS 391 sobre a hiperalgesia induzida por prostaglandina $E_{2}\left(P_{G} E_{2}\right)$}

O BDS 391 foi injetado por via intraplantar (i.pl.), 150min após a administração da PGE $_{2}$ e os animais foram avaliados, no teste de pressão de patas, antes e 180min após a administração da $\mathrm{PGE}_{2}$. Os resultados mostram que a $\mathrm{PGE}_{2}$ acarretou hiperalgesia, representada pela diminuição do limiar nociceptivo, quando comparado com a medida basal, obtida antes de qualquer tratamento. Salina ou salina mais a proporção de etanol utilizada para diluir $\mathrm{PGE}_{2}$, administrada por via intraplantar, não alterou a hiperalgesia acarretada pela $\mathrm{PGE}_{2}$ (dados não mostrados). $\mathrm{O}$ composto BDS 391, na dose de $150 \mathrm{nM}$, reverteu a hiperalgesia e também acarretou aumento do 
limiar nociceptivo, em relação a medida basal (Figura 8).

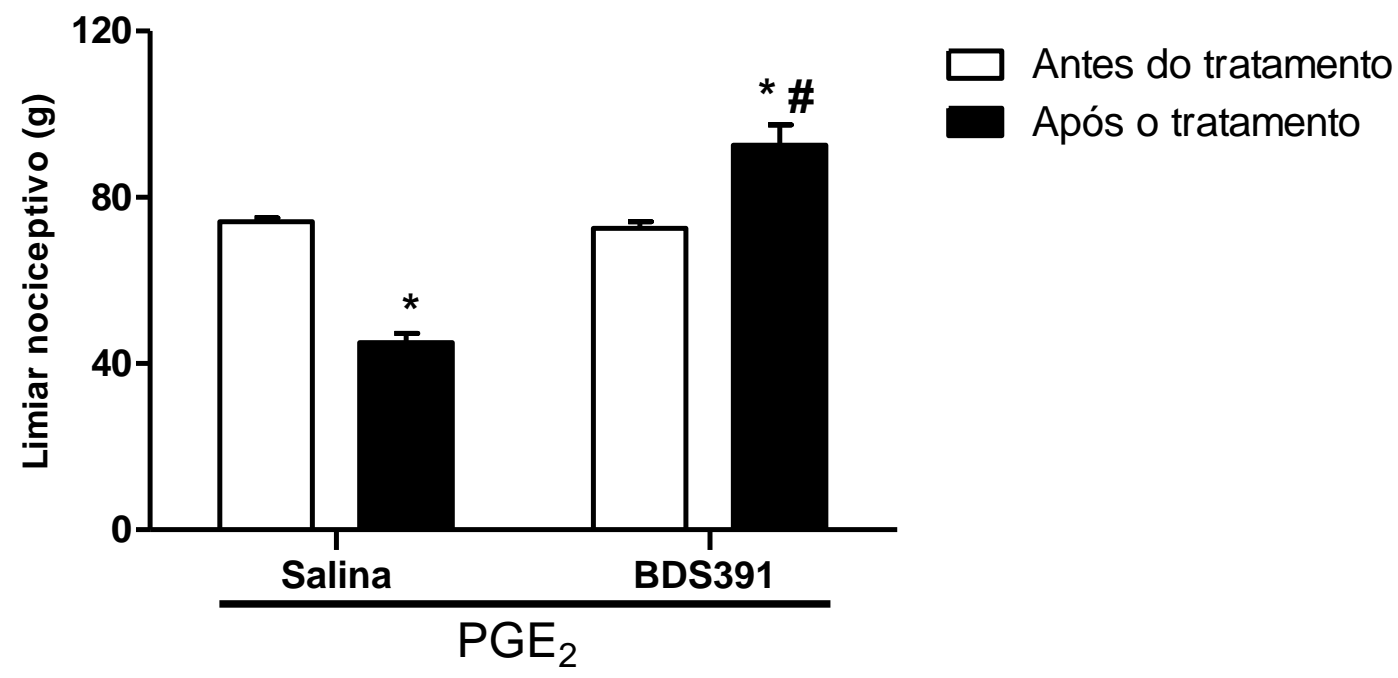

Figura 8: Efeito do BDS 391 sobre a hiperalgesia induzida por prostaglandina $\mathrm{E}_{2}\left(\mathrm{PGE}_{2}\right)$. A sensibilidade dolorosa dos animais foi avaliada pelo teste de pressão da pata de ratos. Para a indução de hiperalgesia, os animais foram tratados com Prostaglandina $E_{2}$ (100 ng/pata). O BDS 391, na dose de $150 \mathrm{nM}$, foi administrado por via i.pl. 150 min após a $\mathrm{PGE}_{2}$. Como controle foi utilizada salina. O teste de pressão de patas foi aplicado antes e 180 min após a administração de $\mathrm{PGE}_{2}$ *p $<0,05$ por comparação com a medida antes do tratamento, $\# \mathrm{p}<0,05$ por comparação com o grupo salina. $\mathrm{N}=7$. 


\subsection{Efeito do BDS 391 sobre a hiperalgesia e alodinia causada pela ligadura do nervo isquiático de ratos $(\mathrm{CCI})$ :}

A constrição do nervo isquiático (CCI) acarretou diminuição do limiar de dor dos animais, em relação à medida basal (linha tracejada, Figura 9A), caracterizando o fenômeno de hiperalgesia. Este fenômeno foi detectado no sétimo dia após a cirurgia (dados não mostrados) e se manteve até o $14^{\circ}$ do pós-operatório. A ligação do nervo isquiático provocou também diminuição na intensidade do estímulo tátil necessário para induzir a resposta de retirada da pata, quando comparado à medida basal (linha tracejada, Figura 9B), caracterizando o fenômeno de alodinia. Este fenômeno foi também detectado na $7^{\circ}$ dia após a cirurgia (dados não mostrados) e se manteve até o $14^{\circ}$ dia do pós-operatório.

O BDS 391 foi administrado no $14^{\circ}$ dia após a cirurgia, nas doses de $150 \mathrm{nM} ; 1,5$ e 150 $\mu \mathrm{M}$. Os resultados demonstram que o BDS 391 reverteu parcialmente, nas doses $150 \mathrm{nM}$ e 1,5 $\mu \mathrm{M}$ e totalmente, na dose $150 \mu \mathrm{M}$ a hiperalgesia induzida pela CCI (Figura 9A). Ainda, a dose de $150 \mu \mathrm{M}$ promoveu aumento significativo do limiar nociceptivo dos animais, em relação à medida basal (linha tracejada, Figura 9A). Os resultados indicam ainda, que o BDS 391, nas doses 1,5 e $150 \mu \mathrm{M}$, inibiu parcialmente a alodinia induzida pela CCI (Figura 9B). Por outro lado, salina, administrada por via intraplantar, não alterou a hiperalgesia e alodinia acarretadas pela cirurgia.

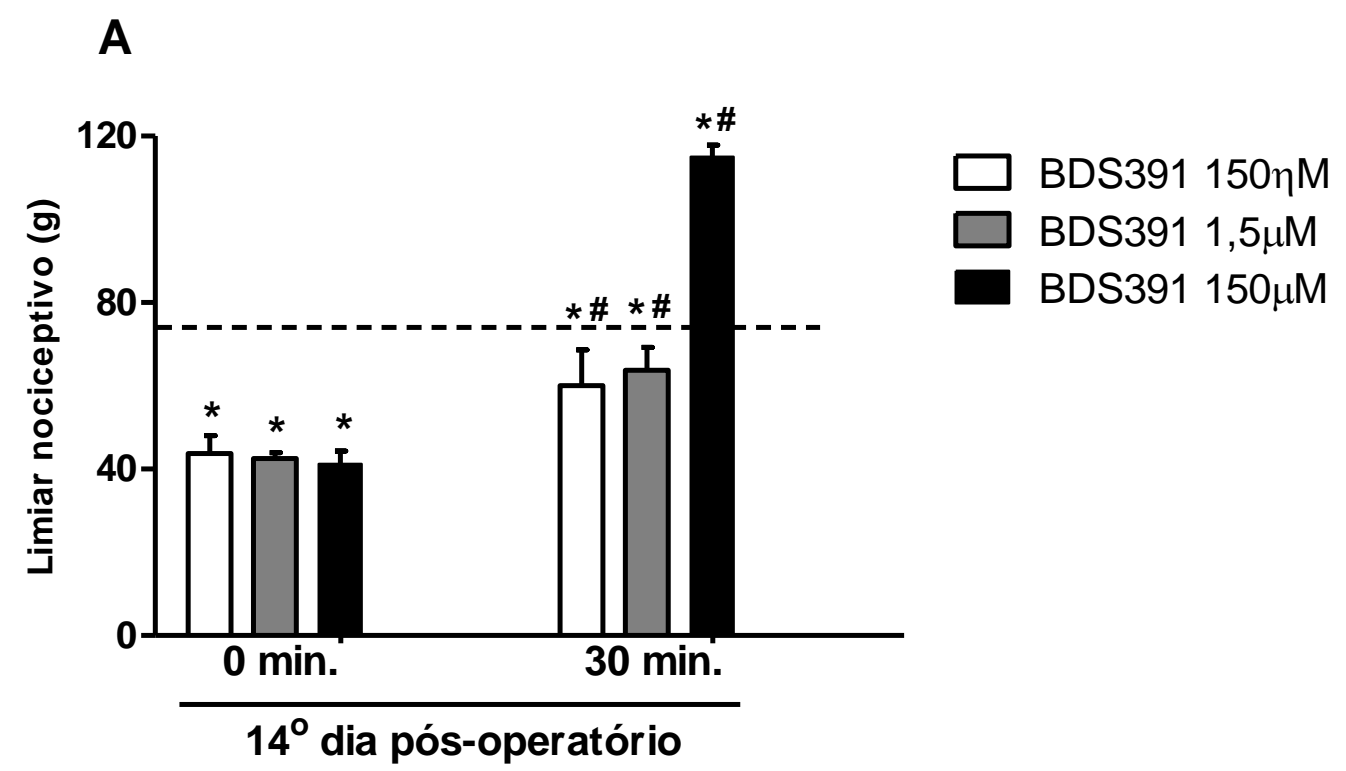




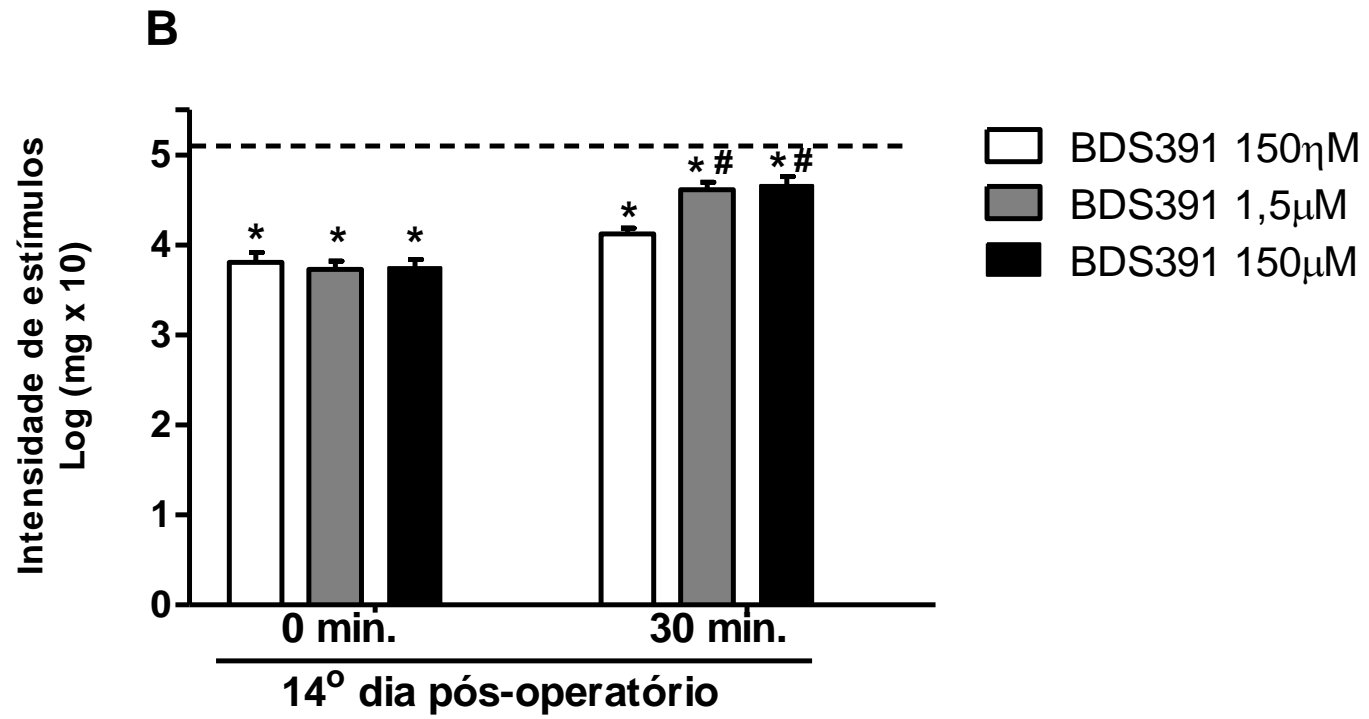

Figura 9: Efeito do BDS 391 sobre a hiperalgesia (8A) e alodinia (8B) induzidas pela ligadura do nervo isquiático de ratos. O tratamento com BDS $391\left(150 \mathrm{nM}, 1,5\right.$ e $150 \mu \mathrm{M}$, i.pl.) foi realizado no $14^{\circ}$ dia pósoperatório. No $14^{\circ}$ dia, as medidas foram realizadas antes (tempo $\left.=0\right)$ e 30 minutos após a administração do BDS 391. Os dados representam a média \pm e.p.m. de 5 animais por grupo. *p $<0,05$ por comparação com a medida basal (linha tracejada), obtida antes da cirurgia. \#p $<0,05$ por comparação com a medida no tempo 0 .

\subsection{Efeito do BDS 391 sobre a nocicepção induzida pela formalina}

Os resultados demonstram que o BDS $391(150 \mathrm{nM}$ e 1,5 $\mu \mathrm{M})$ inibiu, de forma dosedependente, ambas as fases do teste de formalina, ou seja, a fase neurogênica (observada até os 10 minutos após a administração da formalina e a fase inflamatória, observada no período de 20 a 40 minutos após a injeção (Figura 10). Por outro lado, salina, administrada por via intraplantar, não alterou a nocicepção manifesta induzida pela formalina. 


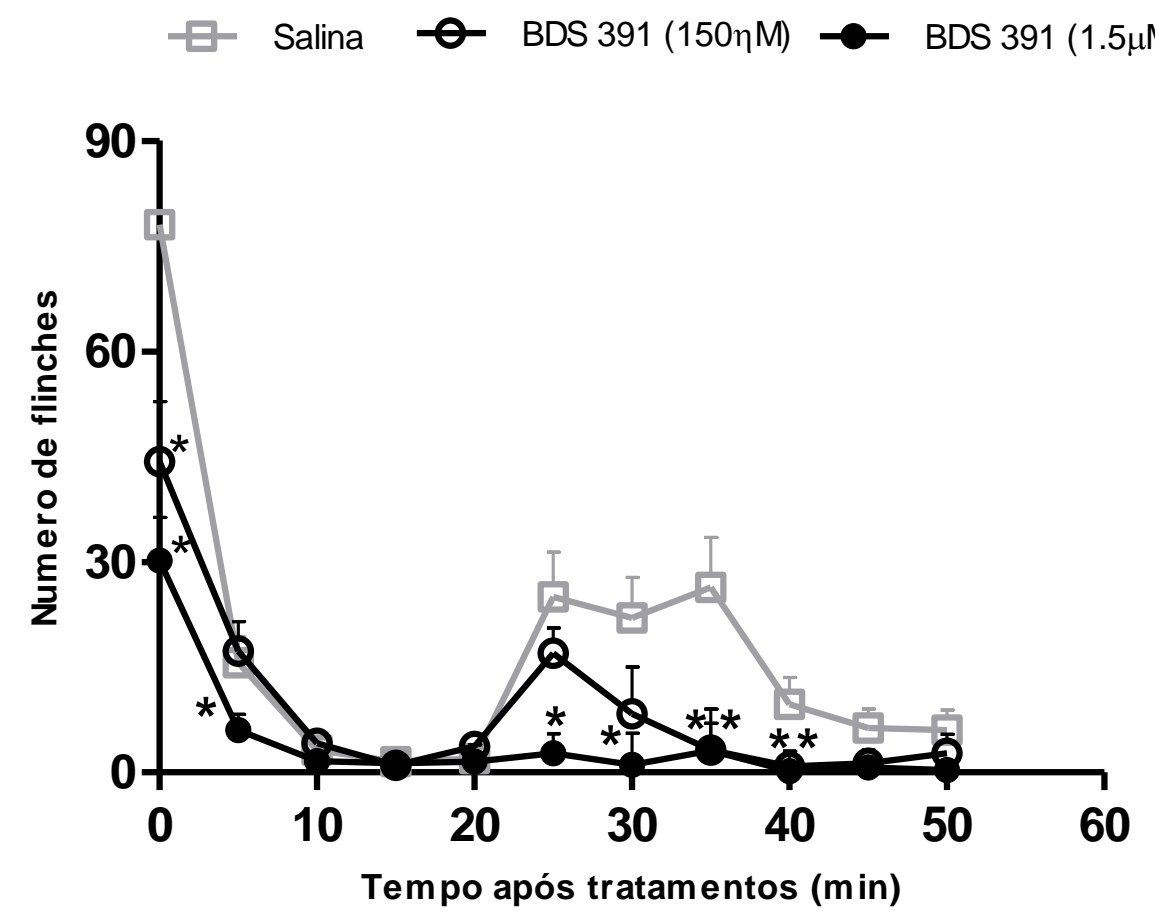

Figura 10: Ação do BDS 391 sobre a nocicepção manifesta induzida por formalina. A nocicepção foi avaliada pelo numero de flinches (resposta) dos animais. A injeção de formalina $1 \%$ induz duas fases distintas de nocicepção - Fase I, nocicepção neurogênica, observada até os 10 minutos iniciais. Fase II, nocicepção inflamatória, observada no período de 20 - 40 minutos. O BDS 391 (150 nM e 1,5 $\mu \mathrm{M}$, i.pl) foi administrado $30 \mathrm{~min}$. antes da formalina. Como controle foi utilizada salina. $* \mathrm{p}<0,05$ por comparação com o grupo salina. $\mathrm{N}=5$.

\subsection{Avaliação da ação periférica (local) do BDS 391}

Nesse experimento procuramos confirmar se a atividade antinociceptiva induzida pelo BDS 391 é decorrente apenas de ação local. Esta ação foi avaliada nos modelos de hiperalgesia induzida por $\mathrm{PGE}_{2}$ e nocicepção acarretada pela injeção de formalina $1 \%$. Nestes experimentos, os agentes nociceptivos foram administrados em uma das patas posteriores (pata direita) e o BDS 391 foi administrado na pata contralateral (pata esquerda). Como controles, foram utilizados animais tratados com salina ou BDS 391, injetados na pata ipsilateral à injeção do irritante. Os resultados mostram que o BDS 391, na maior dose utilizada, quando injetado na pata ipsilateral, reverteu a hiperalgesia induzida pela $\mathrm{PGE}_{2}$ e a nocicepção acarretada pela formalina. Por outro lado, quando administrado na pata contralateral, o composto não interferiu com os fenômenos 
nociceptivos induzidos pela $\mathrm{PGE}_{2}$ e formalina. Estes resultados indicam que nas doses utilizadas, o BDS 391 induz apenas ação antinociceptiva local (Figuras 11 e 12).

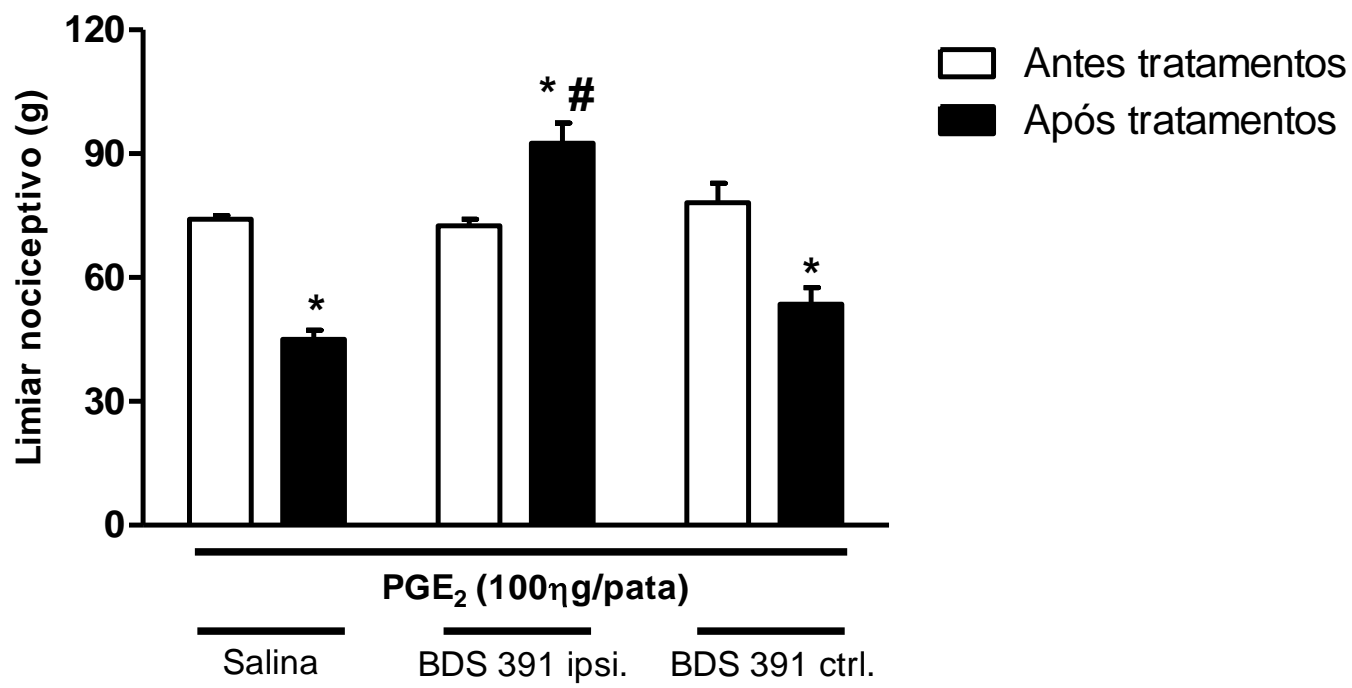

Figura 11: Efeito local do BDS 391 na hiperalgesia induzida por prostaglandina $\mathrm{E}_{2}\left(\mathrm{PGE}_{2}\right)$. A sensibilidade dolorosa dos animais foi avaliada pelo teste de pressão da pata de ratos, aplicado em ambas as patas posteriores dos animai,s antes e tres horas após a injeção de prostaglandina $\mathrm{E}\left(\mathrm{PGE}_{2}, 100 \mathrm{ng} / \mathrm{pata}\right)$. A $\mathrm{PGE}_{2}$ foi injetada apenas em uma das patas posteriores. O BDS 391, na dose de $150 \mathrm{nM}$, foi administrado por via i.pl., na pata ipsi ou contralateral, 150 min. após a $\mathrm{PGE}_{2}$. Como controle, foram utilizados animais tratados com salina na pata ipsilateral. ${ }^{*} \mathrm{p}<0,05$ por comparação com a medida antes do tratamento, $\# p<0,05$ por comparação com o grupo salina. $\mathrm{N}=5$. 


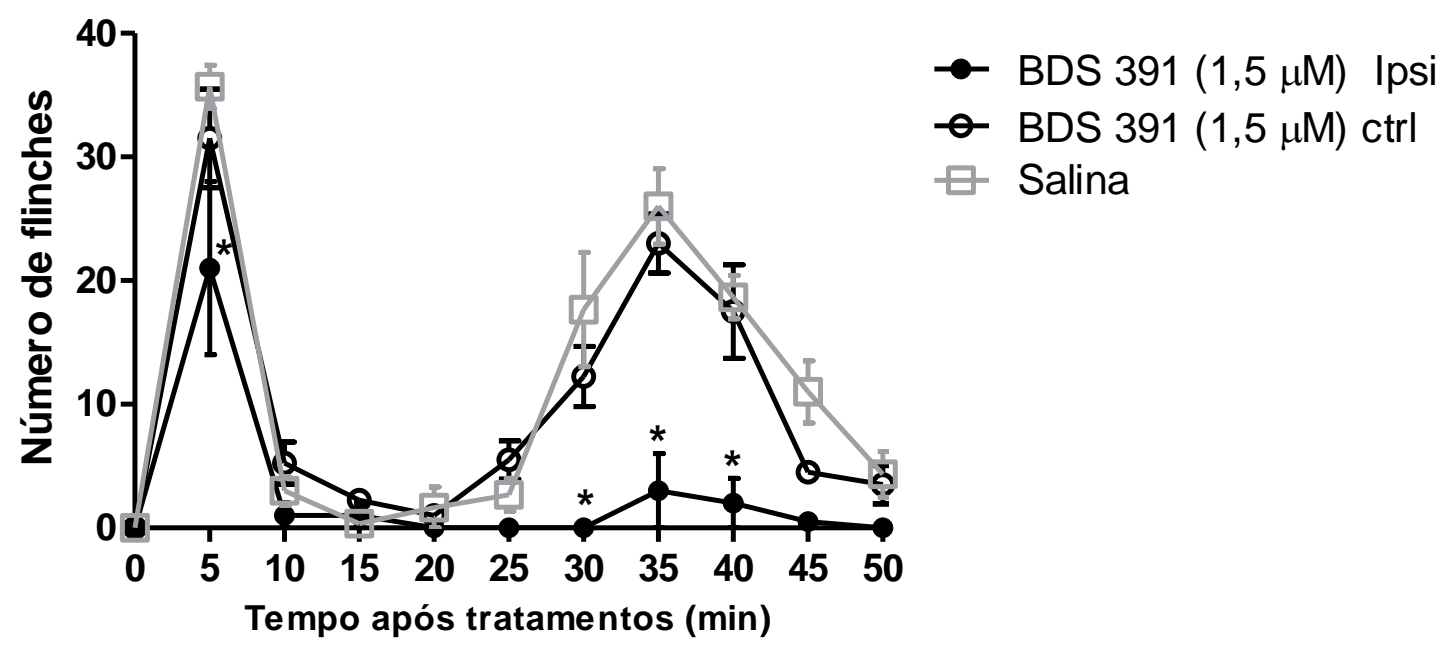

Figura 12: Ação local do BDS 391 sobre a nocicepção manifesta induzida por formalina. A nocicepção foi avaliada pelo numero de flinches (resposta) dos animais. A injeção de formalina $1 \%$ induz duas fases distintas de nocicepção - Fase I, nocicepção neurogênica, observada até os 10 minutos inicais. Fase II, nocicepção inflamatória, observada entre o período de 20 - 40 minutos. O BDS 391, na dose de 1,5 $\mu \mathrm{M}$, foi administrado por via i.pl., 30 minutos antes da formalina. Para avaliar o efeito local do BDS 391, o composto foi administrado na pata ipsi e contralateral à injeção da formalina $1 \%$. Como controle, foram utilizados animais tratados com salina na pata ipsilateral. *p<0,05 por comparação com o grupo salina. $\mathrm{N}$ $=5$.

\subsection{Avaliação do envolvimento dos receptores para histamina e serotonina no efeito do BDS} 391 em modelo de hiperalgesia induzida por $\mathrm{PGE}_{2}$

\subsubsection{Receptores $\mathrm{H}_{1}, \mathrm{H}_{2}$ e $\mathrm{H}_{3}$ para histamina}

Como mencionado na Introdução, dados preliminares indicam que receptores histaminérgicos medeiam o efeito antinociceptivo do BDS 391, quando avaliado no modelo de pressão de patas, na ausência de sensibilização. Para confirmar e melhor caracterizar este mecanismo, o envolvimento destes receptores, no efeito do BDS 391, foi avaliado na vigência de sensibilização por $\mathrm{PGE}_{2}$. Neste estudo, os animais foram pré-tratados com antagonistas seletivos para receptores histaminérgicos $\mathrm{H}_{1}, \mathrm{H}_{2}$ e $\mathrm{H}_{3}$. Os resultados evidenciam que 180min após a administração de $\mathrm{PGE}_{2}$ ocorreu diminuição do limiar nociceptivo dos animais, quando comparado à medida inicial. O BDS $391(150 \mathrm{nM})$ reverteu a hiperalgesia induzida pela $\mathrm{PGE}_{2}$. 
Os antagonistas de receptores histaminérgicos, Pirilamina, SKF e Tioperamida, não interferiram com a ação antinociceptiva do BDS 391 neste modelo de hiperalgesia (Figura 13A, B e C). Os antagonistas per se não interferiram com a hiperalgesia induzida pela $\mathrm{PGE}_{2}$.

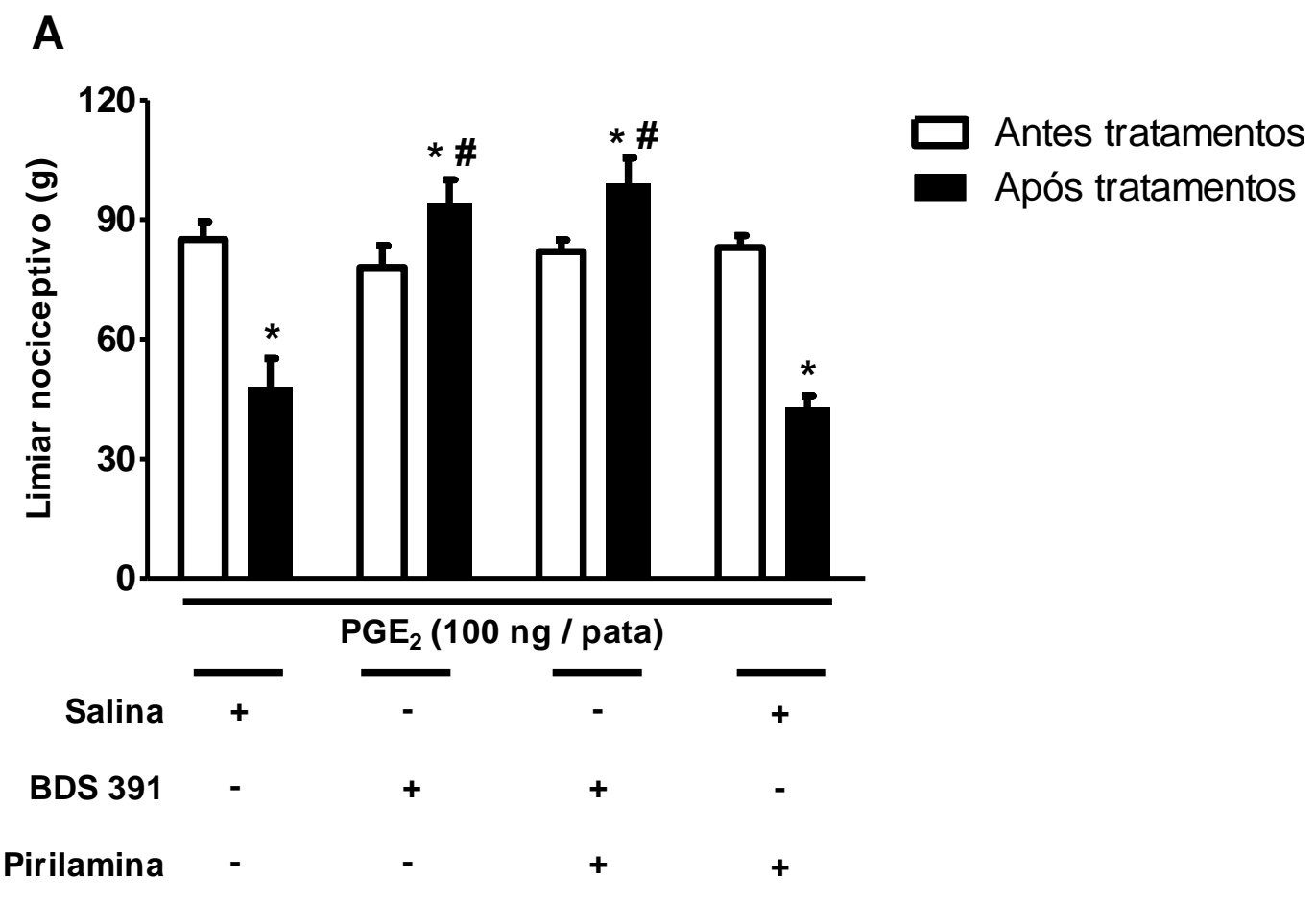

B

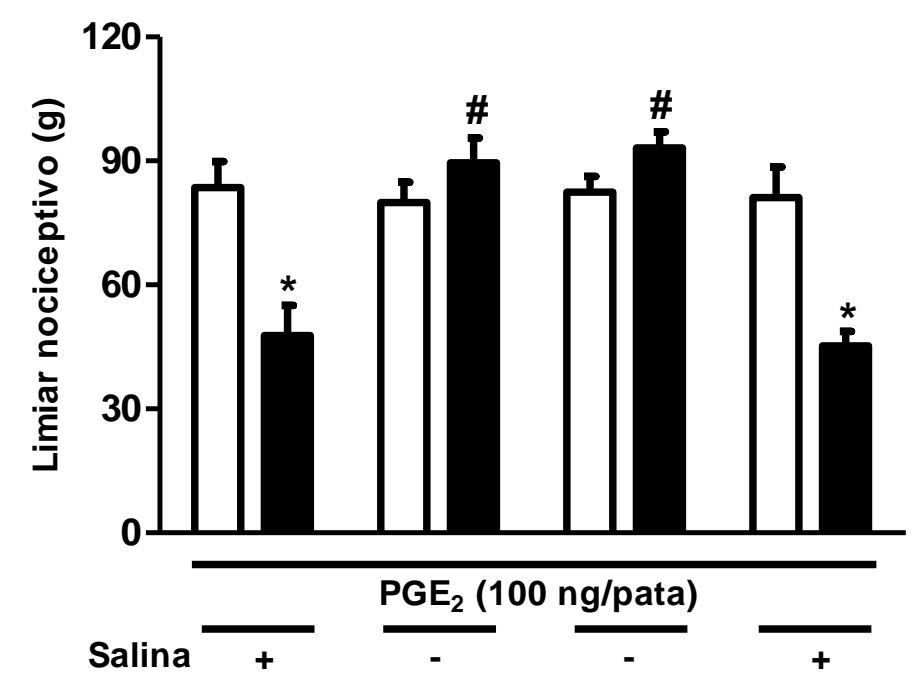

BDS 391

SKF 


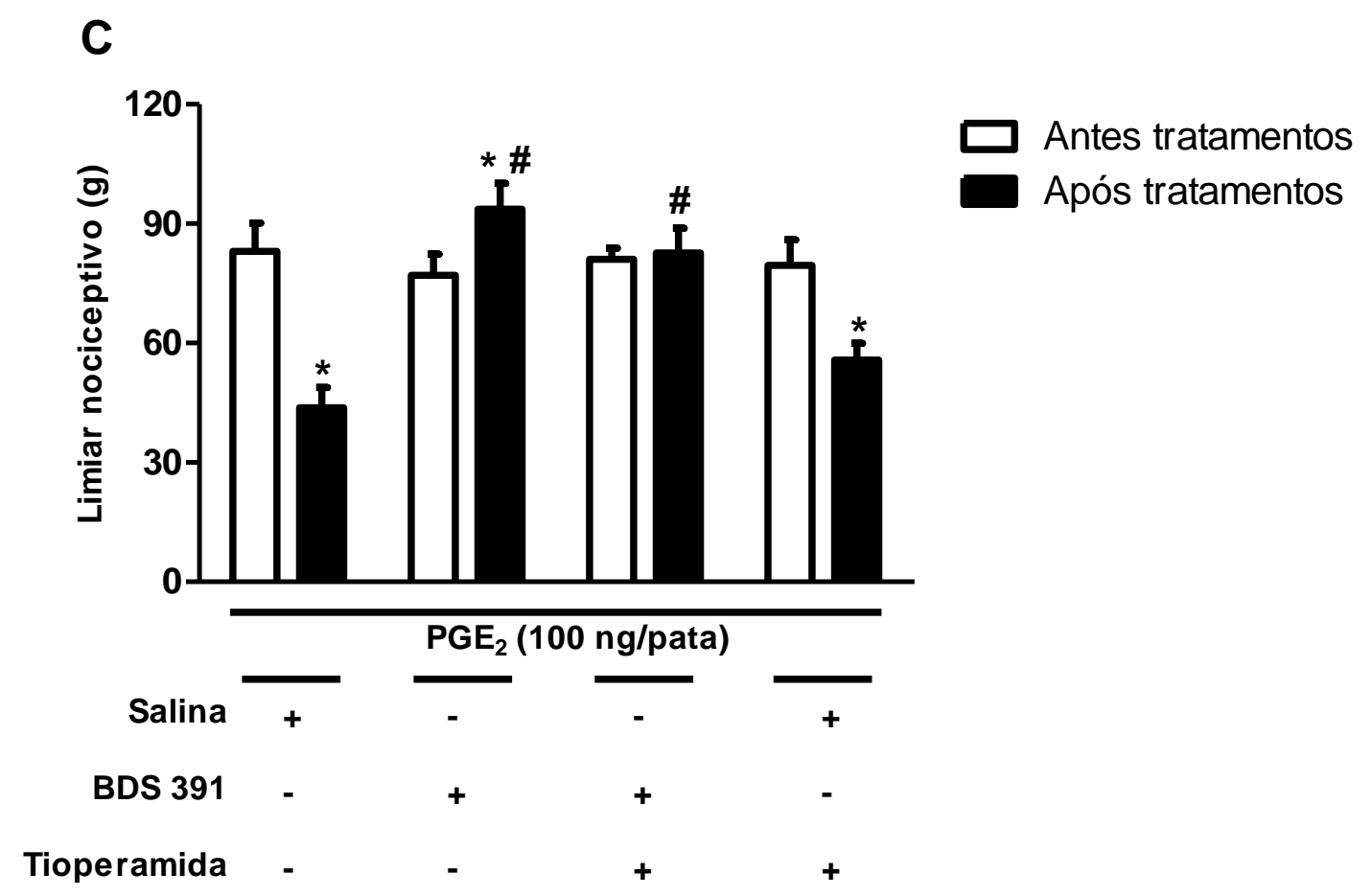

Figura 13: Envolvimento dos receptores para histamina no efeito antinociceptivo do BDS 391, no modelo de hiperalgesia induzida por $\mathrm{PGE}_{2}$. Os ratos foram injetados com os antagonistas Pirilamina, SKF e Tioperamida $(5 \mathrm{mg} / \mathrm{Kg}$, s.c., $300 \mu \mathrm{L})$. Os antagonistas foram administrados 15 minutos antes do BDS 391(150 nM, i.pl) ou salina (i.pl.). As medidas foram realizadas antes (medida inicial) e 180 minutos após a administração da $\mathrm{PGE}_{2}$, utilizando o modelo de pressão de patas. A - Pirilamina $(\mathrm{n}=6), \mathrm{B}-\mathrm{SKF}$ $(\mathrm{n}=6)$ e $\mathrm{C}-$ Tioperamida $(\mathrm{n}=6)$. Os dados representam a média \pm e.p.m. dos animais por grupo. * $\mathrm{p}<0,05$ por comparação com a medida inicial. \# $\mathrm{p}<0,05$ por comparação com o grupo controle (Salina).

\subsubsection{Receptores 5-HT 1 , 5-HT 2 e 5-HT 3 para serotonina}

Dados anteriores mostraram a participação de receptores $5-\mathrm{HT}_{3}$ no aumento do limiar nociceptivo induzido pelo BDS 391, no teste de pressão de patas de ratos, na ausência de sensibilização. A partir destes dados, procuramos, nesta etapa, ampliar a caracterização do mecanismo envolvido na ação antinociceptiva induzida pelo BDS 391, avaliando o envolvimento de receptores serotoninérgicos no efeito do BDS 391 no modelo de hiperalgesia induzida por $\mathrm{PGE}_{2}$. Para tanto, foram utilizados antagonistas seletivos para os receptores $5-\mathrm{HT}_{1 \mathrm{a}}, 5-\mathrm{HT}_{2}$ e 5$\mathrm{HT}_{3}$. As doses dos antagonistas foram determinadas, anteriormente, utilizando agonistas seletivos

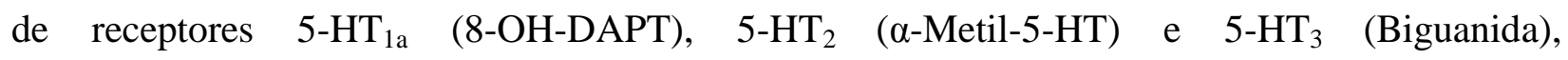
respectivamente, em modelo de nocicepção mecânica (teste de pressão de patas, dados não 
mostrados). Assim, Spiroxatrina, Ketanserina e Ondansetron, antagonistas para 5- $\mathrm{HT}_{1 \mathrm{a}}, 5-\mathrm{HT}_{2} \mathrm{e}$ 5- $\mathrm{HT}_{3}$, respectivamente, foram administrados na dose de $6 \mathrm{mM}$ por via i.pl., 15 minutos antes do BDS $391(150 \mathrm{nM})$. O limiar nociceptivo dos animais foi avaliado antes (medida inicial) e $3 \mathrm{~h}$ (medida final) após a injeção da $\mathrm{PGE}_{2}$. Os resultados mostram que 180min. após a administração de $\mathrm{PGE}_{2}$ ocorreu diminuição do limiar nociceptivo dos animais, quando comparado à medida inicial, acarretando o fenômeno de hiperalgesia (Figuras 14A, B e C). O BDS 391 reverteu a hiperalgesia induzida pela $\mathrm{PGE}_{2}$ e também foi capaz de acarretar aumento do limiar nociceptivo, em relação à medida basal (Figura 14). O antagonista Spiroxatrina, na dose utilizada, não interferiu, per se, com a hiperalgesia induzida pela $\mathrm{PGE}_{2}$ e também não alterou a ação antinociceptiva do BDS 391 (Figura 14A). Por outro lado, os antagonistas Ketanserina e Ondansetron, reverteram, parcial e totalmente, respectivamente, o efeito antinociceptivo do BDS 391. Nenhum dos dois antagonistas alterou, per se, a hiperalgesia acarretada pela $\mathrm{PGE}_{2}$ (Figuras $14 \mathrm{~B}$ e C). 


\section{A}

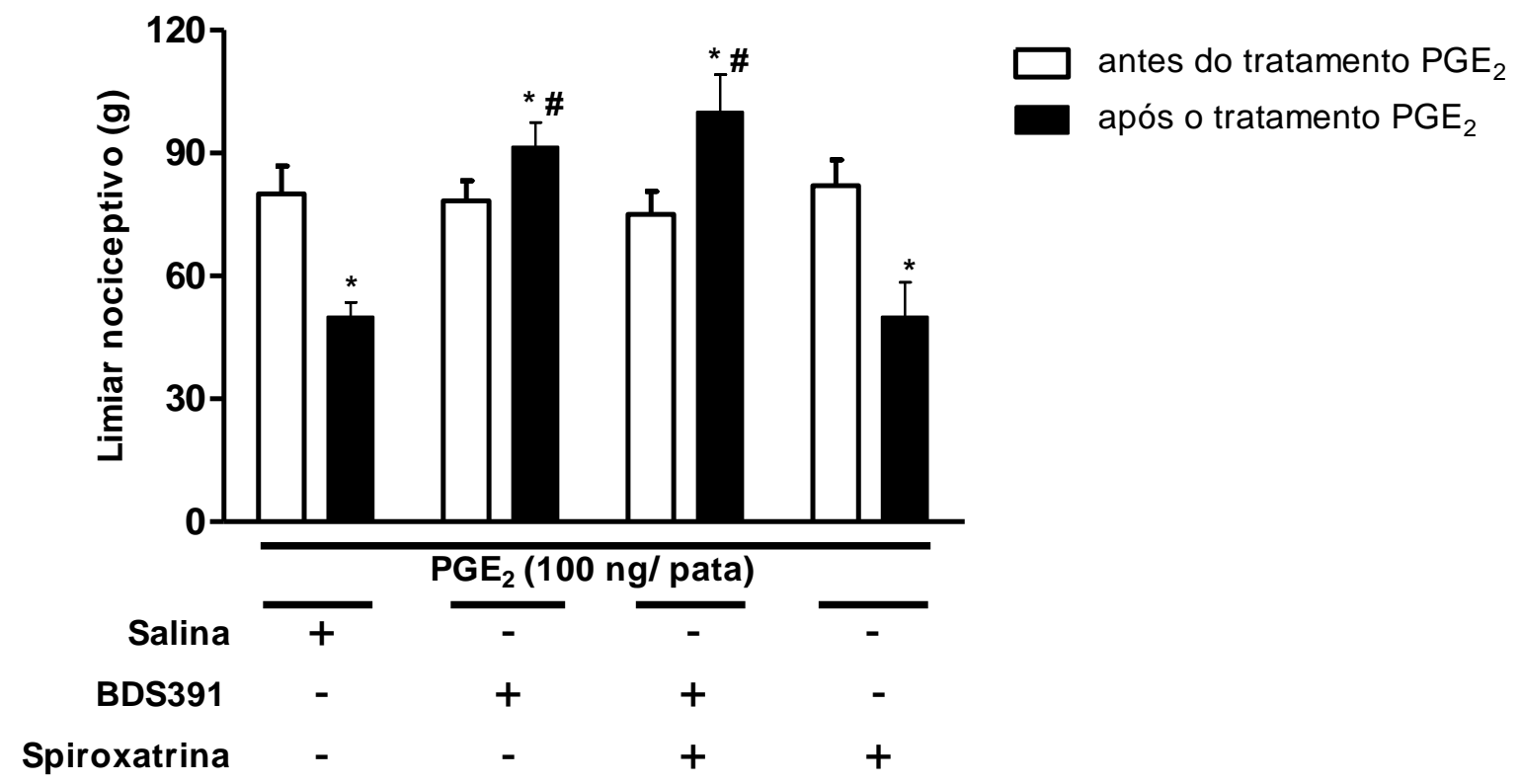

B
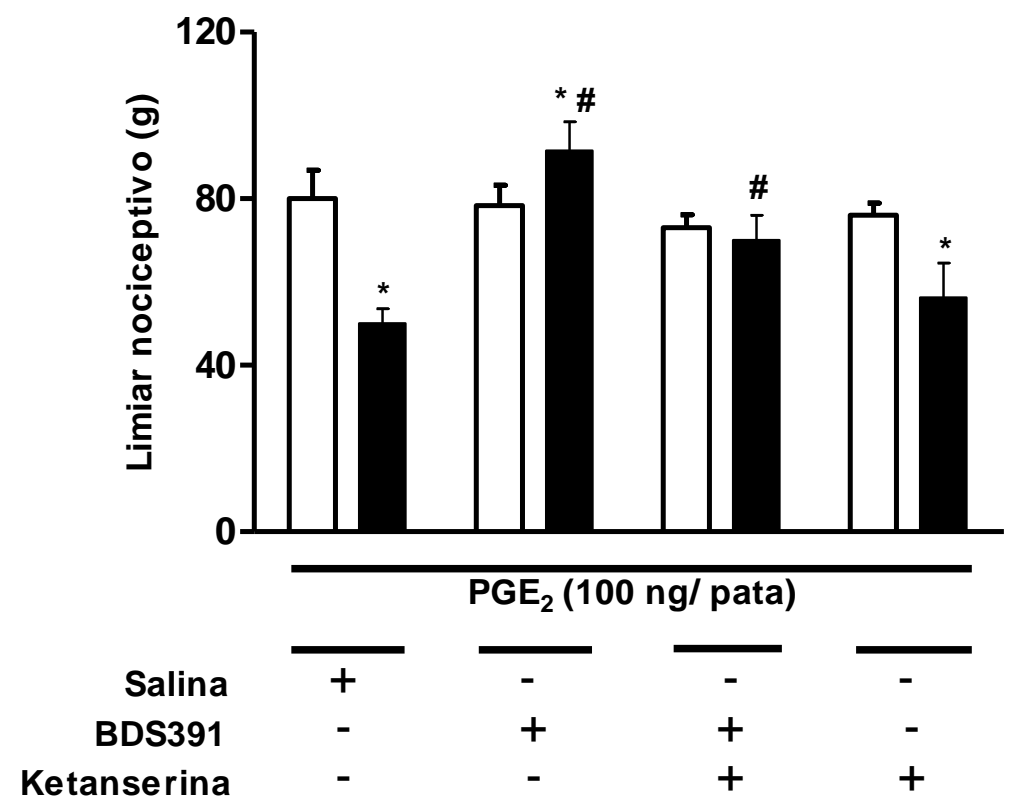
C

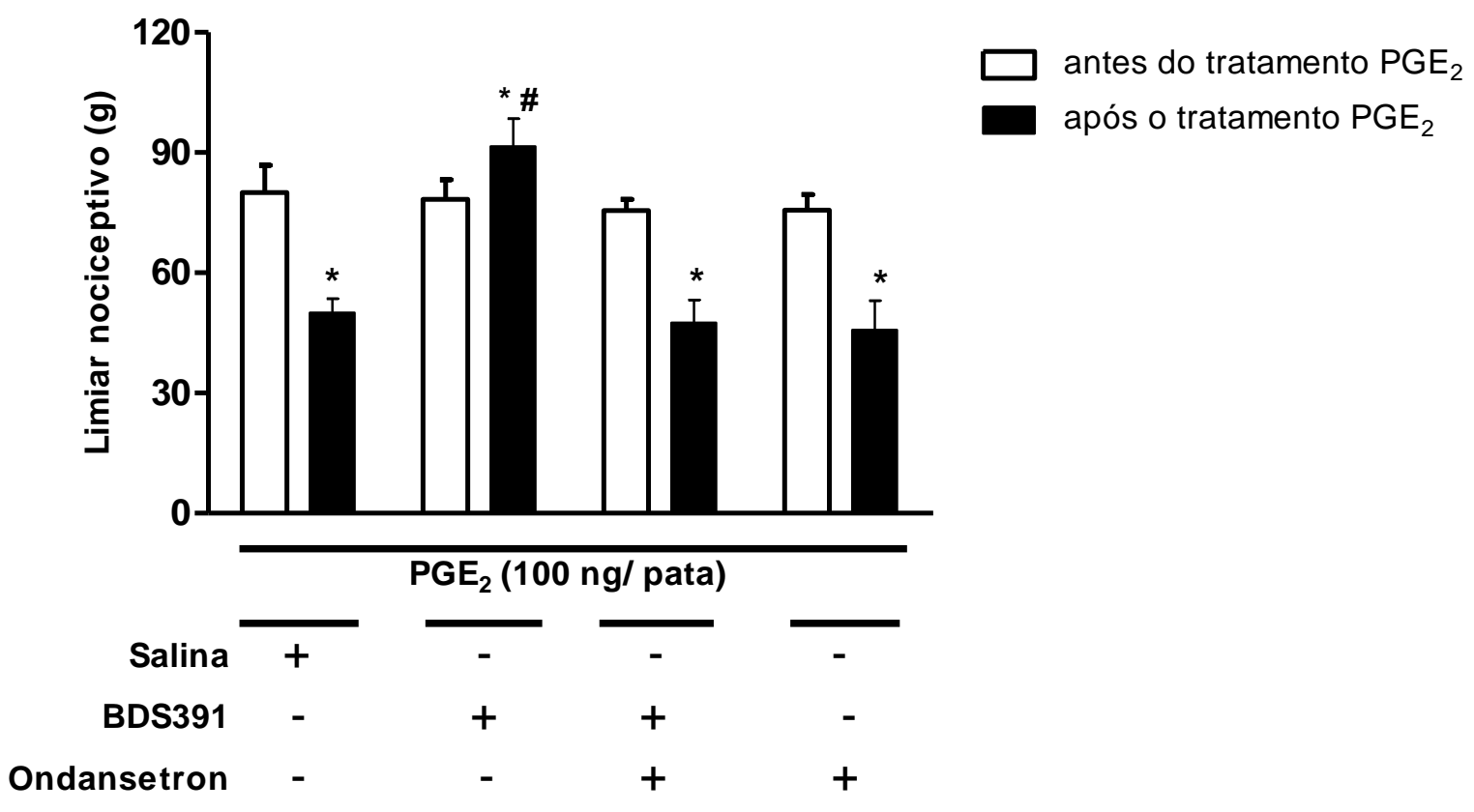

Figura 14: Envolvimento dos receptores para serotonina no efeito analgésico do BDS 391, no modelo de hiperalgesia induzida por $\mathrm{PGE}_{2}$. Os animais foram tratados com os antagonistas Ketanserin, Ondansetron e Spiroxatrine $(6 \mathrm{mM})$ ou salina (controle). Os antagonistas foram administrados 15 minutos antes do BDS 391. Este ultimo, na dose $150 \mathrm{nM}$, foi administrado $150 \mathrm{~min}$. após a $\mathrm{PGE}_{2}(100$ ng/pata). Todas as drogas foram administradas por via intraplantar. Para a avaliação do limiar nociceptivo foi utilizado o teste de pressão de patas. As medidas foram realizadas antes e 180 min após a $\mathrm{PGE}_{2}$. A- Spiroxatrine $(\mathrm{n}=5)$, B- Ketanserin $(\mathrm{n}=5)$ e C- Ondansetron $(\mathrm{n}=8)$. Os dados representam a média \pm e.p.m. dos animais por grupo. \# p<0,05 por comparação com o grupo controle (salina). * $\mathrm{p}<0,05$ por comparação com a medida inicial.

\subsection{Envolvimento dos receptores 5-HT 3 no efeito antinociceptivo do BDS 391 em modelo de dor persistente $(\mathrm{CCI})$}

Com o intuito de ampliar a caracterização do envolvimento dos receptores serotoninérgicos no efeito antinociceptivo induzido pelo BDS 391, foi avaliada, nesta etapa, a participação do receptor 5-HT 3 na ação do BDS 391 em modelo de dor neuropática induzida pela constrição crônica do nervo isquiático de ratos. Os resultados demonstram que o BDS 391, na dose $150 \mu \mathrm{M}$, reverteu a hiperalgesia e inibiu parcialmente a alodina induzidas pela CCI (Figuras 15A e B, respectivamente). O Ondansetron, na dose de $6 \mathrm{mM}$, administrado via i.pl., reverteu o 
efeito antinociceptivo do BDS 391 (Figura 15).

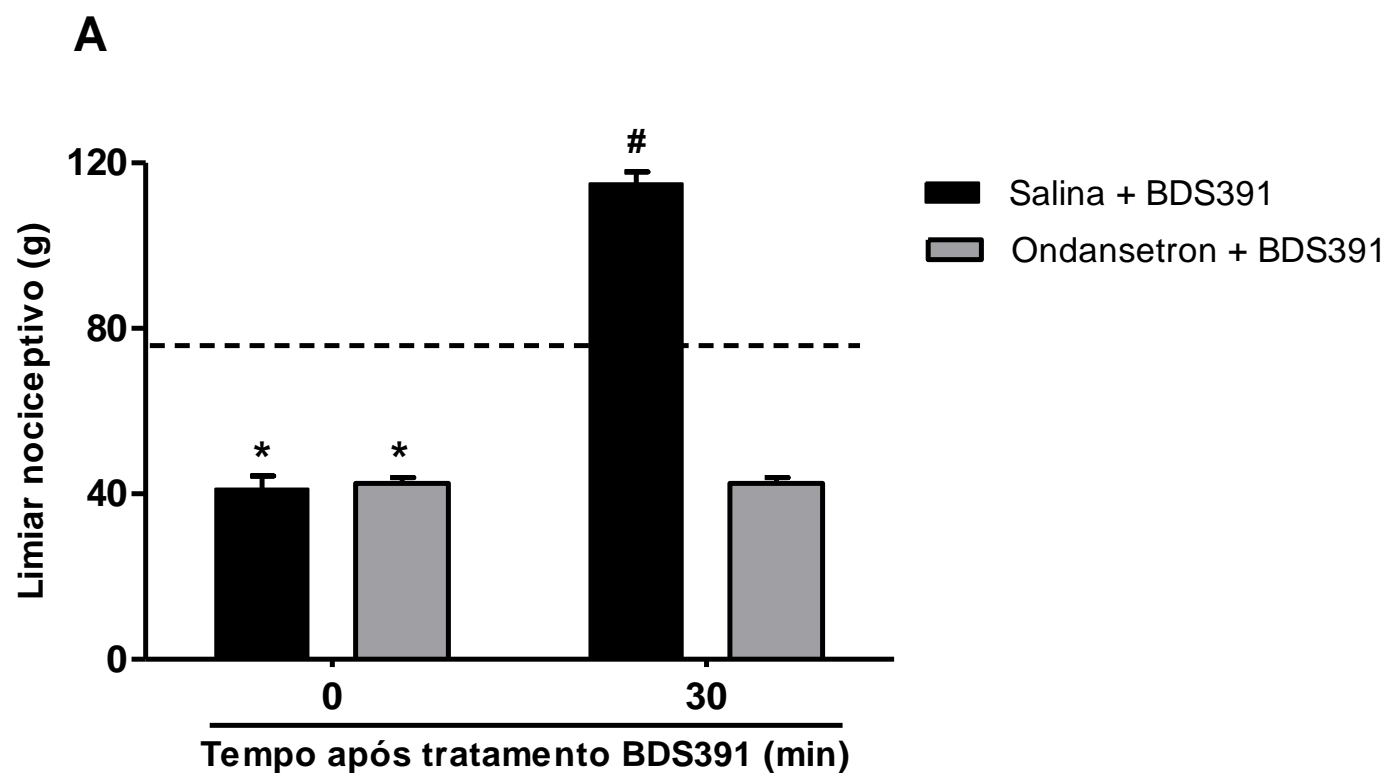

B

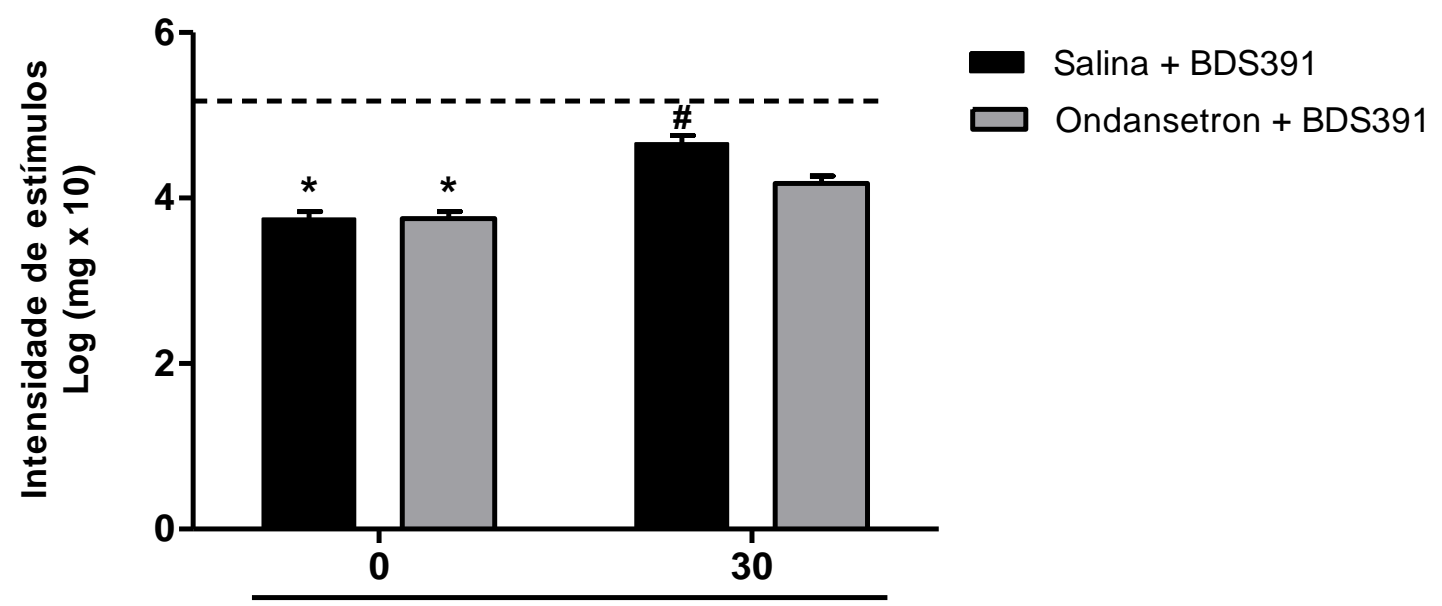

Tempo após tratamento BDS391 (min.)

Figura 15: Envolvimento do receptor 5- $\mathrm{HT}_{3}$ no efeito antinociceptivo induzido pelo BDS $391 \mathrm{em}$ modelo de dor persistente, induzido pela constrição crônica do nervo isquiático de ratos. O tratamento com BDS 391 (150 $\mu \mathrm{M}$, i.pl.) e Ondansetron (6 $\mathrm{mM}$, i.pl.) foi realizado no $14^{\circ}$ dia pós-operatório. No $14^{\circ}$ dia, as medidas foram realizadas antes (tempo 0) e 30 minutos após a administração do BDS 391. O antagonista 5- $\mathrm{HT}_{3}$ foi administrado 15 minutos antes do BDS 391. Como controle, foram utilizados animais tratados com salina, nas mesmas condições experimentais. 14A - Avaliação do hiperalgesia induzida pela CCI, utilizando o teste de pressão de patas. 14B - Avaliação da alodinia induzida pela CCI, utilizando os filamentos de Von frey. Os dados representam a média \pm e.p.m. de 5 animais por grupo. ${ }^{*}$ p $<0,05$ por comparação com a medida inicial (linha tracejada), obtida antes da cirurgia. \#p < 0,05 por comparação com o grupo Ondansetron + BDS 391. 


\subsection{Envolvimento do receptor 5-HT ${ }_{3}$ no efeito antinociceptivo do BDS 391 em modelo de dor manifesta induzida pela formalina}

Neste teste, foi avaliada a participação do receptor $5-\mathrm{HT}_{3}$ na antinocicepção induzida pelo BDS 391 em modelo de dor manifesta. Os resultados indicam que o BDS 391 (1,5 $\mu \mathrm{M}$, i.pl.) reverteu parcialmente a resposta nociceptiva da formalina na fase 1 (Figura 16A) e na fase 2 (Figura 16B). A administração do ondansetron (6 mM, i.pl.) inibiu o efeito antinociceptivo do BDS 391 detectado em ambas a s fases da nocicepção acarretada pela formalina (Figura 16).

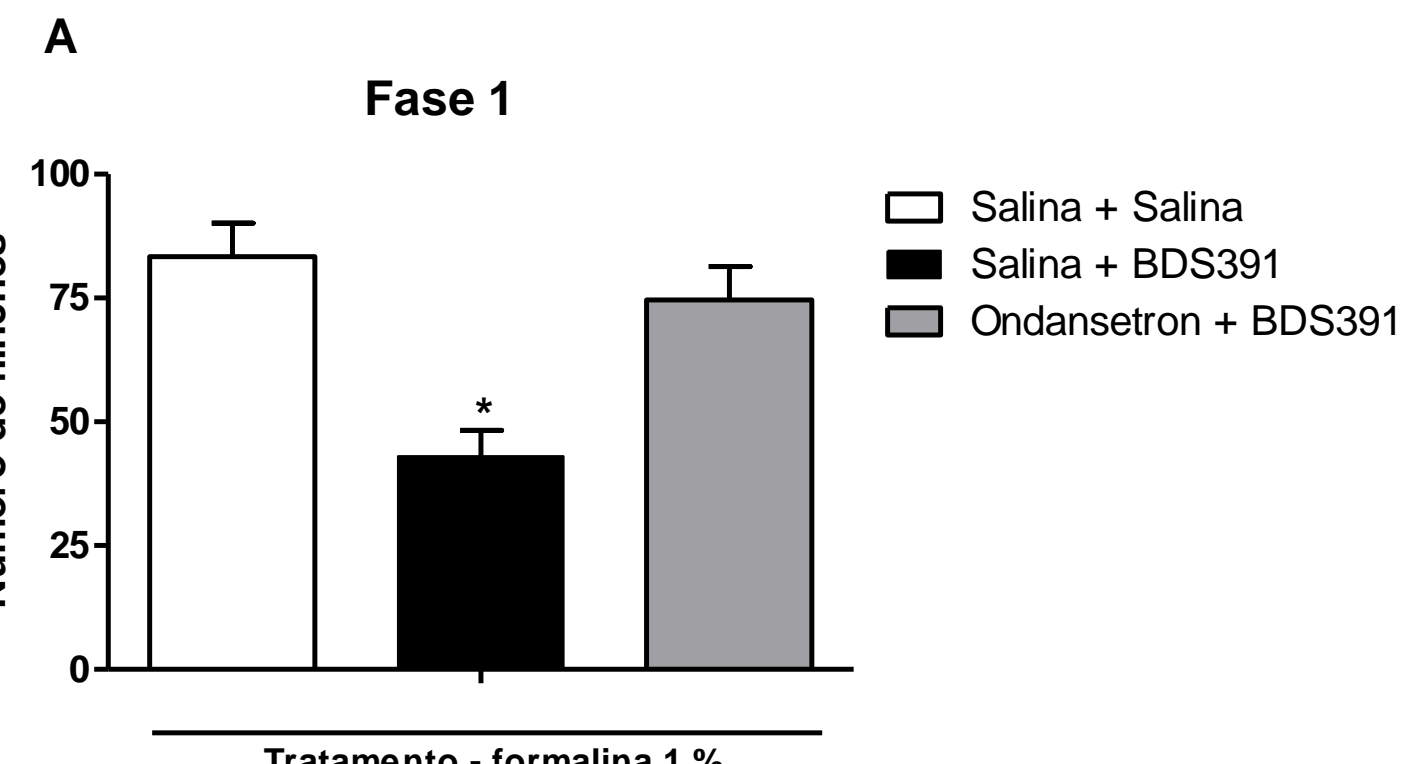


B

\section{Fase 2}

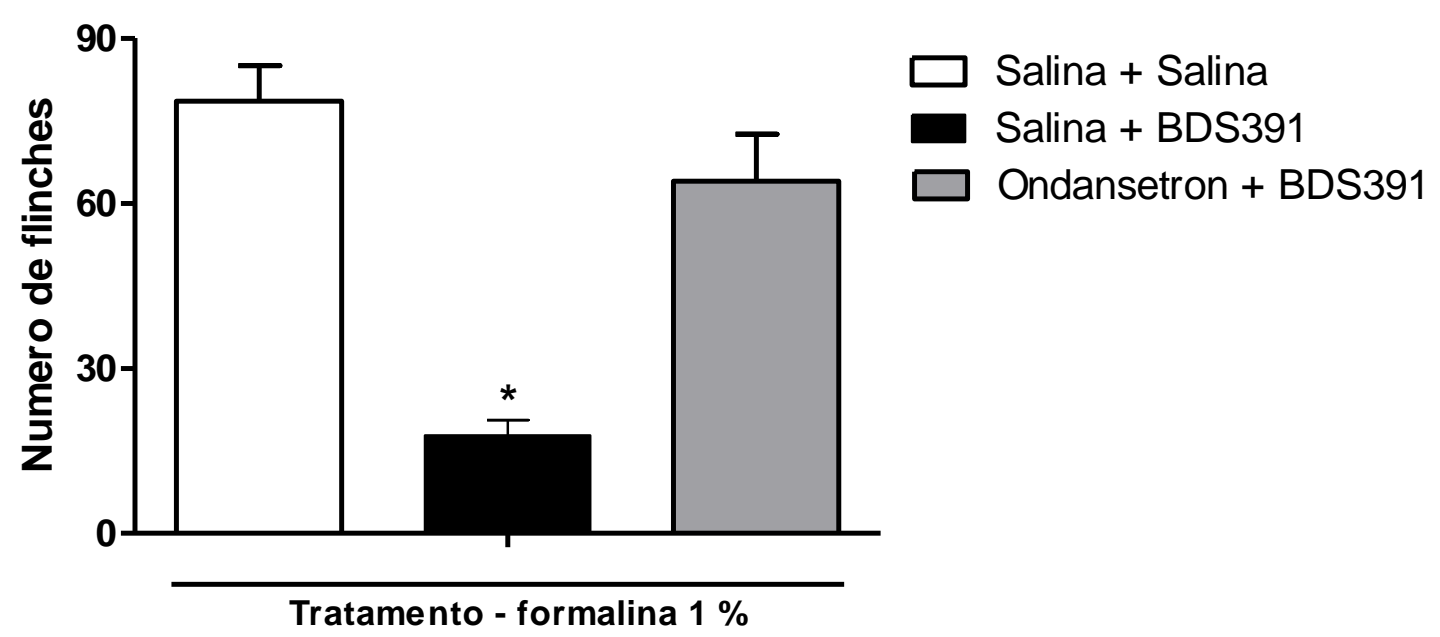

Figura 16: Participação do receptor $5-\mathrm{HT}_{3}$ no efeito antinociceptivo do BDS 391 sobre a nocicepção manifesta induzida por formalina. A formalina $1 \%$ foi administrada 30 minutos após o BDS 391. A nocicepção induzida pela formalina foi avaliada pelo numero de flinches (resposta) dos animais. A injeção de formalina induz duas fases distintas de nocicepção. Fase I (A), nocicepção neurogênica, observada até os 10 minutos iniciais. A Fase II (B), nocicepção inflamatória, é observada entre o período de $20-40$ minutos. O BDS 391, na dose de 1,5 $\mu \mathrm{M}$ foi administrado por via i.pl. $30 \mathrm{~min}$. antes da formalina. $\mathrm{O}$ Ondansetron (6 mM) foi administrado por via i.pl. $15 \mathrm{~min}$. antes do BDS 391. Como controle foram utilizados animais tratados com salina, nas mesmas condições experimentais. ${ }^{*} \mathrm{p}<0,05$ por comparação com o grupo salina. $\mathrm{N}=4$.

\subsection{Avaliação da ação da Biguanida, agonista de receptores $5-H_{3}$ sobre a nocicepção induzida por formalina.}

Uma vez que foi detectado envolvimento de receptores $5-\mathrm{HT}_{3}$ no efeito antinociceptivo do BDS 391, avaliamos presentemente, se o agonista seletivo deste receptor, a Biguanida, teria efeito antinociceptivo, utilizando o modelo de nocicepção induzida por formalina. Os resultados apresentados na Figura 17 indicam que este agonista inibiu parcialmente a nocicepção induzida pela formalina, interferindo com as duas fases desta resposta (Figuras 17A e 17B). Para avaliar se a dosa do Biguanida presentemente utilizada, induz apenas efeito local, este agonista na maior concentração, foi administrado na pata contralateral à pata injetada com formalina. Os resultados mostram que a Biguanida, na dose de $10 \mu \mathrm{M}$, injetada na pata contralateral, é capaz de inibir a nocicepção observada na fase 2 do teste de formalina, indicando que nesta concentração, o 
agonista induz efeito sistêmico (17B).
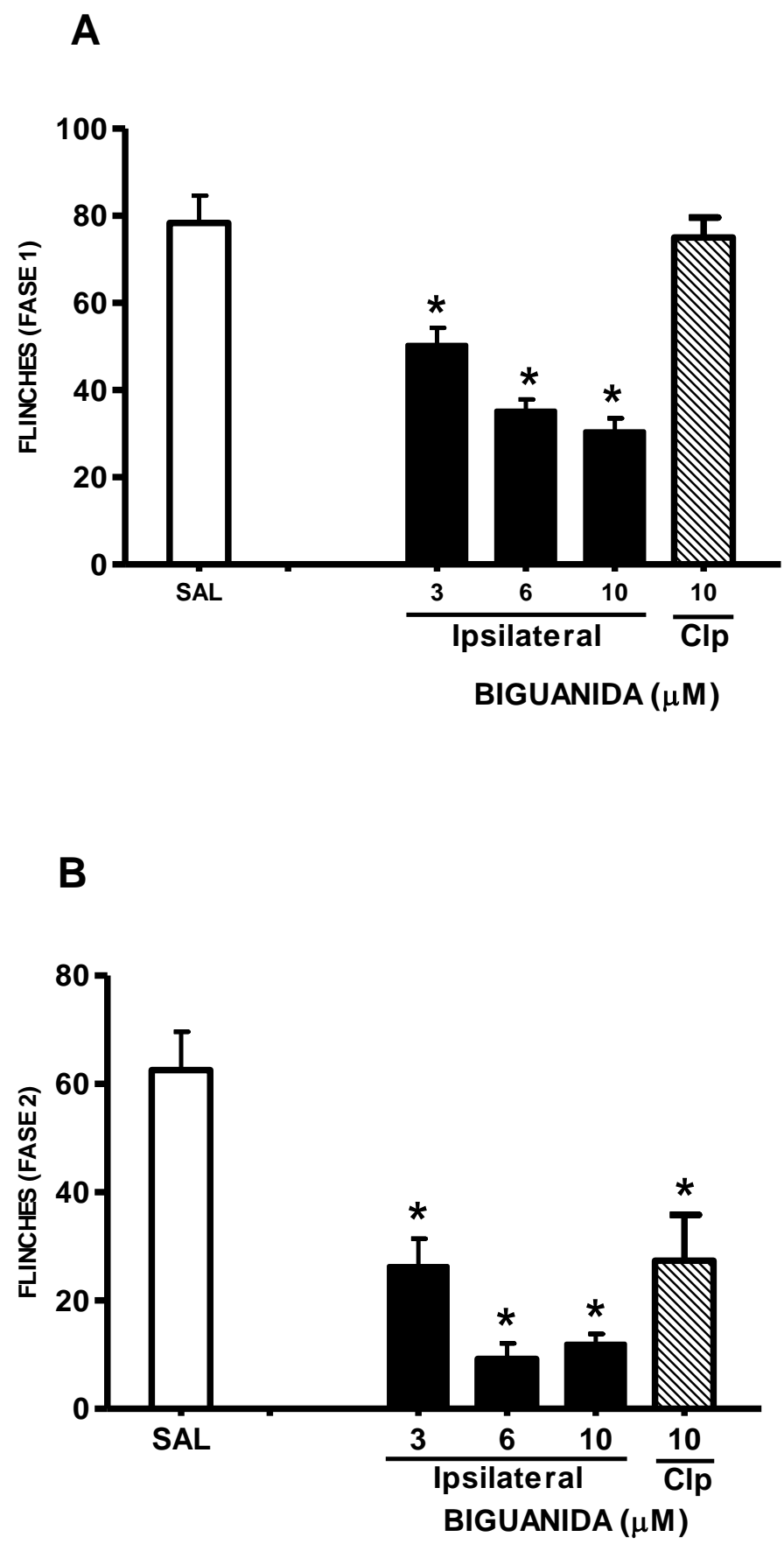

Figura 17: Ação da Biguanida sobre a nocicepção manifesta induzida por formalina. A nocicepção induzida por formalina foi avaliada pelo numero de flinches (resposta) dos animais. A injeção de formalina induz duas fases distintas de nocicepção. Fase 1 (A), nocicepção neurogênica, observada até os 10 minutos inicais. A Fase 2 (B), nocicepção inflamatória, é observada entre o período de 20 - 40 minutos. A Biguanida $(3,6$ e $10 \mu \mathrm{M})$ foi administrada por via i.pl. $30 \mathrm{~min}$. antes da formalina $1 \%$. Como controle foi utilizada salina, administrada via i.pl.. Ipsilateral - Pata tratada com formalina $1 \%$. Clp - Pata contralateral à pata tratada com formalina $1 \%$. ${ }^{*} \mathrm{p}<0,05$ por comparação com o grupo salina. $\mathrm{N}=4$. 


\subsection{Expressão de receptores 5-HT no nervo da pata e no gânglio da raiz dorsal (DRG)}

Dados de literatura têm evidenciado, por meio de estudos de expressão gênica, a presença, em tecidos periféricos, de receptores para serotonina dos subtipos 5- $\mathrm{HT}_{1}, 5-\mathrm{HT}_{2}$ e $5-\mathrm{HT}_{3}\left(\mathrm{Chen}_{\mathrm{T}}\right.$ et al., 1998; Pierce et al., 1996; Nicholson et al., 2003). No entanto, ainda não havia sido caracterizada a expressão protéica para estes receptores serotoninérgicos em nervo plantar e em células do gânglio da raiz dorsal (DRG). Desta forma, baseado nos dados, presentemente obtidos, mostrando que receptores serotoninérgicos periféricos estão envolvidos no efeito do BDS 391, avaliamos, por meio de ensaios de "immunoblotting" a presença destes receptores nesses tecidos. Os resultados obtidos, ainda preliminares, indicam que os subtipos 5-HT 1 e 5-HT 2 são expressos tanto no DRG quanto nas terminações nervosas periféricas obtidas de animais naive (Figura 18A e B). Os resultados sugerem que o subtipo 5- $\mathrm{HT}_{2}$ é expresso, em tecidos periféricos, em maior quantidade comparado ao subtipo 5- $\mathrm{HT}_{1 \mathrm{a}}$. Foi, também, observado que o receptor 5-HT 2 é expresso principalmente na forma glicosilada. (Figura 18B). Por outro lado, a expressão protéica de receptores $5-\mathrm{HT}_{3}$ foi detectada apenas nas terminações nervosas, mas não no DRG (Figura 18C).

A administração intraplantar de $\mathrm{PGE}_{2}$ não interferiu com a expressão de receptores serotoninérgicos tanto no nervo plantar ipsilateral à sua administração quanto no DRG, quando comparado com animais "naive” (NP) (Figura 18 A, B e C).

Os valores quantitativos da expressão protéica dos receptores serotoninérgicos avaliados foram apresentados, por valores arbitrários, mostrando a relação dos valores obtidos (pixels) entre a expressão do subtipo de receptor 5-HT e a expressão protéica da GAPDH. 
Results 74
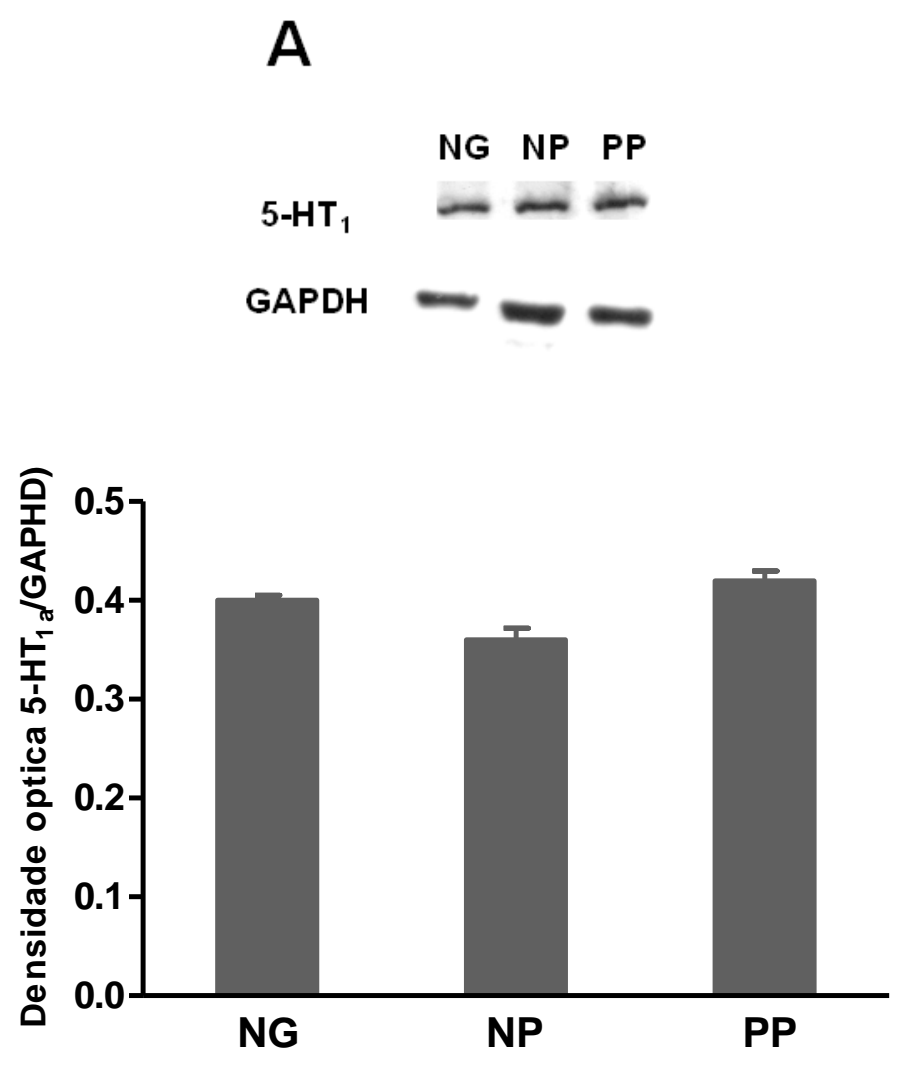
Results 75

B
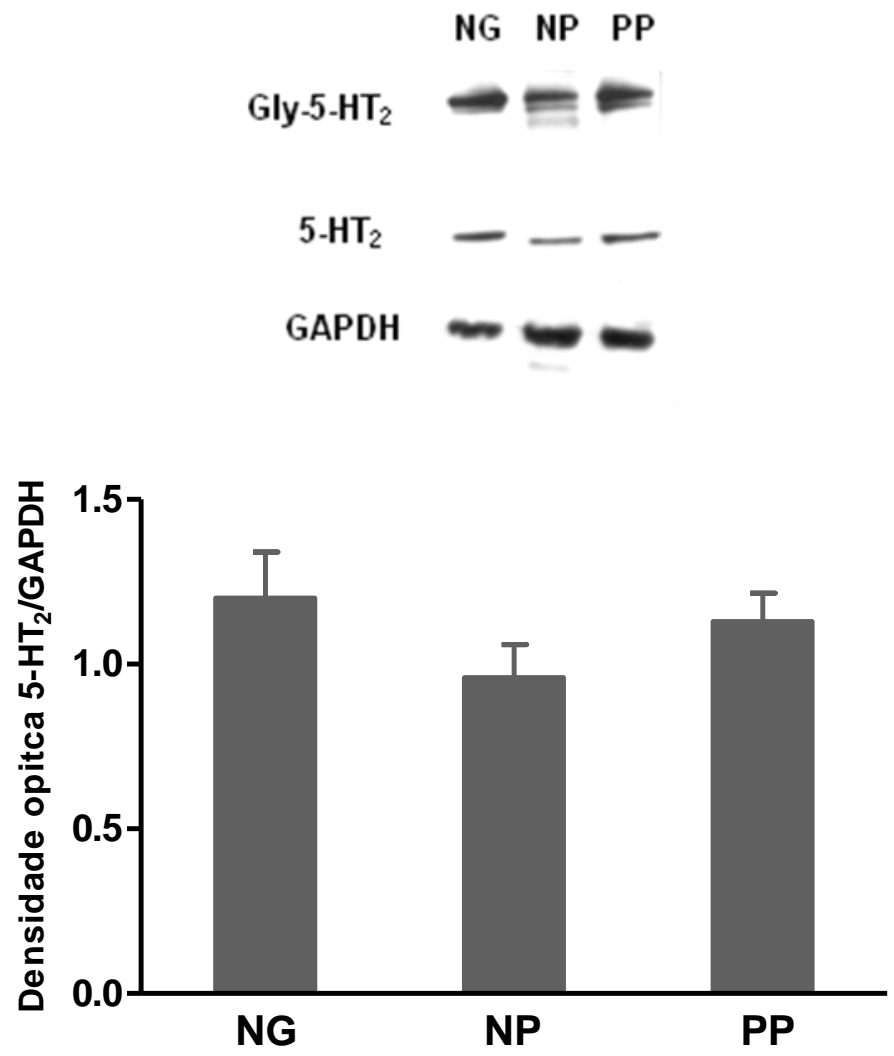

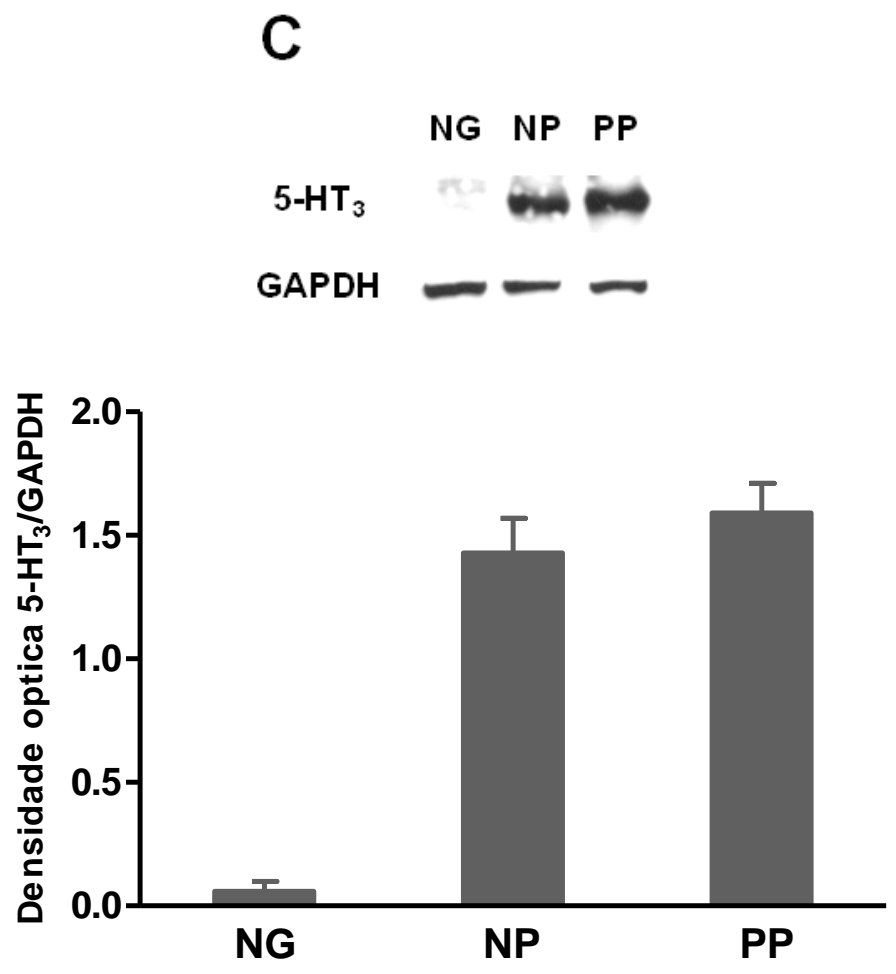

Figura 18: Expressão protéica de receptores serotoninérgicos $5-\mathrm{HT}_{1 \mathrm{a}}(\mathrm{A}), 5-\mathrm{HT}_{2}(\mathrm{~B})$ e $5-\mathrm{HT}_{3}(\mathrm{C})$. A expressão dos receptores foi avaliada por immunoblotting do lisado total do nervo da pata, na ausência (NP) ou vigência de sensibilização induzida por $\mathrm{PGE}_{2}(\mathrm{PP})$ e do gânglio da raiz dorsal, na ausência de sensibilização (NG). O lisado do nervo da pata do grupo PP foi obtido 180 min. após a administração de $\mathrm{PGE}_{2}$. Os valores estão normalizados pela expressão de GAPDH. Gly-5-HT 2 representa a expressão do receptor $5-\mathrm{HT}_{2}$ glicosilado. 


\subsection{Ensaio de ligação ("binding”) do BDS 391 a receptores serotoninérgicos}

Apesar dos resultados farmacológicos evidenciarem a participação de receptores do subtipo 5- $\mathrm{HT}_{3}$ no efeito antinociceptivo induzido pelo BDS 391, os resultados obtidos nos ensaios de ligação, mostraram que o BDS 391, na maior dose avaliada $(2 \mu \mathrm{M})$, não foi capaz de deslocar a ligação dos radioligantes $\left[{ }^{3} \mathrm{H}\right]$ 8-OH-DPAT $(1,5 \mathrm{nM}),\left[{ }^{3} \mathrm{H}\right]$ Kentanserin $(0,5 \mathrm{nM})$ e $\left[{ }^{3} \mathrm{H}\right]$ GR65630 (0,69 nM), respectivamente, antagonistas específicos de receptores 5- $\mathrm{HT}_{1 \mathrm{a}}, 5-\mathrm{HT}_{2}$ e 5$\mathrm{HT}_{3}$. Estes dados preliminares sugerem que o efeito do BDS 391 não é decorrente de uma ação direta sobre os receptores 5-HT.

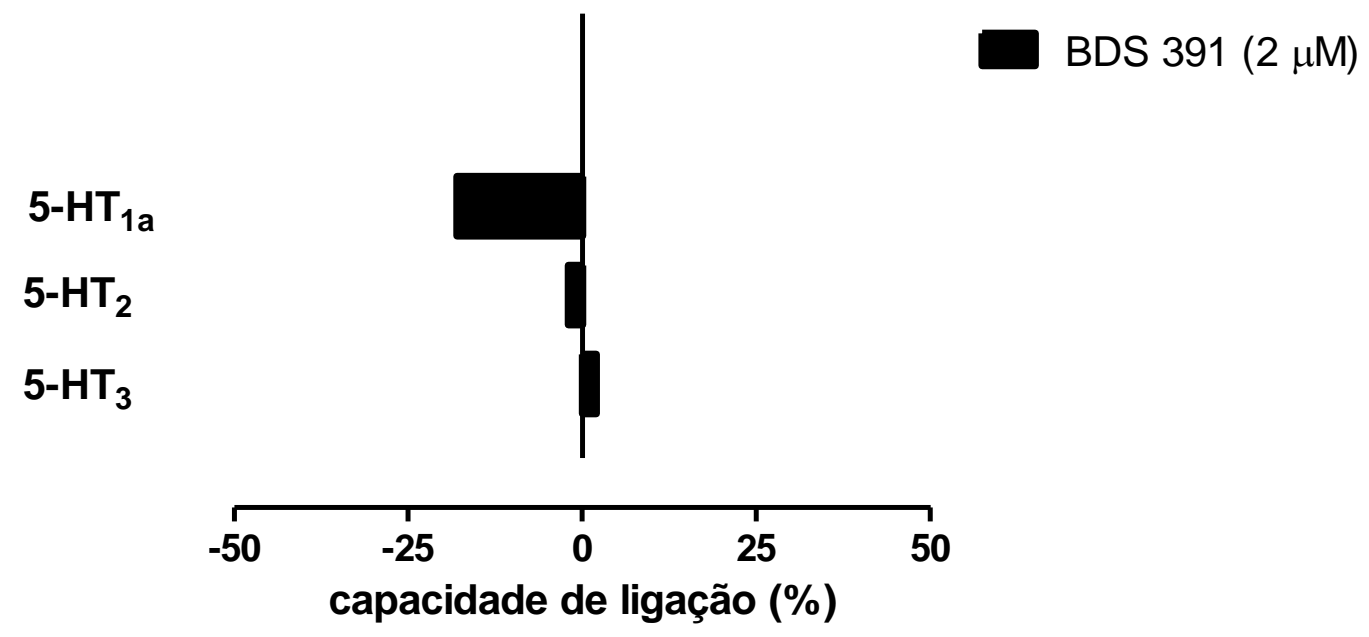

Figura 19: Avaliação da afinidade do BDS 391 por receptores 5-HT. O BDS $391(2 \mu \mathrm{M})$ não interferiu significativamente com a ligação do radioligantes. Respostas significativas são determinadas quando o composto é capaz de deslocar valores $\geq 50 \%$ dos radioligantes.

\subsection{Envolvimento de canais para Potássio dependentes de voltagem (Kv) no efeito antinociceptivo induzido pelo BDS 391}

Como mencionado na Introdução, dados preliminares sugerem a participação de canais para potássio dependentes de voltagem no efeito antinociceptivo induzido pelo BDS 391. Para ampliar a caracterização do mecanismo de ação antinociceptiva induzida pela molécula isolada da $B$. cangicum foi avaliada presentemente, por meio de ensaios eletrofisiológicos, a possível 
ação direta desta molécula sobre correntes iônicas em diferentes canais para potássio. Estes estudos foram desenvolvidos no Laboratório de Toxicologia do Departamento de Ciências Farmacêuticas da Universidade de Leuven - Bélgica, sob a orientação do Prof. Dr. Jan Tytgat, durante estágio realizado no período de 01 de Dezembro de 2009 a 06 de Janeiro de 2010. Os registros de correntes foram obtidos, pela técnica de "voltage clamp", em ovócitos de Xenopus laevis. Os dados eletrofisiológicos evidenciaram que o BDS 391 na concentração de $4 \mu \mathrm{M}$ não interferiu nas correntes iônicas dos canais Kv1.1 - 1.6, no canal Shaker de drosófila e no canal para potássio cardíaco humano (hERG). Estes dados estão apresentados na Figura 20.

Para confirmar os resultados obtidos nos ensaios farmacológicos, foi avaliada presentemente, a ação do Tetraetilamônio (TEA, 160, 320 e $640 \mu \mathrm{g}$, i.pl), bloqueador inespecífico para $\mathrm{Kv}$, no efeito antinociceptivo induzido pelo BDS 391, em modelo de hiperalgesia induzida por $\mathrm{PGE}_{2}$. O TEA foi administrado 30 minutos antes do BDS 391. Os resultados evidenciam que $3 \mathrm{~h}$ após a administração de $\mathrm{PGE}_{2}$ ocorreu diminuição do limiar nociceptivo dos animais (Figura 21), caracterizando o fenômeno de hiperalgesia. O BDS 391, na concentração de $150 \mathrm{nM}$, reverteu a hiperalgesi ainduzida pela $\mathrm{PGE}_{2}$. O TEA inibiu, de forma dose-dependente, o efeito antinociceptivo do BDS 391(Figura 2).

Estes resultados sugerem que o BDS 391 não é capaz de ativar diretamente os canais de potássio dependentes de voltagem. 
Kv1.1
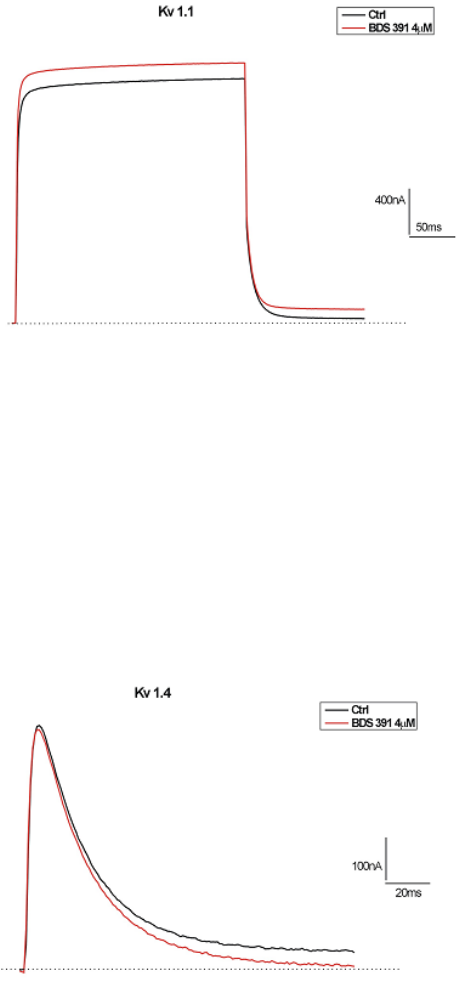

KN 12
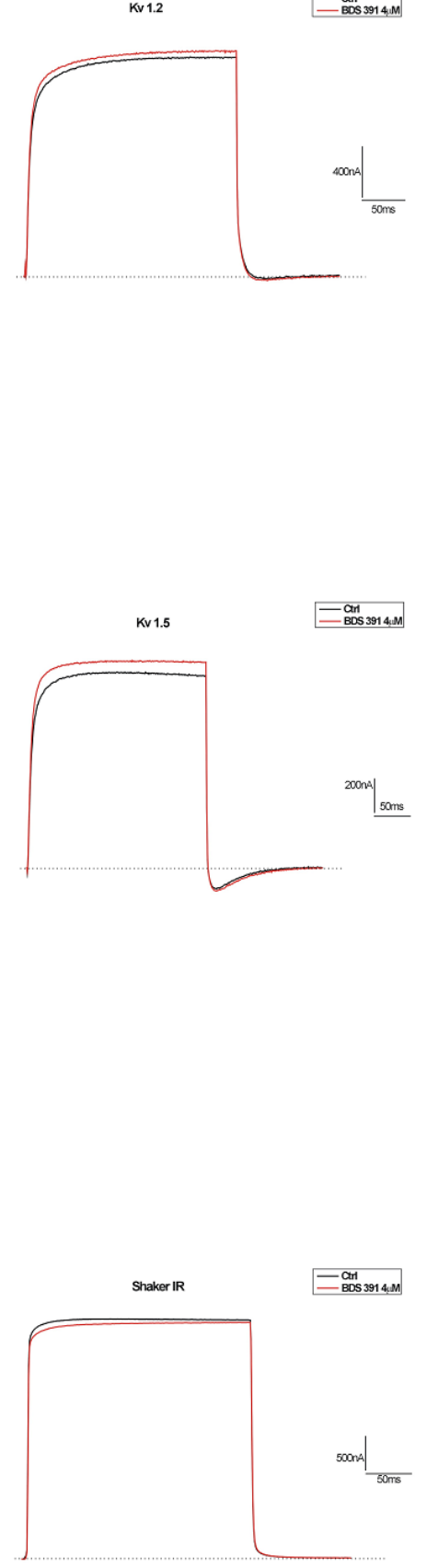

Resultados
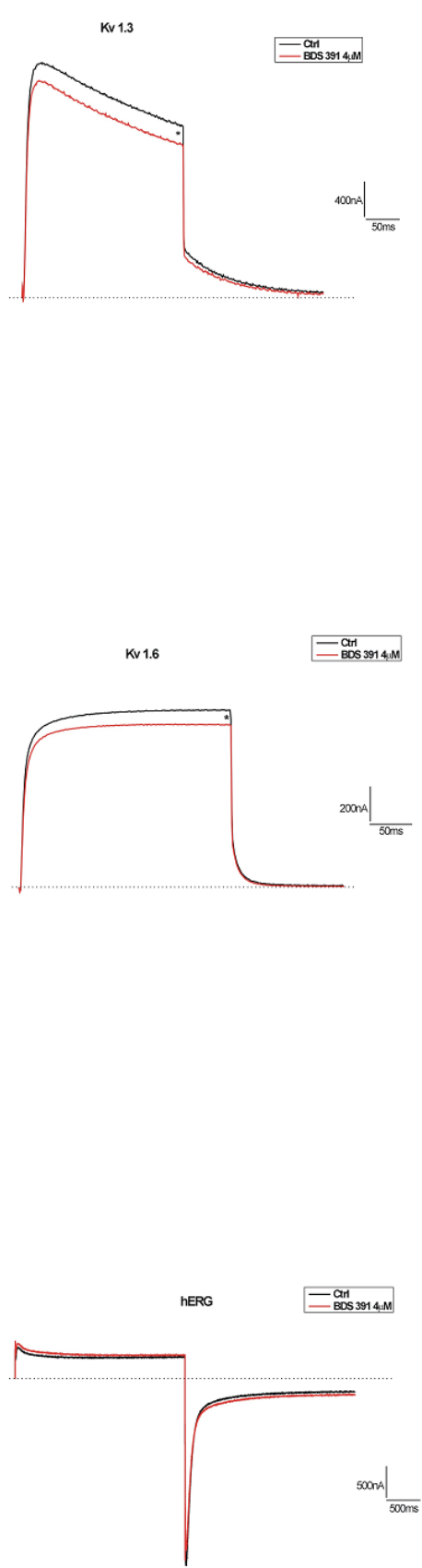

Figura 20: Registros eletrofisiológicos em ovócitos de Xenopus laevis. Os canais para potássio Kv1.1 - 1.6, ShaherIR e hERG, foram expressos em ovócitos de X. laevis por meio da inoculação de um vetor (pGEM-HE). Os registros de "voltage clamp" na configuração "whole cell” foram obtidos utilizando um amplificador Clamp 500, filtrado a $1 \mathrm{KHz}$, utilizando o software pCLAMP (Molecular Devices, Sunnyvale, CA, USA). Em preto estão representados as correntes iônicas em canais para Potássio antes da aplicação do composto BDS391 (controle). Em vermelho está representado as correntes iônicas registradas após a aplicação do BDS391 na solução banho. 


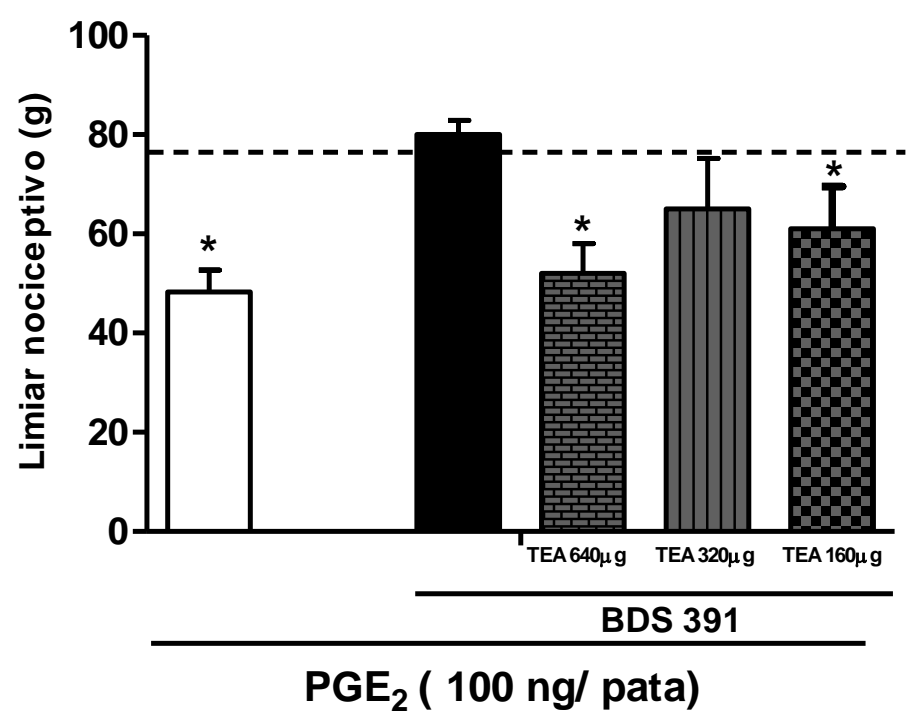

Figura 21: Participação de canais Kv no efeito antinociceptivo do BDS 391 em modelo de hiperalgesia induzida por $\mathrm{PGE}_{2}$. O TEA (640, 320 e $\left.160 \mu \mathrm{g} / \mathrm{pata}\right)$ foi administrado 30 minutos antes do BDS 391. Este ultimo, na dose $150 \mathrm{nM}$, foi administrado $150 \mathrm{~min}$ após a $\mathrm{PGE}_{2}$ (100ng/pata). Como controles, foram utilizados animais tratados com salina, nas mesmas condições experimentais. Para a avaliação do limiar nociceptivo foi utilizado o teste de pressão de patas. As medidas foram realizadas antes e $180 \mathrm{~min}$. após a $\mathrm{PGE}_{2}$. Os dados representam a média \pm e.p.m. dos animais por grupo* $\mathrm{p}<0,05$ por comparação com a medida inicial (linha tracejada).

\subsection{Efeito antinociceptivo do BDS 391 sintético e de seus análogos}

Neste estudo, foi também avaliado o efeito do BDS 391 sintético e de alguns análogos da molécula. Estes compostos foram obtidos em colaboração com o Prof. Dr. Katsuhiro Konno da Faculdade de Medicina Tropical da Universidade de Toyama. Foram desenvolvidos 3 novos compostos: 5-BrIAA-His, obtido pela alteração na posição do Br (Figura 22A), IAA-His, análogo sem a presença do $\mathrm{Br}$ na molécula (Figura 22B) e o 6BrIAA-OH, análogo que não possui a ligação peptídica com a histidina (Figura 22C). 


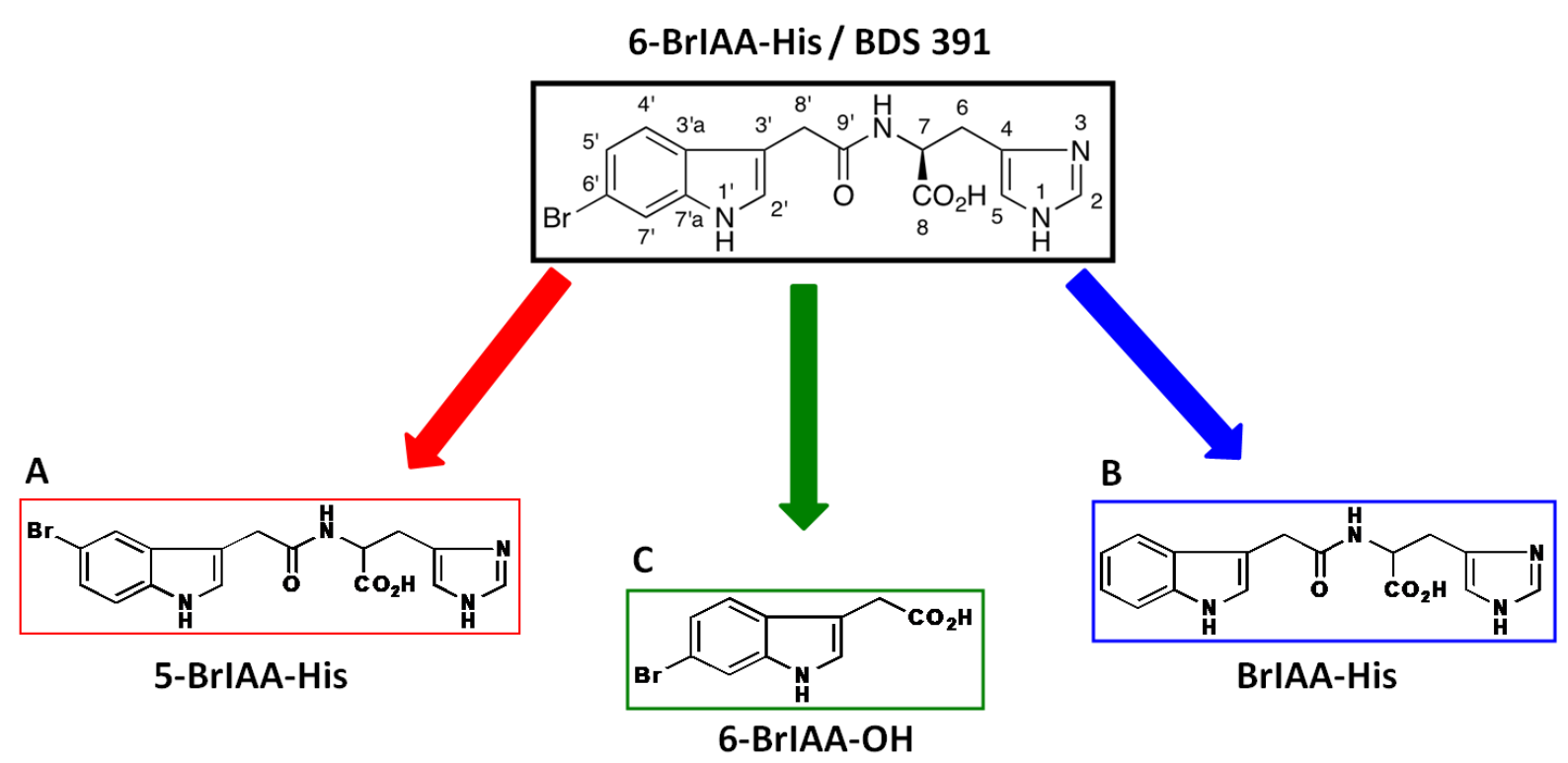

Figura 22: Síntese dos compostos BDS 391 e análogos. Os produtos sintéticos foram obtidos por um sintetizador de peptídeos automatizado MAPS-8 (Shimadzu Corporation, Kyoto, Japão), pelo método de fase sólida. (A) 5-BrIAA-His, (B) IAA-HIs e (C) 6-BrIAA-OH.

Para confirmar a atividade do composto BDS 391 sintético e investigar se a presença ou a posição do $\mathrm{Br}$ na estrutura molecular do BDS 391 é importante para o efeito antinociceptivo observado, avaliamos o efeito antinocieptivo do BDS 391 sintético e seus análogos no modelo de hiperalgesia induzida por $\mathrm{PGE}_{2}$. Os resultados mostram que a $\mathrm{PGE}_{2}$ acarretou hiperalgesia, representada pela diminuição do limiar nociceptivo, quando comparado com a medida basal (linha tracejada, Figura 23). O BDS 391 sintético e seus análogos, na dose de 150 nM, reverteram a hiperalgesia induzida por $\mathrm{PGE}_{2}$ (Figura 23). O BDS 391 sintético, mas não o seus análogos, foi capaz tanto de reverter a hiperalgesia quanto de acarretar aumento do limiar nociceptivo, em relação a medida basal, assim como observado nos testes com o BDS 391 obtido a partir da peçonha da anêmona $B$. cangicum. 


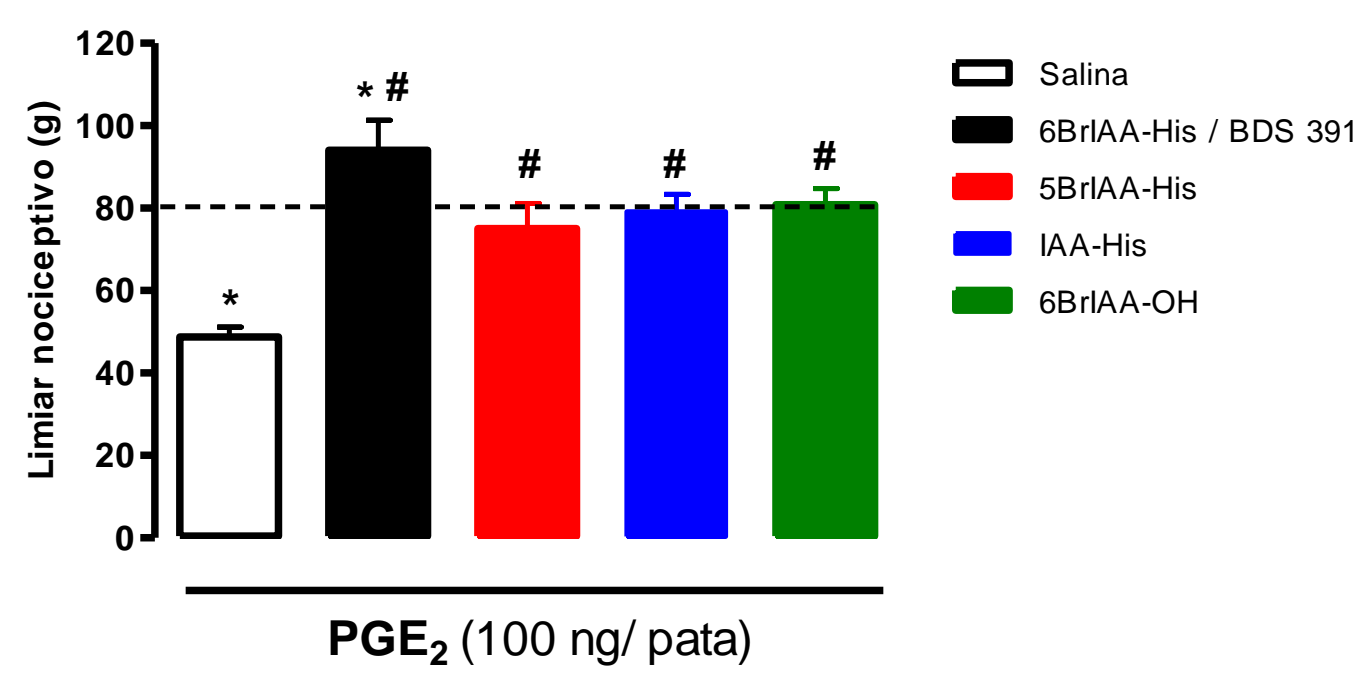

Figura 23: Efeito do BDS 391 sintético e seus análogos sobre a hiperalgesia induzida por prostaglandina $\mathrm{E}_{2}\left(\mathrm{PGE}_{2}\right)$. A sensibilidade dolorosa dos animais foi avaliada pelo teste de pressão da pata de ratos. Para a indução de hiperalgesia, os animais foram tratados com Prostaglandina $\mathrm{E}_{2}$ (100 ng/pata). O BDS 391 sintético e seus analogos, todos administrados na dose de $150 \mathrm{nM}$, foram administrados por via i.pl. 150 min. após a $\mathrm{PGE}_{2}$. Como controle foi utilizada salina. O teste de pressão de patas foi aplicado antes e 180 min. após a administração de $\mathrm{PGE}_{2}$. *p $<0,05$ por comparação com a medida antes do tratamento, \#p $<0,05$ por comparação com o grupo salina. $\mathrm{N}=5$. 


\section{DISCUSSÃO}

As anêmonas do mar utilizam suas potentes toxinas para paralisar presas e/ou para se defenderem de predadores. Dentre estas toxinas, destacam-se os peptídeos neurotóxicos (3000 a $6000 \mathrm{Da}$ ), que agem modulando canais iônicos (Diochot et al., 2003, 2004), e proteínas ( 20000 Da) com atividade hemolítica (Malpezzi e Freitas, 1991; Lagos et al., 2001; Anderluh e Macek, 2002; Oliveira et al., 2004). Além destas toxinas, alguns compostos de baixo peso molecular foram também isolados da peçonha de anêmonas do mar (Garateix et al., 1996; Freitas e Sawaya, 1990), contudo, a atividade biológica destes compostos ainda não é totalmente conhecida. Recentemente, foram isolados compostos bromados e de baixo peso molecular provenientes da peçonha de Bunodosoma cangicum, espécie encontrada no litoral Brasileiro. Estudos iniciais, realizados pelo nosso grupo, mostraram que um destes compostos, o BDS 391, é capaz de acarretar aumento no limiar nociceptivo basal de ratos e que este efeito é mediado pela ativação periférica de receptores serotoninérgicos e histaminérgicos e pela abertura de canais de potássio. Apesar destes dados, não havia sido avaliado ainda, o efeito deste composto em modelos de hipernocicepção aguda e crônica ou de nocicepção manifesta. Adicionalmente, não havia sido caracterizado o subtipo de receptor serotoninérgico e histaminérgico envolvido neste efeito. Assim, o objetivo geral deste projeto foi ampliar a caracterização do efeito antinociceptivo do BDS 391, utilizando diferentes modelos experimentais de avaliação de dor aguda e crônica, e dos mecanismos moleculares envolvidos nesta ação. No presente estudo, foi também elucidada a estrutura molecular do composto BDS 391 e avaliada a ação antinociceptiva de análogos sintéticos desta molécula.

Durante o processo de isolamento do BDS 391, a partir da peçonha da anêmona $B$. cangicum, foi obtida uma fração denominada "fração V" (FrV), da qual foram obtidos, após repurificação, vários compostos de massas moleculares variando entre 300 e 600 Da. Observando-se os compostos provenientes dessa fração, podemos ver que a diferença de 2 unidades de massa entre os íons detectados caracteriza a presença de compostos contendo 1

átomo de bromo, devido esse elemento químico ter os isótopos Br79 e Br81. Esse achado é extremamente interessante, pois demonstra a presença, na peçonha de anêmonas, de compostos 
halogenados de baixo peso molecular. Os estudos espectroscópicos apresentados nas Figuras 3, 4 e 5 mostram que se trata de um grupo bromoindol conectado a um aminoácido histidina. Os resultados indicam similaridade estrutural do núcleo indol do BDS 391 com a molécula de 5hidroxitriptamina (5-HT) (serotonina), exceto pela presença de um $\mathrm{Br}$ e pela conexão com uma histidina. Este grupamento indol também ocorre no hormônio vegetal ácido indolil- acético (AIA). O AIA é um hormônio detectado na urina humana, sendo um produto de degradação do aminoácido triptofano. Apesar destes dados, não é possível ainda afirmar que a molécula BDS 391 estaria presente na peçonha como fruto de degradação metabólica de aminoácidos ou se teria um papel efetivamente importante para a captura de presas, já que está presente nos cnidócitos e é injetado através dos nematocistos. Dados de literatura tem mostrado que moléculas de 5-HT, histamina e outras bioaminas estão presentes na peçonha de certas espécies de escorpiões e vespas (Adam e Weiss, 1959; Jaques e Schachter, 1954), mas esta é a primeira vez que se demosntra a presença de moléculas com estrura simile à serotonina, na peçonha de anemonas do mar.

Ainda, como o BDS 391 é uma nova substância, cujas atividades biológicas não são conhecidas, investigamos presentemente, a possível ação tóxica deste composto. Neste estudo foram utilizados siris azuis adultos (Callinectes danae). Apesar da espécie $C$. danae não ser uma presa natural da anêmona $B$. cangicum, esses animais foram utilizados, em substituição aos camundongos usualmente utilizados nos testes de toxicidade, uma vez que pertencem ao mesmo grupo animal (Filo Artrópodes) de presas reais da anêmona B. cangicum, alem disso os testes realizados em siris necessita de uma quantidade menor das toxinas para realização dos testes. Os resultados obtidos indicam ausência de atividade tóxica para o BDS 391, uma vez que o composto, ao contrario das neurotoxinas utilizadas como controle positivo, não apresentou nenhuma atividade letal ou paralisante, até a dose máxima utilizada ( $2 \mathrm{mg} / \mathrm{Kg}$, Tabela 2$)$.

Por apresentar, estruturalmente, um núcleo molecular serotonina-símile ligado a uma histidina, a possível ação do BDS 391 nas vias de transmissão da dor foi investigada. Como mencionado anteriormente, estudos iniciais realizados pelo nosso grupo, mostraram que o BDS 391 é capaz de induzir aumento no limiar nociceptivo de ratos, quando administrado por via intraplantar, em reposta a um estimulo nociceptivo mecânico (teste de pressão de patas) aplicado na ausência de sensibilização. Estes dados indicaram uma possível atividade antinociceptiva periférica para este composto. Assim, com o intuito de ampliar a caracterização desse efeito, 
avaliamos a ação do BDS 391 em outros modelos de nocicepção e hipernocicepção, como o modelo de hiperalgesia induzida pela $\mathrm{PGE}_{2}$, de dor neuropática induzida pela CCI e dor manifesta acarretada pela administração da formalina.

A hiperalgesia induzida pela prostaglandina é um modelo comumente empregado em estudos experimentais de dor. $\mathrm{A} \mathrm{PGE}_{2}$ não induz resposta inflamatória, mas age sensibilizando diretamente o neurônio sensitivo primário, pela interação com receptores acoplados a segundosmensageiros (Dray, 1995), causando diminuição do limiar de dor dos animais (Dray, 1995; Ferreira e Lorenzetti, 1981). Esta hiperalgesia é decorrente da ativação de receptores acoplados à proteína G estimulatória (Gs), resultando na estimulação da adenilato ciclase e aumento de AMPc intracelular (Ferreira e Nakamura, 1979; Taiwo e Levine, 1991). Este segundo mensageiro ativam as vias PKA dependente de AMPc (Cunha et al., 1999) e PKC dependente de fosfolipase C (Parada et al., 2005), resultando na despolarização da membrana celular e transmissão do impulso nociceptivo (Ferreira e Lorenzetti, 1994; Ito et al., 2001; Kassuya et al., 2007). Estudos eletrofisiológicos demonstram ainda, que a $\mathrm{PGE}_{2}$ aumenta a excitabilidade neuronal por suprimir as correntes de potássio (Evans et al., 1999) e/ou aumentando a atividade de canais de sódio resistentes à tetrodotoxina (England et al., 1996; Gold et al., 1996). Usualmente, a evidência de efeito analgésico periférico de um fármaco, sobre a hiperalgesia induzida pela $\mathrm{PGE}_{2}$, reflete ação direta deste fármaco sobre a atividade da fibra nervosa sensitiva aferente, responsável pela condução do impulso nociceptivo. Os resultados obtidos no presente estudo mostraram que o BDS 391 foi capaz de reverter o quadro hiperalgésico causado pela $\mathrm{PGE}_{2}$ e também, na maior dose, de aumentar o limiar nociceptivo dos animais quando comparado com a medida basal, indicando a efetividade analgésica deste composto neste modelo de sensibilização.

Além do modelo de sensibilização induzida por $\mathrm{PGE}_{2}$, avaliamos a efetividade do BDS 391 em modelo de dor crônica, mais especificamente, em um modelo de dor neuropática. A injúria de nervos periféricos em humanos resulta, muitas vezes, em dor neuropática crônica, caracterizada por dor espontânea em queimação, acompanhada de alodinia (dor em resposta a estímulos não lesivos) e hiperalgesia (dor exagerada em resposta a estímulos lesivos) (Dworkin et al., 2003; Payne e Norfleet, 1986). Este tipo de dor é usualmente de difícil controle, produzindo enorme repercussão na vida dos pacientes, de seus familiares e na sociedade como um todo (Caviedes e Herranz, 2002). 
No nosso estudo foi utilizado um modelo de dor neuropática induzida pela constrição crônica do nervo isquiático de ratos, de acordo com o método descrito por Bennett e Xie (1993, 1988). Neste método, a injúria parcial do nervo isquiático de rato ocorre como conseqüência à constrição do nervo, resultando em lesão parcial das fibras C. É importante ressaltar que no modelo presentemente utilizado, não foi observado o fenômeno de autotomia, usualmente detectado em modelos de ligaduras firmes do nervo isquiático, em que há destruição de todas as fibras nociceptivas (Seltzer et al., 1990). O modelo de dor neuropática acarretou aumento da sensibilidade dos animais tanto para estímulos nociceptivos (hiperalgesia), quanto para estímulos táteis (alodinia). Nossos dados mostraram que a administração via intraplantar, do BDS 391, no $14^{\circ}$ dia pós-operatório, inibiu a hiperalgesia e reverteu parcialmente a alodinia induzidas pela CCI, indicando a efetividade deste composto também em modelos de dor crônica. Esses dados são de grande importância, uma vez que, como mencionado anteriormente, os processos de dores crônicas são de difícil controle, sendo estas dores resistentes a diversas classes de analgésicos, incluindo fármacos opióides (Siegling et al., 2001, Fundytus et al., 2001, Collins et al., 2000).

No presente estudo foi também avaliado o efeito do BDS $391 \mathrm{em}$ um modelo de dor manifesta. Introduzido por Dubuisson e Dennis (1977), o modelo de dor manifesta induzida pela formalina é amplamente utilizado na caracterização de novas moléculas com ação analgésica, sendo considerado um modelo de dor inflamatória tônica (Tjolsen et al., 1992). A administração subcutânea, na pata de ratos, da formalina induz resposta comportamental estereotipada. Dentre os comportamentos, o movimento de levantar e abaixar a pata injetada ("flinche") foi presentemente utilizado como parâmetro da resposta nociceptiva. A reposta nociceptiva da formalina ocorre em duas fases distintas: a fase inicial (fase 1), caracterizada como nocicepção neurogênica, ocorre nos primeiros 10 minutos após a administração da formalina. Após um breve período, inicia-se a fase inflamatória (fase 2) que pode persistir por um período de até $1 \mathrm{~h}$ após a administração da formalina (Shibata et al., 1989; Wheeler-Aceto et al., 1990). A reposta inicial da formalina é atribuída ao efeito direto da formalina sobre os nociceptores (Hunskaar e Hole, 1987; Puig e Sorkin, 1996). Contudo, esta ativação direta das fibras sensoriais primárias pela formalina é questionada, uma vez que a bradicinina e antagonistas 5-HT são capazes de diminuir significativamente a resposta da fase 1 do teste de formalina (Doak e Sawynok, 1997; Corrêa e Calixto, 1993). Já a fase 2 desta resposta está relacionada à liberação local de mediadores endógenos responsáveis pela sensibilização dos neurônios sensitivos, sendo considerada uma fase 
inflamatória. Assim como o observado nos modelos de hiperalgesia induzida por PGE $_{2}$ e dor neuropática induzida por constrição do nervo ciático de ratos, o BDS 391 interferiu na nocicepção induzida pela formalina. Nas duas doses utilizadas (150 nM e 1,5 $\mu \mathrm{M})$, o composto BDS 391 reverteu parcialmente a fase neurogênica do teste de formalina e na maior concentração, inibiu a fase 2 da resposta a formalina (Figura 9).

Estes dados, em conjunto, indicam que o BDS 391 é capaz de induzir potente efeito antinociceptivo em diferentes modelos experimentais de dor. Este é o primeiro estudo que mostra atividade antinociceptiva para um composto de baixo peso molecular, não peptídico, obtido de uma anêmona do mar. Cabe ressaltar que, recentemente, foi descrito na literatura o efeito analgésico de um polipeptídio obtido a partir da peçonha da anêmona Heteractis crispa (Andreev et al., 2008). Este polipeptídio, de 56 resíduos de aminoácidos, denominado APHC1, é capaz de interagir com receptores TRPV1, bloqueando parcialmente as correntes iônicas induzidas por capsaicina.

Nesta fase do desenvolvimento do projeto, procedemos à caracterização dos mecanismos envolvidos no efeito antinociceptivo do BDS 391 nos modelos de hiperalgesia induzida por $\mathrm{PGE}_{2}$, dor neuropática (CCI) e dor manifesta induzida pela injeção de formalina. Como mencionado na Introdução, foi demonstrado anteriormente, pelo nosso grupo, o envolvimento de receptores para serotonina no aumento do limiar nociceptivo induzido pelo BDS 391 no teste de pressão de pata, na ausência de sensibilização. Os dados presentemente obtidos confirmam que receptores periféricos para serotonina estão envolvidos no efeito do BDS 391, contudo o subtipo de receptor serotoninérgico responsável pelo efeito deste composto depende do modelo experimental utilizado. Assim, os resultados obtidos indicam que os receptores 5 - $\mathrm{HT}_{1}$ não estão envolvidos no efeito do BDS 391, uma vez que a Spiroxatrina, antagonista do receptor 5-HT , $_{1}$ não interferiu na antinocicepção induzida pelo BDS 391, no modelo de hiperalgesia induzida por $\mathrm{PGE}_{2}$. Estes dados confirmam os resultados obtidos anteriormente, no teste de pressão de pata, na ausência de sensibilização, de que os receptores serotoninérgicos periféricos do subtipo 5-HT 1 não participam do aumento do limiar nociceptivo de ratos induzido pelo BDS 391 (Ferreira Jr e Cury, 2010 - manuscrito em elaboração). Curiosamente, o Ketanserim, antagonista seletivo para o receptor 5- $\mathrm{HT}_{2}$, reverteu parcialmente a antinocicepção do BDS 391 no modelo de hiperalgesia induzida por $\mathrm{PGE}_{2}$. Estes resultados diferem do observado anteriormente, em que não foi detectado o envolvimento do receptor 5- $\mathrm{HT}_{2}$ no efeito do composto BDS 391 no modelo de 
pressão de patas de ratos, na ausência de sensibilização periférica (Ferreira Jr e Cury, 2010 manuscrito em elaboração). Estes dados indicam que a presença de sensibilização periférica pode influenciar os mecanismos envolvidos no efeito antinociceptivo do BDS 391, bem como sugerir que perifericamente, a ativação de receptores $5-\mathrm{HT}_{2}$, na presença de sensibilização, pode acarretar efeito antinociceptivo. Os dados presentemente obtidos confirmam ainda que os receptores $5-\mathrm{HT}_{3}$ são os principais receptores envolvidos no efeito antinociceptivo do BDS 391, uma vez que o Ondansetron, antagonista destes receptores, inibiu o efeito analgésico induzido pelo BDS 391 no modelo de hiperalgesia induzida pela $\mathrm{PGE}_{2}$ (Figura 14C) e também no teste de pressão de patas de ratos na ausência de sensibilização periférica (Ferreira Jr e Cury, 2010 manuscrito em elaboração). É importante salientar que a ativação dos receptores 5- $\mathrm{HT}_{3}$ é influenciada por diversos fatores, não completamente identificados (Faerber et al., 2007). Os subtipos de receptores 5- $\mathrm{HT}_{3}$ e 5- $\mathrm{HT}_{2}$ são co-expressos nas fibras nociceptivas periféricas (Meller et al., 1991) e a interação entre estes subtipos de receptores tem sido observada. Assim, Hu e colaboradores (Hu et al., 2004) mostraram que a ativação do receptor 5-HT 3 pode ser potencializada pela ativação do receptor 5-HT2. Assim, nas nossas condições experimentais, a possível interação entre os receptores $5-\mathrm{HT}_{3}$ e $5-\mathrm{HT}_{2}$ deve ser considerada.

Uma vez caracterizada a participação do receptor 5- $\mathrm{HT}_{3}$ no efeito do BDS 391, na hiperalgesia induzida por $\mathrm{PGE}_{2}$, buscamos avaliar se o mesmo receptor estaria envolvido na antinocicepção induzida pela molécula BDS 391, nos modelos de dor manifesta e dor crônica. Os resultados apresentados nas Figuras 15 e 16, corroboram os dados mostrando que o receptor 5$\mathrm{HT}_{3}$ medeia o efeito antinociceptivo do BDS 391.

Para confirmar que a ativação de receptores $5-\mathrm{HT}_{3}$ periféricos induz antinocicepção, foi presentemente avaliada a ação da Biguanida, agonista seletivo para receptores $5-\mathrm{HT}_{3}$, no modelo de dor manifesta induzida por formalina. Nossos dados mostraram que a Biguanida inibe as duas fases do teste de formalina. Para avaliar se o agonista, nas doses utilizadas, apresenta apenas efeito local, foi realizado um experimento adicional, em que o agonista foi administrado na pata contralateral à pata injetada com formalina $1 \%$. Os resultados mostraram que, na maior dose, o agonista, administrado na pata contralateral, inibe a nocicepção induzida pela formalina, sugerindo que nesta dose, o efeito do agonista é sistêmico.

Os nossos resultados evidenciando que a ativação dos receptores 5 - $\mathrm{HT}_{3}$, nos tecidos 
periféricos, induz efeito antinociceptivo, são interessantes e importantes, uma vez que, de acordo com dados de literatura, o envolvimento destes receptores na transmissão do estimulo doloroso ainda é bastante controverso (Sommer, 2004, 2006). Os receptores $5-\mathrm{HT}_{3}$, localizados nas terminações nervosas pré-sinapticas, tem importante função no controle da liberação de neurotransmissores como glutamato, substancia P, dopaminas, GABA, acetilcolina e a própria serotonina (Greenshaw e Silverstorne, 1997; Funahashi et al., 2004). Por outro lado, a ativação dos receptores $5-\mathrm{HT}_{3}$ pós-sinapticos, induz rápida despolarização, que resulta do influxo de ions $\mathrm{Na}^{+}$e K ${ }^{+}$(Ronde e Nichols, 1998). Desta forma, os resultados presentemente obtidos corroboram com a hipótese de que o envolvimento dos receptores $5-\mathrm{HT}_{3}$ na via de sinalização dolorosa é condicionado a localização destes receptores, assim como ao modelo de nocicepção utilizado (Faerber et al., 2007).

É importante lembrar que, de acordo com os resultados de HR-MS/MS e NMR, o BDS 391 possui um núcleo estrutural similar a 5-HT (Figura 7). Uma analise comparativa dessa estrutura com os agonistas e antagonistas clássicos para o receptor 5- $\mathrm{HT}_{3}$ (Lochner e Lummis, 2010; Thompson e Lummis; 2006), evidencia a alta similaridade entre o BDS 391 e esses compostos, reforçando a idéia da possível interação do BDS 391 com o subtipo de receptor 5$\mathrm{HT}_{3}$. No entanto, os resultados dos ensaios de ligação ora obtidos sugerem que, apesar do efeito antinociceptivo ser mediado pela ativação de receptores 5-HT 3 , o BDS 391 não é capaz de ativar diretamente estes receptores, uma vez que este composto não interferiu, nos ensaios de "binding" com a ligação dos antagonistas radioligantes específicos para os receptores 5- $\mathrm{HT}_{1 \mathrm{a}}, 5-\mathrm{HT}_{2} \mathrm{e}$ 5-HT ${ }_{3}$. Contudo, deve-se ressaltar que esses resultados não excluem a possibilidade de interação do BDS 391 com outro sitio de ligação do receptor 5- $\mathrm{HT}_{3}$, distinto do sitio de ligação do antagonista seletivo deste receptor.

Conforme mencionado na Introdução, dados de literatura têm indicado a presença de receptores serotoninérgicos nos neurônios sensitivos, detectada por meio de analises da expressão gênica destes receptores (Chen et al., 1998, Nicholson et al., 2003). Contudo, não existem relatos da detecção da expressão protéica deste receptor nestes tecidos. Assim, em decorrência da deteç̧ão do envolvimento destes receptores no efeito periférico do BDS 391, confirmamos, presentemente, por meio da avaliação da expressão protéica (ensaios de immunobloting), a presença dos subtipos de receptores nestes neurônios. Os dados indicam que os receptores $5-\mathrm{HT}_{1 \mathrm{a}}$ 
e 5-HT 2 estão expressos tanto no nervo da pata quanto no DRG. A expressão protéica do receptor 5- $\mathrm{HT}_{3}$ foi detectada no tecido do nervo da pata, mas interessantemente, não foi detectada, nas nossas condições experimentais, no corpo celular de neurônios sensitivos (DRG). Cabe ressaltar que dados de literatura tem evidenciado a expressão do RNAm para este receptor no DRG (Morales et al., 2001). Até o momento, não temos dados que possam explicar a ausência de detecção da expressão deste receptor no DRG, mas deve-se considerar que a expressão protéica para o receptor $5-\mathrm{HT}_{3}$ pode estar ocorrendo em baixas quantidades ou que dependa de outros estímulos, dificultando a sua detecção pelos ensaios de immunoblotting, ou ainda, que os tempos utilizados no presente estudo, para a coleta do material, não tenham sido adequados para possibilitar esta detecção.

Vários dados de literatura têm indicado que, na presença de inflamação ou lesão tecidual, ocorre aumento da expressão gênica e protéica de receptores, como por exemplo, de receptores opióides (Hassan et al., 1993; Schafer et al., 1995; Ji et al., 1995). Dados recentes obtidos pelo nosso grupo, mostram que a prostaglandina $E_{2}$ é capaz não só de aumentar a expressão de receptores opióides, mas também de favorecer a maior ativação destes receptores pelo seu agonista (Zambelli e Cury, 2010 - manuscrito em elaboração) ${ }^{2}$. Assim, investigamos presentemente, se a sensibilização por prostaglandina acarretaria alteração na expressão de receptores serotoninérgicos, o que poderia favorecer a ativação destes receptores pelo BDS 391. Os resultados indicam que nas nossas condições experimentais, a $\mathrm{PGE}_{2}$ não é capaz de alterar a expressão protéica de nenhum dos sub-tipos de receptores serotoninérgicos avaliados.

No presente estudo avaliamos, também, o envolvimento de receptores para histamina na ação do BDS 391. Experimentos iniciais, utilizando o teste de pressão de patas, na ausência de sensibilização, indicaram que os receptores histaminérgicos estavam envolvidos no aumento do limiar nociceptivo induzido pelo BDS 391. Os dados obtidos indicam que, na presença de sensibilização, ao contrário do observado anteriormente, os receptores histaminérgicos não estão envolvidos no efeito antinociceptivo do BDS 391, uma vez que a Pirilamina, SKF e Tioperamida, antagonistas seletivos, respectivamente, para $\mathrm{H}_{1}, \mathrm{H}_{2}$ e $\mathrm{H}_{3}$, não interferiram com este efeito. As doses dos antagonistas utilizadas neste estudo estiveram baseadas em dados de literatura, uma vez que não foi possível a padronização destas doses, utilizando os respectivos agonistas, neste modelo de pressão de pata.

${ }^{2}$ Zambelli VO e Cury Y, Sao Paulo, 2010. 
Estudos iniciais sobre o efeito antinociceptivo do BDS 391, indicaram ainda, a participação de canais para potássio dependente de voltagem neste efeito. Para ampliar a caracterização deste mecanismo, realizamos ensaios farmacológicos, avaliando se, na presença de sensibilização por $\mathrm{PGE}_{2}$, os canais para potássio estariam também envolvidos no efeito antinociceptivo desta molécula. Para tanto, utilizamos o Tetraetilamônio (TEA), bloqueador inespecífico para Kv. Os resultados obtidos confirmaram o envolvimento destes canais, uma vez que o TEA foi capaz de reverter o efeito antinociceptivo induzido pelo BDS 391. Baseados nestes dados, foram realizados estudos eletrofisiológicos para avaliar a possível ação direta do BDS 391 sobre a atividade dos canais de potássio. Os resultados demonstram que o BDS 391 não foi capaz de interferir com as correntes iônicas dos canais de potássio dependentes de voltagem, canais estes expressos em ovócitos de Xenopus laevis. Desta forma, os resultados dos estudos farmacológicos indicando o envolvimento de canais para potássio dependentes de voltagem no efeito do BDS 391, indicam que esta ação pode ser indireta e decorrente da ativação do receptor serotoninérgico. Ronde e Nichols (1998) evidenciaram que a ativação de receptores 5-HT 3 induz despolarização do neurônio por influxo de correntes de $\mathrm{Na}^{+}$e $\mathrm{K}^{+}$. Adicionalmente, dados da literatura tem indicado que o TEA pode bloquear receptores 5-HT 3 (Kooyman et al., 1993), o que pode ter contribuído para os resultados ora obtidos.

Os dados apresentados até o momento indicam que o BDS 391, o qual é composto de um núcleo estrutural semelhante à serotonina, apresenta efeito analgésico periférico, em diferentes modelos de nocicepção. Este efeito é mediado pela ativação de receptores serotoninérgicos, sendo o subtipo 5- $\mathrm{HT}_{3}$ o principal receptor envolvido nesta ação. É importante ressaltar que grande parte dos estudos realizados na área de Toxinologia refere-se à caracterização bioquímica e farmacológica de moléculas protéicas e polipeptídios. Assim, a caracterização da atividade biológica do BDS 391, um composto não peptídico, se constitui em importante ferramenta em estudos na área de toxinas e também em estudos visando ampliar o conhecimento sobre os mecanismos moleculares envolvidos na dor e seu controle, além de fornecer a possibilidade da utilização desta molécula como modelo para o desenvolvimento de novos fármacos com atividade analgésica. 


\section{CONCLUSÃO}

Os resultados obtidos nesse estudo demonstram que:

* o BDS 391 induz efeito antinociceptivo, quando administrado via i.pl., nos modelos de nocicepção manifesta e hipernocicepção aguda e persistente;

* o efeito antinociceptivo induzido pelo BDS 391 é mediado pela ativação de receptores $5-\mathrm{HT}_{3}$ para serotonina periféricos.

* a ação do BDS 391 não é decorrente de interação direta do BDS 391 com o sitio de ligação do antagonista específico para 5- $\mathrm{HT}_{3}$;

* a ação analgésica induzida pelo BDS 391 envolve abertura de canais para potássio dependente de voltagem, no entanto o composto não interfere diretamente com a corrente iônica desses canais. 


\section{REFERÊNCIAS *}

Adam KR, Weiss C. Distribution of 5-hydroxytryptamine in scorpion venoms. Nature. 1959 May 16;183(4672):1398-9.

Aimone LD, Yaksh TL. Opioid modulation of capsaicin-evoked release of substance P from rat spinal cord in vivo. Peptides. 1989 Nov-Dec;10(6):1127-31.

Alves DP, Soares AC, Francischi JN, Castro MS, Perez AC, Duarte ID. Additive antinociceptive effect of the combination of diazoxide, an activator of ATP-sensitive $\mathrm{K}+$ channels, and sodium nitroprusside and dibutyryl-cGMP. Eur J Pharmacol. 2004 Apr 5;489(1-2):59-65.

Anderluh G, Macek P. Cytolytic peptide and protein toxins from sea anemones (Anthozoa: Actiniaria). Toxicon. 2002 Feb;40(2):111-24.

Andreev YA, Kozlov SA, Koshelev SG, Ivanova EA, Monastyrnaya MM, Kozlovskaya EP, Grishin EV. Analgesic compound from sea anemone Heteractis crispa is the first polypeptide inhibitor of vanilloid receptor 1 (TRPV1). J Biol Chem. 2008 Aug 29;283(35):23914-21.

Araque A, Urbano FJ, Cervenansky C, Gandia L, Buno W. Selective block of Ca(2+)-dependent $\mathrm{K}+$ current in crayfish neuromuscular system and chromaffin cells by sea anemone Bunodosoma cangicum venom. J Neurosci Res. 1995 Nov 1;42(4):539-46.

Arrang JM, Garbarg M, Schwartz JC. Auto-inhibition of brain histamine release mediated by a novel class (H3) of histamine receptor. Nature. 1983 Apr 28;302(5911):832-7.

Bardin L, Bardin M, Lavarenne J, Eschalier A. Effect of intrathecal serotonin on nociception in rats: influence of the pain test used. Exp Brain Res. 1997 Jan;113(1):81-7.

Bardin L, Schmidt J, Alloui A, Eschalier A. Effect of intrathecal administration of serotonin in chronic pain models in rats. Eur J Pharmacol. 2000 Dec 1;409(1):37-43.

Barke KE, Hough LB. Characterization of basal and morphine-induced histamine release in the rat periaqueductal gray. J Neurochem. 1994 Jul;63(1):238-44.

*De acordo com ASSOCIAÇÃO BRASILEIRA DE NORMAS TÉCNICAS. NBR 6023: Informação e documentação: referências: elaboração. Rio de Janeiro, 2002. 
Basbaum AI, Bautista DM, Scherrer G, Julius D. Cellular and molecular mechanisms of pain. Cell. 2009 Oct 16;139(2):267-84.

Beeton C, Barbaria J, Giraud P, Devaux J, Benoliel AM, Gola M, Sabatier JM, Bernard D, Crest $\mathrm{M}$, Beraud E. Selective blocking of voltage-gated $\mathrm{K}+$ channels improves experimental autoimmune encephalomyelitis and inhibits $\mathrm{T}$ cell activation. J Immunol. 2001 Jan 15;166(2):936-44.

Beeton C, Wulff H, Barbaria J, Clot-Faybesse O, Pennington M, Bernard D, Cahalan MD, Chandy KG, Beraud E. Selective blockade of $\mathrm{T}$ lymphocyte $\mathrm{K}(+)$ channels ameliorates experimental autoimmune encephalomyelitis, a model for multiple sclerosis. Proc Natl Acad Sci U S A. 2001 Nov 20;98(24):13942-7.

Beeton C, Chandy KG. Potassium channels, memory $\mathrm{T}$ cells, and multiple sclerosis. Neuroscientist. 2005 Dec;11(6):550-62.

Belmonte C, Cervero E. Neurobioloy of receptors. Oxford University Press: Oxford New York Tokyo; 1996.

Bennett GJ, Xie YK. Extraterritorial pain in rats with a peripheral mononeuropathy: mechanohyperalgesia and mechano-allodynia in the territory of an uninjured nerve. Pain. 1988; 50: 35563.

Bennett GJ, Xie YK. A peripheral mononeuropathy in rat that produces disorders of pain sensation like those seen in man. Pain. 1988 Apr;33(1):87-107.

Bennett G. An animal model of neuropathic pain: a review. Muscle \& Nerve. 1993;16:1040-8.

Beress L, Beress R, Wunderer G. Isolation and characterisation of three polypeptides with neurotoxic activity from Anemonia sulcata. FEBS Lett. 1975 Feb 15;50(3):311-4.

Besson JM. The neurobiology of pain. Lancet. 1999 May 8;353(9164):1610-5.

Bevan S. Nociceptive peripheral neurons: cellular properties. In: Wall PD, Melzack R, editors. Text Book of Pain. Edinburgh: Chuchill-Livingstone; 1999. p. 85-103. 
Bradford MM. A rapid and sensitive method for the quantitation of microgram quantities of protein utilizing the principle of protein-dye binding. Anal Biochem. 1976 May 7;72:248-54.

Brown RE, Stevens DR, Haas HL. The physiology of brain histamine. Prog Neurobiol. 2001 Apr;63(6):637-72.

Cannon KE, Hough LB. Inhibition of chemical and low-intensity mechanical nociception by activation of histamine H3 receptors. J Pain. 2005 Mar;6(3):193-200.

Cannon KE, Leurs R, Hough LB. Activation of peripheral and spinal histamine H3 receptors inhibits formalin-induced inflammation and nociception, respectively. Pharmacol Biochem Behav. 2007 Nov;88(1):122-9.

Caviedes BE, Herranz JL. Advances in physiopathology and the treatment of neuropathic pain. Rev Neurol. 2002 Dec 1-15;35(11):1037-48.

Chaplan SR, Bach FW, Pogrel JW, Chung JM, Yaksh TL. Quantitative assessment of tactile allodynia in the rat paw. Journal or Neuroscience Methods. 1994;53:55-63.

Chen JJ, Vasko MR, Wu X, Staeva TP, Baez M, Zgombick JM, Nelson DL. Multiple subtypes of serotonin receptors are expressed in rat sensory neurons in culture. J Pharmacol Exp Ther. 1998 Dec;287(3):1119-27.

Collins SL, Moore RA, McQuayHj, Wiffen P. Antidepressants and anticonvulsants for diabetic neuropathy and postherpetic neuralgia: a quantitative systematic review. J Pain Symptom Manage. 2000 Dec;20(6):449-58.

Corrêa CR, Calixto JB. Evidence for participation of B1 and B2 kinin receptors in formalininduced noceceptive response in the mouse. Br J Pharmacology. 1993;110:193-98.

Costigan M, Woolf CJ. Pain: molecular mechanisms. J Pain. 2000 Sep;1(3 Suppl):35-44.

Cousins MJC, M.L. Physisology and Psychology of Acute Pain. Acute Pain Management: Scientific Evidence. 2005:1-19. 
Cunha FQ, Teixeira MM, Ferreira SH. Pharmacological modulation of secondary mediator systems--cyclic AMP and cyclic GMP--on inflammatory hyperalgesia. Br J Pharmacol. 1999 Jun;127(3):671-8.

Cunha RB, Santana AN, Amaral PC, Carvalho MD, Carvalho DM, Cavalheiro EA, Maigret B, Ricart CA, Cardi BA, Sousa MV, Carvalho KM. Primary structure, behavioral and electroencephalographic effects of an epileptogenic peptide from the sea anemone Bunodosoma cangicum. Toxicon. 2005 Feb;45(2):207-17.

Cury Y, Picolo G. Animal toxins as analgesics--an overview. Drug News Perspect. 2006 Sep;19(7):381-92.

Cury Y, Picolo G. Are animal toxins good models for analgesics?. In: Maria Elena de Lima, Adriano Monteiro de Castro Pimenta, Marie France Martin-Eauclaire, Russolina Benedeta Zingali e Hervé Rochat. (Org.). Animal Toxins: State of the Art Perspectives in Health And Biotechnology. 1 ed. Minas Gerais: Editora UFMG, 2009, v. 1, p. 661-678.

Cury Y, Picolo G. Venenos Animais, dor e analgesia. In: João Luiz Costa Cardoso; Francisco Oscar de Siqueira França; Fan Hui Wen; Ceila Maria Sant'Ana Málaque; Vidal Hadda Jr. (Org.). Animais Peçonhentos no Barsil. 2 ed. Sao Paulo: Sarvier, 2009, v. , p. 406-416.

Dai Y, Iwata K, Fukuoka T, Kondo E, Tokunaga A, Yamanaka H, Tachibana T, Liu Y, Noguchi K. Phosphorylation of extracellular signal-regulated kinase in primary afferent neurons by noxious stimuli and its involvement in peripheral sensitization. J Neurosci. 2002 Sep 1;22(17):7737-45.

Daulhac L, Mallet C, Courteix C, Etienne M, Duroux E, Privat AM, Eschalier A, Fialip J. Diabetes-induced mechanical hyperalgesia involves spinal mitogen-activated protein kinase activation in neurons and microglia via N-methyl-D-aspartate-dependent mechanisms. Mol Pharmacol. 2006 Oct;70(4):1246-54.

Dina OA, McCarter GC, de Coupade C, Levine JD. Role of the sensory neuron cytoskeleton in second messenger signaling for inflammatory pain. Neuron. 2003 Aug 14;39(4):613-24.

Diochot S, Loret E, Bruhn T, Beress L, Lazdunski M. APETx1, a new toxin from the sea anemone Anthopleura elegantissima, blocks voltage-gated human ether-a-go-go-related gene potassium channels. Mol Pharmacol. 2003 Jul;64(1):59-69.

Diochot S, Baron A, Rash LD, Deval E, Escoubas P, Scarzello S, Salinas M, Lazdunski M. A new sea anemone peptide, APETx2, inhibits ASIC3, a major acid-sensitive channel in sensory 
neurons. Embo J. 2004 Apr 7;23(7):1516-25.

Doak GJ, Sawynok J. Formalin-induced nociceptive behavior and edema: involvement of multiple peripheral 5-hydroxytryptamine receptor subtypes. Neuroscience. 1997 Oct;80(3):93949.

Dray A. Inflammatory mediators of pain. Br J Anaesth. 1995;75:125-31.

Duarte ID, dos Santos IR, Lorenzetti BB, Ferreira SH. Analgesia by direct antagonism of nociceptor sensitization involves the arginine-nitric oxide-cGMP pathway. Eur J Pharmacol. 1992 Jul 7;217(2-3):225-7.

Dubuisson D, Dennis SG. The formalin test: a quantitative study of the analgesic effects of morphine, meperidine, and brain stem stimulation in rats and cats. Pain. 1977 Dec;4(2):161-74.

Dworkin RH, Backonja M, Rowbotham MC, Allen RR, Argoff CR, Bennett GJ, Bushnell MC, Farrar JT, Galer BS, Haythornthwaite JA, Hewitt DJ, Loeser JD, Max MB, Saltarelli M, Schmader KE, Stein C, Thompson D, Turk DC, Wallace MS, Watkins LR, Weinstein SM. Advances in neuropathic pain: diagnosis, mechanisms, and treatment recommendations. Arch Neurol. 2003 Nov;60(11):1524-34.

Eide PK, Hole K. The role of 5-hydroxytryptamine (5-HT) receptor subtypes and plasticity in the 5-HT systems in the regulation of nociceptive sensitivity. Cephalalgia. 1993 Apr;13(2):75-85.

England S, Bevan S, Docherty RJ. PGE2 modulates the tetrodotoxin-resistant sodium current in neonatal rat dorsal root ganglion neurones via the cyclic AMP-protein kinase A cascade. J Physiol. 1996 Sep 1;495 (Pt 2):429-40.

Evans AR, Vasko MR, Nicol GD. The cAMP transduction cascade mediates the PGE2-induced inhibition of potassium currents in rat sensory neurones. J Physiol. 1999 Apr 1;516 (Pt 1):163-78.

Faerber L, Drechsler S, Ladenburger S, Gschaidmeier H, Fischer W. The neuronal 5-HT3 receptor network after 20 years of research--evolving concepts in management of pain and inflammation. Eur J Pharmacol. 2007 Mar 29;560(1):1-8.

Farzin D, Asghari L, Nowrouzi M. Rodent antinociception following acute treatment with different histamine receptor agonists and antagonists. Pharmacol Biochem Behav. 2002 Jun;72(3):751-60. 
Ferreira SH. Prostaglandins, aspitin-like drugs and analgesia. Nature New Biol. 1972;240:200-3.

Ferreira SH, Moncada S, Vane JR. The blockade of the local generation of prostaglandins explains the analgesic action of aspirin. Agents Actions. 1973 Dec;3(5):385.

Ferreira SH, Nakamura MI. Prostaglandin hyperalgesia, a cAMP/Ca2+ dependent process. Prostaglandins. 1979 Aug;18(2):179-90.

Ferreira SH, Lorenzetti BB. Prostaglandin hyperalgesia, IV: a metabolic process. Prostaglandins. 1981 May;21(5):789-92.

Ferreira SH, Lorenzetti BB, Bristow AF, Poole S. Interleukin-1 beta as a potent hyperalgesic agent antagonized by a tripeptide analogue. Nature. 1988;334(6184):698-700.

Ferreira SH, Duarte ID, Lorenzetti BB. The molecular mechanism of action of peripheral morphine analgesia: stimulation of the cGMP system via nitric oxide release. Eur J Pharmacol. 1991 Aug 16;201(1):121-2.

Ferreira SH. Analgesia Con Oxido Nitrico Y Analgesicos. In: Berrazueta, J.R.. (Org.). Oxido nítrico endógeno y fármacos nitrovasodilatadores. Cantabria: Santander: Servicio de publicaciones de la Universidad de Cantabria, 1994, v. , p. 149-162.

Ferreira SH, Lorenzetti BB. Glutamate spinal retrograde sensitization of primary sensory neurons associated with nociception. Neuropharmacology. 1994 Nov;33(11):1479-85.

Ferreira SH, Lorenzetti BB. Glutamate spinal retrograde sensitization of primary sensory neurons associated with nociception. Neuropharmacology. 1995;33:1479.

Fozard JR. Neuronal 5-HT receptors in the periphery. Neuropharmacology. 1984 Dec;23(12B):1473-86.

Freitas JC, Sawaya MI. Increase of mammalian intestinal motility by the iminopurine caissarone isolated from the sea anemone Bunodosoma caissarum. Toxicon. 1990;28(9):1029-37. 
Funahashi M, Mitoh Y, Matsuo R. Activation of presynaptic 5-HT3 receptors facilitates glutamatergic synaptic input to area postrema neurons in rat brain slices. Methods Find. Exp. Clin. Pharmacol., 2004; 26, 615-622.

Fundytus ME, Yashpal K, Chabot JG, Osborne MG, Lefebvre CD, Dray A, Henry JL, Coderre TJ. Knockdown of spinal metabotropic glutamate receptor 1 (mGluR(1)) alleviates pain and restores opioid efficacy after nerve injury in rats. Br J Pharmacol. 2001 Jan;132(1):354-67.

Galeotti N, Ghelardini C, Vinci MC, Bartolini A. Role of potassium channels in the antinociception induced by agonists of alpha2-adrenoceptors. $\mathrm{Br} \quad \mathrm{J}$ Pharmacol. 1999 Mar;126(5):1214-20.

Galeotti N, Malmberg-Aiello P, Bartolini A, Schunack W, Ghelardini C. H1-receptor stimulation induces hyperalgesia through activation of the phospholipase C-PKC pathway. Neuropharmacology. 2004 Aug;47(2):295-303.

Garateix A, Flores A, Garcia-Andrade JM, Palmero A, Aneiros A, Vega R, Soto E. Antagonism of glutamate receptors by a chromatographic fraction from the exudate of the sea anemone Phyllactis flosculifera. Toxicon. 1996 Apr;34(4):443-50.

Ghanshani S, Wulff H, Miller MJ, Rohm H, Neben A, Gutman GA, Cahalan MD, Chandy KG. Up-regulation of the IKCa1 potassium channel during T-cell activation. Molecular mechanism and functional consequences. J Biol Chem. 2000 Nov 24;275(47):37137-49.

Giordano J, Rogers LV. Peripherally administered serotonin 5-HT3 receptor antagonists reduce inflammatory pain in rats. Eur J Pharmacol. 1989 Oct 24;170(1-2):83-6.

Giordano J, Gerstmann H. Patterns of serotonin- and 2-methylserotonin-induced pain may reflect 5-HT3 receptor sensitization. Eur J Pharmacol. 2004 Jan 12;483(2-3):267-9.

Gogas KR, Hough LB, Eberle NB, Lyon RA, Glick SD, Ward SJ, Young RC, Parsons ME. A role for histamine and H2-receptors in opioid antinociception. J Pharmacol Exp Ther. 1989 Aug;250(2):476-84.

Gold MS, Reichling DB, Shuster MJ, Levine JD. Hyperalgesic agents increase a tetrodotoxinresistant Na+ current in nociceptors. Proc Natl Acad Sci USA. 1996;93:1108-12. 
Greenshaw AJ, Silverstone PH. The non-antiemetic uses of serotonin 5-HT3 receptor antagonists. Drugs, 1997 53, 20-39.

Hassan AH, Ableitner A, Stein C, Herz A. Inflammation of the rat paw enhances axonal transport of opioid receptors in the sciatic nerve and increases their density in the inflamed tissue. Neuroscience. 1993 Jul;55(1):185-95.

Hong Y, Ohishi K, Inoue N, Kang JY, Shime H, Horiguchi Y, van der Goot FG, Sugimoto N, Kinoshita T. Requirement of N-glycan on GPI-anchored proteins for efficient binding of aerolysin but not Clostridium septicum alpha-toxin. Embo J. 2002 Oct 1;21(19):5047-56.

Honma T, Nagai H, Nagashima Y, Shiomi K. Molecular cloning of an epidermal growth factorlike toxin and two sodium channel toxins from the sea anemone Stichodactyla gigantea. Biochim Biophys Acta. 2003 Dec 1;1652(2):103-6.

Honma T, Hasegawa Y, Ishida M, Nagai H, Nagashima Y, Shiomi K. Isolation and molecular cloning of novel peptide toxins from the sea anemone Antheopsis maculata. Toxicon. 2005 Jan;45(1):33-41.

Honma T, Shiomi K. Peptide Toxins in Sea Anemones: Structural and Functional Aspects. Mar Biotechnol (NY). 2006 (8):1-10.

Honma T, Minagawa S, Nagai H, Ishida M, Nagashima Y, Shiomi K. Novel peptide toxins from acrorhagi, aggressive organs of the sea anemone Actinia equina. Toxicon. 2005 Dec 1;46(7):76874.

Hough LB, Jackowski S, Eberle N, Gogas KR, Camarota NA, Cue D. Actions of the brainpenetrating H2-antagonist zolantidine on histamine dynamics and metabolism in rat brain. Biochem Pharmacol. 1988 Dec 15;37(24):4707-11.

Hough LB, Nalwalk JW, Leurs R, Menge WM, Timmerman H. Antinociceptive activity of impentamine, a histamine congener, after CNS administration. Life Sci. 1999;64(5):PL79-86.

Hovius R, Tairi AP, Blasey H, Bernard A, Lundstrom K, Vogel H. Characterization of a mouse serotonin 5-HT3 receptor purified from mammalian cells. J Neurochem. 1998 Feb;70(2):824-34. 
Hu WP, Guan BC, Ru LQ, Chen JG, Li ZW. Potentiation of 5-HT3 receptor function by the activation of coexistent 5-HT2 receptors in trigeminal ganglion neurons of rats. Neuropharmacology. 2004 Nov;47(6):833-40.

Hunskaar S, Hole K. The formalin test in mice: dissociation between inflammatory and noninflammatory pain. Pain. 1987 Jul;30(1):103-14.

Ito S, Okuda-Ashitaka E, Minami T. Central and peripheral roles of prostaglandins in pain and their interactions with novel neuropeptides nociceptin and nocistatin. Neurosci Res. 2001 Dec;41(4):299-332.

Jaques R, Schachter M. The presence of histamine, 5-hydroxytryptamine and a potent, slow contracting substance in wasp venom. Br J Pharmacol Chemother. 1954 Mar;9(1):53-8.

Ji RR, Zhang Q, Law PY, Low HH, Elde R, Hokfelt T. Expression of mu-, delta-, and kappaopioid receptor-like immunoreactivities in rat dorsal root ganglia after carrageenan-induced inflammation. J Neurosci. 1995 Dec;15(12):8156-66.

Ji RR, Woolf CJ. Neuronal plasticity and signal transduction in nociceptive neurons: implications for the initiation and maintenance of pathological pain. Neurobiol Dis. 2001 Feb;8(1):1-10.

Julius D, Basbaum AI. Molecular mechanisms of nociception. Nature. 2001 Sep 13;413(6852):203-10.

Kalman K, Pennington MW, Lanigan MD, Nguyen A, Rauer H, Mahnir V, Paschetto K, Kem WR, Grissmer S, Gutman GA, Christian EP, Cahalan MD, Norton RS, Chandy KG. ShK-Dap22, a potent Kv1.3-specific immunosuppressive polypeptide. J Biol Chem. 1998 Dec 4;273(49):32697-707.

Kassuya CA, Ferreira J, Claudino RF, Calixto JB. Intraplantar PGE2 causes nociceptive behaviour and mechanical allodynia: the role of prostanoid E receptors and protein kinases. $\mathrm{Br} \mathbf{J}$ Pharmacol. 2007 Mar;150(6):727-37.

Kesim M, Duman EN, Kadioglu M, Yaris E, Kalyoncu NI, Erciyes N. The different roles of 5HT(2) and 5-HT(3) receptors on antinociceptive effect of paroxetine in chemical stimuli in mice. J Pharmacol Sci. 2005 Jan;97(1):61-6. 
Khanna N, Malhotra RS, Mehta AK, Garg GR, Halder S, Sharma KK. Interaction of morphine and potassium channel openers on experimental models of pain in mice. Fundam Clin Pharmacol. 2010. In press.

Kidd BL, Urban LA. Mechanisms of inflammatory pain. Br J Anaesth. 2001 Jul;87(1):3-11.

Kooyman AR, Zwart R, Vijverberg HP. Tetraethylammonium ions block 5-HT3 receptormediated ion current at the agonist recognition site and prevent desensitization in cultured mouse neuroblastoma cells. Eur J Pharmacol. 1993 Aug 15;246(3):247-54.

Lagos P, Duran R, Cervenansky C, Freitas JC, Silveira R. Identification of hemolytic and neuroactive fractions in the venom of the sea anemone Bunodosoma cangicum. Braz $\mathrm{J}$ Med Biol Res. $2001 \mathrm{Jul} ; 34(7): 895-902$.

Lanio ME, Morera V, Alvarez C, Tejuca M, Gomez T, Pazos F, Besada V, Martinez D, Huerta V, Padron G, de los Angeles Chavez M. Purification and characterization of two hemolysins from Stichodactyla helianthus. Toxicon. 2001 Feb-Mar;39(2-3):187-94.

Lázaro-Ibáñez G, Torres-López J, Granados-Soto V. Participation of the nitric oxide-cyclic GMPATP-sensitive $\mathrm{K}+$ channel pathway in the antinociceptive action of ketorolac. Eur $\mathrm{J}$ Pharmacol. 2001;426:39-44.

Lin Q, Peng YB, Willis WD. Antinociception and inhibition from the periaqueductal gray are mediated in part by spinal 5-hydroxytryptamine(1A) receptors. J Pharmacol Exp Ther. 1996 Mar;276(3):958-67.

Liu MY, Su CF, Lin MT. The antinociceptive role of a bulbospinal serotonergic pathway in the rat brain. Pain. 1988 Apr;33(1):123-9.

Lochner M, Lummis SC. Agonists and antagonists bind to an A-A interface in the heteromeric 5HT3AB receptor. Biophys J. 2010 Apr 21;98(8):1494-502.

Loeser JD, Treede RD. The Kyoto protocol of IASP Basic Pain Terminology. Pain. 2008 Jul 31;137(3):473-7.

Lohmann AB, Welch SP. ATP-gated $\mathrm{K}(+)$ channel openers enhance opioid antinociception: indirect evidence for the release of endogenous opioid peptides. Eur J Pharmacol. 1999 Dec 3;385(2-3):119-27. 
Lorenzetti BB, Ferreira SH. Activation of the arginine-nitric oxide pathway in primary sensory neurons contributes to dipyrone-induced spinal and peripheral analgesia. Inflamm Res. 1996 Jun;45(6):308-11.

Malpezzi EL, Freitas JC. Hemolytic activity of the nematocyst venom from the sea anemone Bunodosoma caissarum. Braz J Med Biol Res. 1991;24(12):1245-9.

Malpezzi EL, de Freitas JC, Muramoto K, Kamiya H. Characterization of peptides in sea anemone venom collected by a novel procedure. Toxicon. 1993 Jul;31(7):853-64.

Malmberg AB, Yaksh TL. Voltage-sensitive calcium channels in spinal nociceptive processing: blockade of $\mathrm{N}$ - and P-type channels inhibits formalin-induced nociception. J Neurosci. 1994 Aug;14(8):4882-90.

Malmberg LP, Sorva R, Sovijarvi AR. Frequency distribution of breath sounds as an indicator of bronchoconstriction during histamine challenge test in asthmatic children. Pediatr Pulmonol. 1994 Sep;18(3):170-7.

Malmberg AB, Basbaum AI. Partial sciatic nerve injury in the mouse as a model of neuropathic pain: behavioral and neuroanatomical correlates. Pain. 1998;76:215-22.

Malmberg-Aiello P, Lamberti C, Ipponi A, Bartolini A, Schunack W. Evidence for hypernociception induction following histamine $\mathrm{H} 1$ receptor activation in rodents. Life Sci. 1998;63(6):463-76.

Meller ST, Lewis SJ, Brody MJ, Gebhart GF. The Peripheral Nociceptive Actions of Intravenously Administered 5-Ht in the Rat Requires Dual Activation of Both 5-Ht2 and 5-Ht3 Receptor Subtypes. Brain Research. 1991 Oct 4;561(1):61-8.

Millan MJ. The induction of pain: an integrative review. Prog Neurobiol. 1999 Jan;57(1):1-164.

Millan MJ. Descending control of pain. Prog Neurobiol. 2002 Apr;66(6):355-474. 
Milligan ED, Mehmert KK, Hinde JL, Harvey LO, Martin D, Tracey KJ, Maier SF, Watkins LR. Thermal hyperalgesia and mechanical allodynia produced by intrathecal administration of the human immunodeficiency virus-1 (HIV-1) envelope glycoprotein, gp120. Brain Res. 2000 Apr 7;861(1):105-16.

Mobarakeh JI, Sakurada S, Hayashi T, Orito T, Okuyama K, Sakurada T, Kuramasu A, Watanabe T, Watanabe T, Yanai K. Enhanced antinociception by intrathecally-administered morphine in histamine H1 receptor gene knockout mice. Neuropharmacology. 2002 Jun;42(8):1079-88.

Morales M, McCollum N, Kirkness EF. 5-HT(3)-receptor subunits A and B are co-expressed in neurons of the dorsal root ganglion. J Comp Neurol. 2001 Sep 17;438(2):163-72.

Moran Y, Gordon D, Gurevitz M. Sea anemone toxins affecting voltage-gated sodium channels-molecular and evolutionary features. Toxicon. 2009 Dec 15;54(8):1089-101.

Mueller JL, Quock RM. Contrasting influences of 5-hydroxytryptamine receptors in nitrous oxide antinociception in mice. Pharmacol Biochem Behav. 1992 Feb;41(2):429-32.

Ness TJ. Pharmacology of peripheral analgesia. Pain Pract. 2001 Sep;1(3):243-54.

Netti C, Sibilia V, Guidobono F, Villani P, Pecile A, Braga PC. Evidence for an inhibitory role of central histamine on carrageenin-induced hyperalgesia. Neuropharmacology. 1994 Feb;33(2):205-10.

Nicholson R, Small J, Dixon AK, Spanswick D, Lee K. Serotonin receptor mRNA expression in rat dorsal root ganglion neurons. Neurosci Lett. 2003 Feb 13;337(3):119-22.

Nicholson BD. Diagnosis and management of neuropathic pain: a balanced approach to treatment. J Am Acad Nurse Pract. 2003 Dec;15(12 Suppl):3-9.

Norton RS, Zwick J, Beress L. Natural-abundance 13C nuclear-magnetic-resonance study of toxin II from Anemonia sulcata. Eur J Biochem. 1980 Dec;113(1):75-83.

Norton RS. Structure and structure-function relationships of sea anemone proteins that interact with the sodium channel. Toxicon. 1991;29(9):1051-84. 
Obata K, Noguchi K. MAPK activation in nociceptive neurons and pain hypersensitivity. Life Sci. 2004 Apr 9;74(21):2643-53.

Ohkubo T, Shibata M, Inoue M, Kaya H, Takahashi H. Regulation of substance P release mediated via prejunctional histamine H3 receptors. Eur J Pharmacol. 1995 Jan 24;273(1-2):83-8.

Ohkubo T, Shibata M. ATP-sensitive K+ channels mediate regulation of substance P release via the prejunctional histamine $\mathrm{H} 3$ receptor. European journal of pharmacology. 1995 Apr $13 ; 277(1): 45-9$.

Oliveira JS, Redaelli E, Zaharenko AJ, Cassulini RR, Konno K, Pimenta DC, Freitas JC, Clare JJ, Wanke E. Binding specificity of sea anemone toxins to Nav 1.1-1.6 sodium channels: unexpected contributions from differences in the IV/S3-S4 outer loop. J Biol Chem. 2004 Aug 6;279(32):33323-35.

Oliveira JS, Zaharenko AJ, Ferreira WA, Jr., Konno K, Shida CS, Richardson M, Lucio AD, Beirao PS, de Freitas JC. BcIV, a new paralyzing peptide obtained from the venom of the sea anemone Bunodosoma caissarum. A comparison with the $\mathrm{Na}+$ channel toxin BcIII. Biochim Biophys Acta. 2006 Oct;1764(10):1592-600.

Ortiz MI, Torres-Lopez JE, Castaneda-Hernandez G, Rosas R, Vidal-Cantu GC, Granados-Soto V. Pharmacological evidence for the activation of $\mathrm{K}(+)$ channels by diclofenac. Eur $\mathrm{J}$ Pharmacol. 2002 Mar 1;438(1-2):85-91.

Pan HL, Wu ZZ, Zhou HY, Chen SR, Zhang HM, Li DP. Modulation of pain transmission by Gprotein-coupled receptors. Pharmacol Ther. 2008 Jan;117(1):141-61.

Panula P, Yang HY, Costa E. Histamine-containing neurons in the rat hypothalamus. Proc Natl Acad Sci U S A. 1984 Apr;81(8):2572-6.

Parada CA, Vivancos GG, Tambeli CH, de Queiroz Cunha F, Ferreira SH. Activation of presynaptic NMDA receptors coupled to NaV1.8-resistant sodium channel C-fibers causes retrograde mechanical nociceptor sensitization. Proc Natl Acad Sci U S A. 2003 Mar 4;100(5):2923-8.

Parada CA, Reichling DB, Levine JD. Chronic hyperalgesic priming in the rat involves a novel interaction between cAMP and PKCepsilon second messenger pathways. Pain. 2005 Jan;113(12):185-90. 
Passani MB, Bacciottini L, Mannaioni PF, Blandina P. Central histaminergic system and cognition. Neurosci Biobehav Rev. 2000 Jan;24(1):107-13.

Payne B, Norfleet MA. Chronic pain and the family: a review. Pain. 1986 Jul;26(1):1-22.

Peng YB, Lin Q, Willis WD. The role of 5-HT3 receptors in periaqueductal gray-induced inhibition of nociceptive dorsal horn neurons in rats. J Pharmacol Exp Ther. 1996 Jan;276(1):116-24.

Pierce PA, Xie GX, Levine JD, Peroutka SJ. 5-Hydroxytryptamine receptor subtype messenger RNAs in rat peripheral sensory and sympathetic ganglia: a polymerase chain reaction study. Neuroscience. 1996 Jan;70(2):553-9.

Pierce PA, Xie GX, Peroutka SJ, Levine JD. Dual effect of the serotonin agonist, sumatriptan, on peripheral neurogenic inflammation. Reg Anesth. 1996 May-Jun;21(3):219-25.

Poveda R, Fernandez-Duenas V, Fernandez A, Sanchez S, Puig MM, Planas E. Synergistic interaction between fentanyl and the histamine $\mathrm{H} 3$ receptor agonist R-(alpha)-methylhistamine, on the inhibition of nociception and plasma extravasation in mice. Eur J Pharmacol. $2006 \mathrm{Jul}$ 10;541(1-2):53-6.

Puig S, Sorkin LS. Formalin-evoked activity in identified primary afferent fibers: systemic lidocaine suppresses phase-2 activity. Pain. 1996 Feb;64(2):345-55.

Raffa RB. Antihistamines as analgesics. J Clin Pharm Ther. 2001 Apr;26(2):81-5.

Ramam M, Bhat R, Garg T, Sharma VK, Ray R, Singh MK, Banerjee U, Rajendran C. A modified two-step treatment for actinomycetoma. Indian J Dermatol Venereol Leprol. 2007 JulAug;73(4):235-9.

Randall LO, Selitto JJ. A method for measurement of analgesic activity on inflamed tissue. Arch Int Pharmacodyn Ther. 1957 Sep 1;111(4):409-19.

Rang HP, Dale MM, Ritter JM. Farmacologia. Rio de Janeiro: Guanabara Koogan; 1997. 
Ren K, Dubner R. Neuron-glia crosstalk gets serious: role in pain hypersensitivity. Curr Opin Anaesthesiol. 2008 Oct;21(5):570-9.

Reichling DB, Levine JD. The primary afferent nociceptor as pattern generator. Pain. 1999 Aug;Suppl 6:S103-9.

Rodrigues AR, Duarte ID. The peripheral antinociceptive effect induced by morphine is associated with ATP-sensitive K(+) channels. Br J Pharmacol. 2000 Jan;129(1):110-4.

Ronde P, Nichols RA. High calcium permeability of serotonin 5-HT3 receptors on presynaptic nerve terminals from rat striatum. J Neurochem. 1998 Mar;70(3):1094-103.

Sachs D, Cunha FQ, Ferreira SH. Peripheral analgesic blockade of hypernociception: activation of arginine/NO/cGMP/protein kinase G/ATP-sensitive K+ channel pathway. Proc Natl Acad Sci U S A. 2004 Mar 9;101(10):3680-5.

Saegusa H, Matsuda Y, Tanabe T. [Structure and function of T-type calcium channels]. Clin Calcium. 2002 Jun;12(6):792-6.

Sander K, Kottke T, Stark H. Histamine H3 receptor antagonists go to clinics. Biol Pharm Bull. 2008 Dec;31(12):2163-81.

Santos AR, De Campos RO, Miguel OG, Cechinel-Filho V, Yunes RA, Calixto JB. The involvement of $\mathrm{K}+$ channels and $\mathrm{Gi} / \mathrm{o}$ protein in the antinociceptive action of the gallic acid ethyl ester. Eur J Pharmacol. 1999 Aug 20;379(1):7-17.

Schaeffer RC, Jr., Randall H, Resk J, Carlson RW. Enzyme-linked immunosorbant assay (ELISA) of size-selected crotalid venom antigens by Wyeth's polyvalent antivenom. Toxicon. 1988;26(1):67-76.

Schafer M, Imai Y, Uhl GR, Stein C. Inflammation enhances peripheral mu-opioid receptormediated analgesia, but not mu-opioid receptor transcription in dorsal root ganglia. Eur $\mathbf{J}$ Pharmacol. 1995 Jun 12;279(2-3):165-9.

Schaible HG, Richter F. Pathophysiology of pain. Langenbecks Arch Surg. 2004 Aug;389(4):23743. 
Schemelz M, Schmidt R, Ringkamp M, Handwerker HO, Torebjork HE. Senstitizaion of intensive branches of C nociceptors in human skin. J Physiology. 1994;480:389-94.

Schreiter C, Hovius R, Costioli M, Pick H, Kellenberger S, Schild L, Vogel H. Characterization of the ligand-binding site of the serotonin 5-HT3 receptor: the role of glutamate residues 97, 224, AND 235. J Biol Chem. 2003 Jun 20;278(25):22709-16.

Seltzer Z, Dubner R, Shir Y. A novel behavioral model of neuropathic pain disorders produced in rats by partial sciatic nerve injury. Pain. 1990 Nov;43(2):205-18.

Shibata M, Ohkubo T, Takahashi H, Inoki R. Modified formalin test: characteristic biphasic pain response. Pain. 1989 Sep;38(3):347-52.

Siegling A, Hofmann HA, Denzer D, Mauler F, De Vry J. Cannabinoid CB(1) receptor upregulation in a rat model of chronic neuropathic pain. Eur J Pharmacol. 2001 Mar 9;415(1):R57.

Smith HS. Activated microglia in nociception. Pain Physician. 2010 May-Jun;13(3):295-304.

Snedecor GW, Sokal RR, Rohlf FJ. Statistical methods Biometry. In: Freeman WH, Co, editor. New York: Owa State University Press; 1946.

Sokal RR e Rohlf FJ. Biometry, W.H.F. Freeman and Co, editor. New York: 1981.

Sommer C. Serotonin in pain and analgesia: actions in the periphery. Mol Neurobiol. 2004. Oct;30(2):117-25.

Sommer C. Is serotonin hyperalgesic or analgesic? Curr Pain Headache Rep. 2006 Apr;10(2):101-6.

Suzuki T, Takamori K, Takahashi Y, Narita M, Misawa M, Onodera K. The differential effects of histamine receptor antagonists on morphine- and $\mathrm{U}-50,488 \mathrm{H}$-induced antinociception in the mouse. Life Sci. 1994;54(3):203-11.

Taiwo YO, Levine JD. Kappa- and delta-opioids block sympathetically dependent hyperalgesia. J Neurosci. 1991 Apr;11(4):928-32. 
Taiwo YO, Levine JD. Serotonin is a directly-acting hyperalgesic agent in the rat. Neuroscience. 1992;48(2):485-90.

Thompson AJ, Lummis SC. 5-HT3 receptors. Curr Pharm Des. 2006;12(28):3615-30.

Tjolsen A, Berge OG, Hunskaar S, Rosland JH, Hole K. The formalin test: an evaluation of the method. Pain. 1992 Oct;51(1):5-17.

Tokunaga Y, Hata K, Nishitai R, Kaganoi J, Nanbu H, Ohsumi K. Spontaneous perforation of the rectum with possible stercoral etiology: report of a case and review of the literature. Surg Today. 1998;28(9):937-9.

Turk T, Kem WR. The phylum Cnidaria and investigations of its toxins and venoms until 1990. Toxicon. 2009; 54(8):1031-7.

Wanke E, Zaharenko AJ, Redaelli E, Schiavon E. Actions of sea anemone type 1 neurotoxins on voltage-gated sodium channel isoforms. Toxicon. 2009 Dec 15;54(8):1102-11.

Wheeler-Aceto H, Porreca F, Cowan A. The rat paw formalin test: comparison of noxious agents. Pain. 1990 Feb;40(2):229-38.

Wieseler-Frank J, Maier SF, Watkins LR. Glial activation and pathological pain. Neurochem Int. 2004 Jul-Aug;45(2-3):389-95.

Woolf CJ. Pain. Neurobiol Dis. 2000 Oct;7(5):504-10.

Woolf CJ. Pain: moving from symptom control toward mechanism-specific pharmacologic management. Ann Intern Med. 2004 Mar 16;140(6):441-51.

Wootton M. Morphine is not the only analgesic in palliative care: literature review. J Adv Nurs. 2004 Mar;45(5):527-32.

Wulff H, Castle NA, Pardo LA. Voltage-gated potassium channels as therapeutic targets. Nat Rev Drug Discov. 2009 Dec;8(12)

:982-1001. 
Vanegas H, Schaible H. Effects of antagonists to high-threshold calcium channels upon spinal mechanisms of pain, hyperalgesia and allodynia. Pain. 2000 Mar;85(1-2):9-18.

Vanderah TW. Pathophysiology of pain. Med Clin North Am. 2007 Jan;91(1):1-12.

Yaksh TL, Wilson PR. Spinal serotonin terminal system mediates antinociception. J Pharmacol Exp Ther. 1979 Mar;208(3):446-53.

Yaksh TL, Tyce GM. Microinjection of morphine into the periaqueductal gray evokes the release of serotonin from spinal cord. Brain Res. 1979 Jul 27;171(1):176-81.

Yaksh TL. Spinal systems and pain processing: development of novel analgesic drugs with mechanistically defined models. Trends Pharmacol Sci. 1999 Aug;20(8):329-37.

Yan L, Herrington J, Goldberg E, Dulski PM, Bugianesi RM, Slaughter RS, Banerjee P, Brochu RM, Priest BT, Kaczorowski GJ, Rudy B, Garcia ML. Stichodactyla helianthus peptide, a pharmacological tool for studying Kv3.2 channels. Mol Pharmacol. 2005 May;67(5):1513-21.

Yeung SY, Thompson D, Wang Z, Fedida D, Robertson B. Modulation of Kv3 subfamily potassium currents by the sea anemone toxin BDS: significance for CNS and biophysical studies. J Neurosci. 2005 Sep 21;25(38):8735-45.

Zaharenko AJ, Ferreira WA, Jr., de Oliveira JS, Konno K, Richardson M, Schiavon E, Wanke E, de Freitas JC. Revisiting cangitoxin, a sea anemone peptide: Purification and characterization of cangitoxins II and III from the venom of Bunodosoma cangicum. Toxicon. 2008; 51(7):1303-7.

Zaharenko AJ, Ferreira WA, Jr., Oliveira JS, Richardson M, Pimenta DC, Konno K, Portaro FC, de Freitas JC. Proteomics of the neurotoxic fraction from the sea anemone Bunodosoma cangicum venom: Novel peptides belonging to new classes of toxins. Comp Biochem Physiol Part D Genomics Proteomics. 2008 Sep;3(3):219-25.

Zaharenko AJ, Picolo G, Ferreira Jr WA, Murakami T, Kazuma K, Hashimoto M, Cury Y, Freitas JC, Katsuhiro K. Bunodosine 391: a new a acylamino acid from the venom of the sea anemone Bunodosoma cangicum. Journal of Natural Products. 2010. In press. 
Zeitz KP, Guy N, Malmberg AB, Dirajlal S, Martin WJ, Sun L, Bonhaus DW, Stucky CL, Julius D, Basbaum AI. The 5-HT3 subtype of serotonin receptor contributes to nociceptive processing via a novel subset of myelinated and unmyelinated nociceptors. J Neurosci. 2002 Feb 1;22(3):1010-9. 